\title{
Efficient preparation of site-specific antibody-drug conjugates using phosphopantetheinyl transferases
}

Jan Grünewald, ${ }^{*}{ }^{\dagger}$ Heath E. Klock, ${ }^{\dagger}$ Susan E. Cellitti, ${ }^{\dagger}$ Badry Bursulaya, ${ }^{\dagger}$ Daniel McMullan, ${ }^{\dagger}$ David H. Jones, ${ }^{\dagger}$ Hsien-Po Chiu, ${ }^{\dagger}$ Xing Wang, ${ }^{\dagger}$ Paula Patterson, ${ }^{\dagger}$ Huanfang Zhou, ${ }^{\dagger}$ Julie Vance, ${ }^{\dagger}$ Edward Nigoghossian, ${ }^{\dagger}$ Hung Tong, ${ }^{\dagger}$ Dylan Daniel, ${ }^{\ddagger}$ William Mallet, ${ }^{\ddagger}$ Weijia Ou, ${ }^{\dagger}$ Tetsuo Uno, $^{\dagger}$ Ansgar Brock, $^{\dagger}$ Scott A. Lesley, ${ }^{\dagger}$ and Bernhard H. Geierstanger ${ }^{*}{ }^{\dagger}$

${ }^{\dagger}$ Genomics Institute of the Novartis Research Foundation, 10675 John-Jay-Hopkins Drive, San Diego, CA 92121-1125

${ }^{\ddagger}$ Novartis Institutes for BioMedical Research, 4560 Horton Street, Emeryville, CA 94608-2916

${ }^{*}$ To whom correspondence should be addressed.

E-mail: bgeierstanger@gnf.org or jgrunewald@gnf.org.

\section{SI Experimental Procedures}

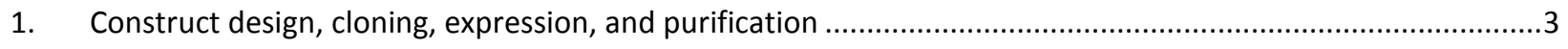

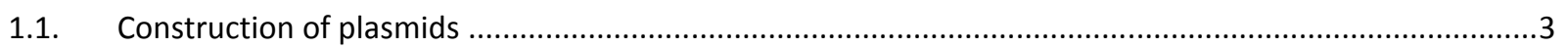

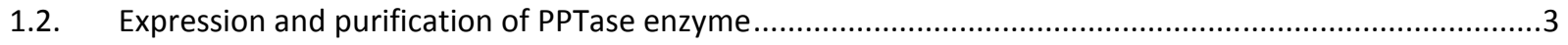

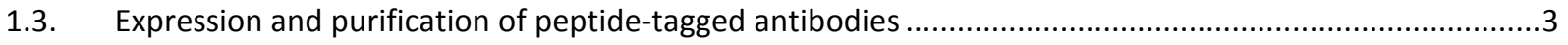

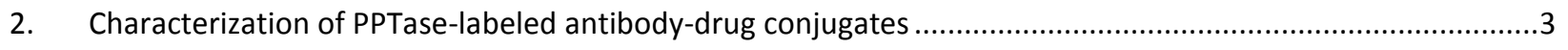

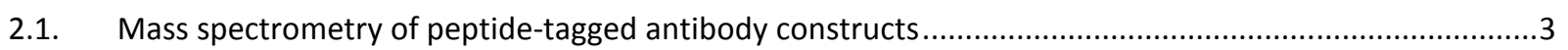

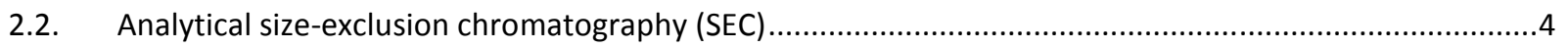

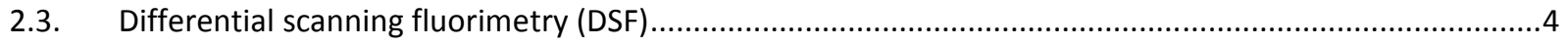

2.4. Mass spectrometric analysis of an ADC purified from terminal bleed serum. ......................................

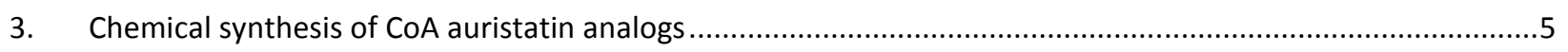

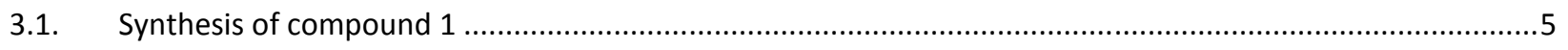

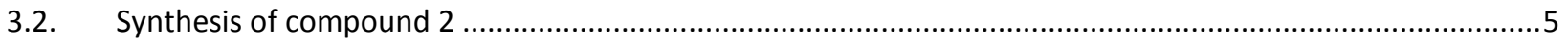

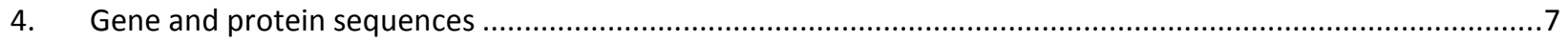




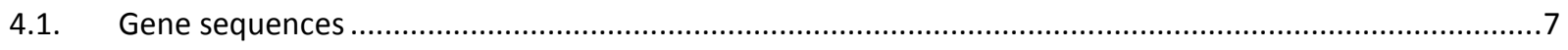

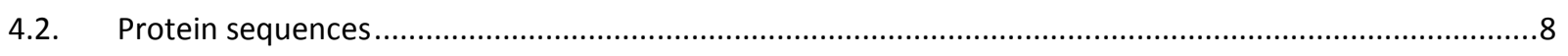

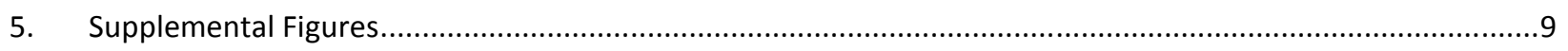

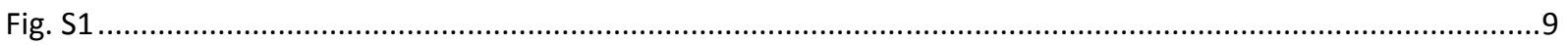

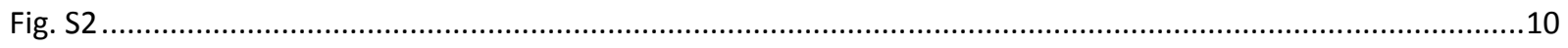

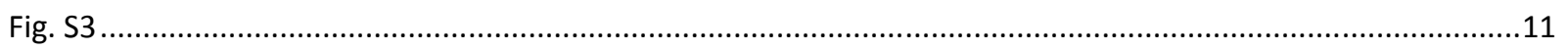

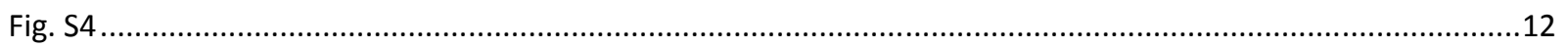

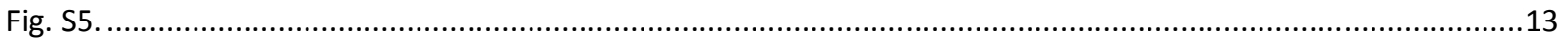

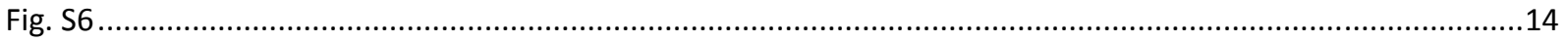

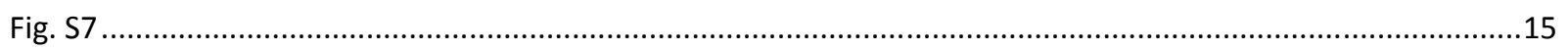

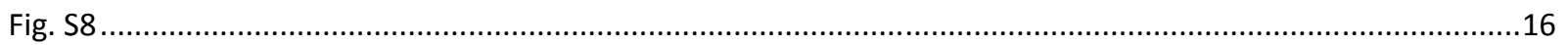

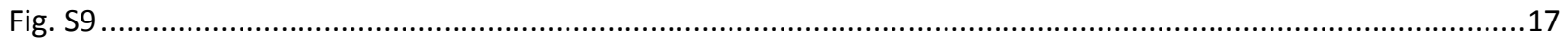

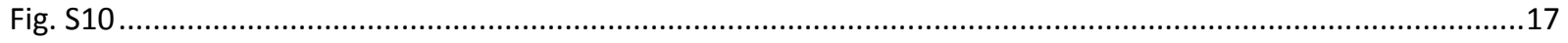

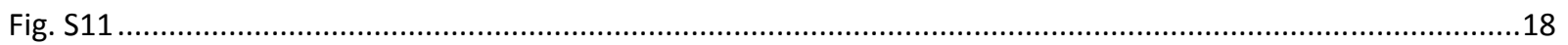

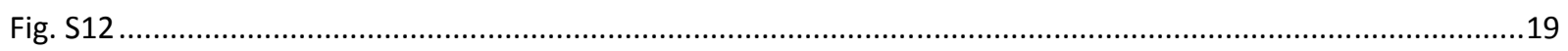

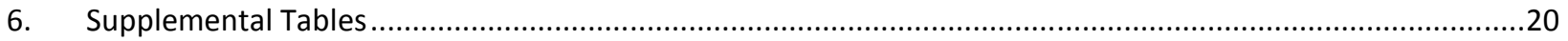

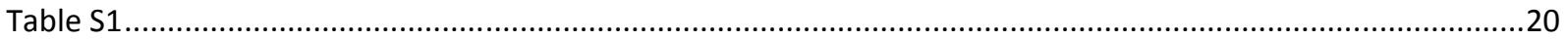

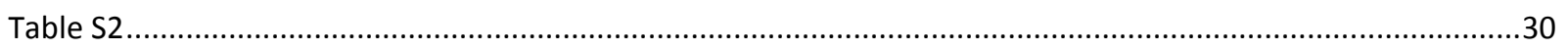

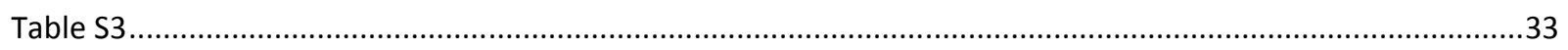

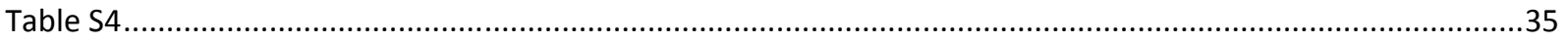

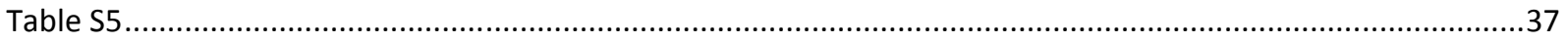

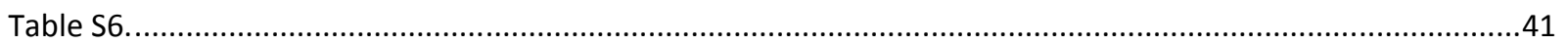

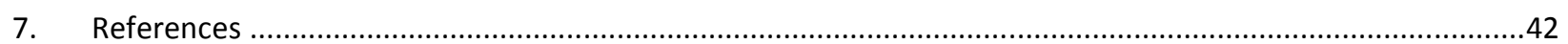




\section{Construct design, cloning, expression, and purification}

1.1. Construction of plasmids. The construction of the plasmid for bacterial expression of $B$. subtilis Sfp phosphopantetheinyl transferase, pET22b-Sfp-TEV-His ${ }_{6}$, was described earlier. ${ }^{1}$ Synthetic DNA fragments encoding the variable region of heavy and light chains of an anti-HER2 antibody ${ }^{2}$ were cloned into two proprietary vectors that encode the constant region of human IgG1 heavy chain and human kappa light chain, respectively. The corresponding mammalian expression plasmids express antiHER2 heavy and light chains under the control of CMV promoters. Both antibody heavy and light chains are preceded by a 24-mer signal peptide (MKTFILLLWVLLLWVIFLLPGATA) to direct their secretion. DNA fragments encoding $\mathrm{S} 6, \mathrm{ybbR}$, and $\mathrm{A} 1$ peptide sequences were incorporated into the constant region of heavy and light chains using the PIPE method. ${ }^{3}$ The same procedure was used to clone $\mathrm{S} 6$ and $\mathrm{ybbR}$ encoding DNA fragments into vectors expressing the mutated heavy chains of mAb1 IgG1 and mAb2 IgG1 under the control of a CMV promoter. DNA fragments encoding heavy and light chains of the ybbR-tagged anti-HER2 antibody, HC-E388-ybbR, were also cloned into vectors suitable for the selection of stably transfected cell clones.

1.2. Expression and purification of PPTase enzyme. The preparation of recombinant Sfp PPTase with TEV-cleavable $\mathrm{His}_{6}$-tag was described previously. ${ }^{1}$

1.3. Expression and purification of peptide-tagged antibodies. Culturing and transient transfection of HEK293F cells was carried out as described previously ${ }^{4}$ using plasmid DNA encoding heavy and light chains of trastuzumab (IgG1 kappa). Five days after transfection, cell cultures were harvested by centrifugation at $2,000 \times \mathrm{g}$ for $30 \mathrm{~min}$ at $4^{\circ} \mathrm{C}$. After passing the culture medium supernatant through a $0.22 \mu \mathrm{m}$ filter, affinity purification was performed using rmp Protein A Sepharose Fast Flow (GE Healthcare, Piscataway, NJ). Specifically, the cleared medium supernatant was loaded with a flowrate of $0.5-1 \mathrm{~mL} / \mathrm{min}$ onto the PBS-equilibrated affinity medium. Unbound protein was washed off with PBS. IgG elution was carried out with 5-10 column volumes of $0.1 \mathrm{M}$ sodium acetate (pH 3.0) followed by immediate neutralization with $1 \mathrm{M}$ Tris buffer $(\mathrm{pH}$ 8-10). Depending on the downstream application, eluted IgG was either dialyzed into PBS or conjugation buffer $(75 \mathrm{mM}$ Tris/ $\mathrm{HCl}$ (pH 8.0), $20 \mathrm{mM} \mathrm{NaCl}, 12.5 \mathrm{mM} \mathrm{MgCl}$ ) via 3.5 or $7.0 \mathrm{kDa}$ cut-off Slide-A-Lyzer Dialysis Cassettes (Life Technologies, Carlsbad, CA). Antibody yields were quantitated by Bradford assay or by absorbance measurements at $280 \mathrm{~nm}$ on a ND-1000 UV-Vis spectrophotometer (NanoDrop Technologies, Wilmington, DE). Protein purity was assessed by SDS-PAGE.

Small scale expressions of peptide-tagged anti-HER2 antibodies in $35 \mathrm{~mL}$ culture medium were performed using the Protein Expression and Purification Platform (PEPP). ${ }^{5}$ This automated system was also used for subsequent protein A affinity purification.

\section{Characterization of PPTase-labeled antibody-drug conjugates}

2.1. Mass spectrometry of peptide-tagged antibody constructs. Prior to mass spectrometric analysis, peptide-tagged antibodies or ADCs were concentrated using $30 \mathrm{kDa}$ cut-off Amicon Ultra centrifugal filters (EMD Millipore, Billerica, MA). Next, $20 \mu \mathrm{L}$ of the concentrated solution was supplemented with $5 \mu \mathrm{L}$ of $0.1 \mathrm{M}$ Tris buffer $(\mathrm{pH} 8)$. Antibody deglycosylation was accomplished by addition of $1 \mu \mathrm{g}$ of PNGase $\mathrm{F}$ followed by incubation for $12-16 \mathrm{~h}$ at $37^{\circ} \mathrm{C}$. The deglycosylated antibodies were further reduced in the presence of approximately $20 \mathrm{mM}$ of TCEP. After incubation for 
about 15 min at $23^{\circ} \mathrm{C}$, LC-MS was performed using a reversed-phase trap cartridge (MicroTrap ${ }^{\mathrm{TM}}$, Michrom Bioresources, Auburn, CA). Elution into the ESI source of the LC-MS system, consisting of a capillary LC with auto-sampler and a Q-TOF 2 (Waters, Milford, MA) or Agilent 6520 Q-TOF (Agilent Technologies, Folsom, CA) mass spectrometer was carried out using a step gradient of $80 \%$ acetonitrile $/ 0.2 \%$ formic acid at a flowrate of $5 \mu \mathrm{L} / \mathrm{min}$ after loading and desalting the sample with $0.2 \%$ formic acid in water. Summing, smoothing, and chargestate deconvolution of the resulting spectra was performed using the MassLynx ${ }^{\mathrm{TM}}$ software package (Waters).

2.2. Analytical size-exclusion chromatography (SEC). Analytical SEC was performed using a 1525 Binary HPLC Pump (Waters) equipped with a Shodex KW-G guard column $(7 \mu \mathrm{m}, 50 \times 6 \mathrm{~mm}$, Thomson Instrument Company, Oceanside, CA), which was connected to a Shodex PROTEIN KW-803 column ( $5 \mu \mathrm{m}, 300 \times 8 \mathrm{~mm}$, Thomson Instrument Company). Equilibration was performed with mobile phase containing $20 \mathrm{mM}$ Tris buffer ( $\mathrm{pH} \sim 7.7), 200 \mathrm{mM} \mathrm{NaCl}$, and $0.02 \%(\mathrm{w} / \mathrm{v})$ sodium azide. Prior to sample injection, the instrument was calibrated using a Bio-Rad Gel Filtration Standard (Bio-Rad Laboratories, Hercules, CA). Injection of $25 \mu \mathrm{L}$ of $0.5 \mathrm{mg} / \mathrm{mL}$ of peptide-tagged ADC was followed by isocratic elution over $15 \mathrm{~min}$ and monitoring at $280 \mathrm{~nm}$. Data processing was performed using the MassLynx ${ }^{\mathrm{TM}}$ software package (Waters).

2.3. Differential scanning fluorimetry (DSF). DSF measurements were carried out at an antibody/ADC concentration of $0.25 \mathrm{mg} / \mathrm{mL}(1.67 \mu \mathrm{M})$ in PBS $(\mathrm{pH} 7.4)$. SYPRO Orange Protein Gel Stain (Sigma-Aldrich, St. Louis, $\mathrm{MO}$ ) was added to a final concentration of $5 \mathrm{x}$ and melting curves were obtained by heating the sample with twenty fluorescence scans per degree Celsius in a LightCycler 480 Instrument II (Roche Life Science, Indianapolis, IN). Melting transitions were calculated by using the LightCycler 480 software package assuming a 3-state model.

2.4. Mass spectrometric analysis of an ADC purified from terminal bleed serum. In order to determine the drug retention of a PPTase-labeled ADC post-dosing, the respective immunoconjugate was affinity-purified from terminal bleed serum and subjected to mass spectrometric analysis. In a typical experiment, $200 \mu \mathrm{L}$ of murine plasma was diluted with the same volume of PBS supplemented with $10 \mathrm{mM}$ EDTA. Ten $\mu \mathrm{L}$ of $50 \%$ slurry of IgSelect (GE Healthcare) was added to the diluted plasma, followed by incubation under mild agitation for $1 \mathrm{~h}$ at room temperature. After washing the affinity resin twice with $200 \mu \mathrm{L}$ PBS, the sample was eluted off the resin with $2 \times 20 \mu \mathrm{L}$ of $1 \%$ formic acid. The sample was reduced by supplementing the combined eluates with $20 \mu \mathrm{L}$ of $6 \mathrm{M}$ guanidine hydrochloride solution and $5 \mu \mathrm{L}$ of $0.66 \mathrm{M}$ TCEP in $3.3 \mathrm{M}$ ammonium acetate buffer ( $\mathrm{pH} 5$ ), followed by incubation for at least $30 \mathrm{~min}$ at room temperature. Next, mass spectrometry was performed on an Agilent Technologies 6550-iFunnel QTOF MS / Agilent 1260 HPLC system. For this purpose, the sample was desalted using a PLRS column ( $8 \mu \mathrm{m}, 2.1 \times 50 \mathrm{~mm}, 1000 \AA$, Agilent Technologies) at a flow rate of 0.5 $\mathrm{mL} / \mathrm{min}$ at $80^{\circ} \mathrm{C}$. Sample elution was performed by applying a 6 -min gradient from $20 \%$ to $60 \%$ acetonitrile containing $0.1 \%$ formic acid. Processing of the spectral record and spectral deconvolution was carried out using Agilent Qualitative Analysis Software. The average drug-to-antibody ratio (DAR) was calculated using the relative peak heights of all conjugation states across a distribution. 


\section{Chemical synthesis of CoA auristatin analogs}

\subsection{Synthesis of compound 1}<smiles>CC(C)(COP(=O)(O)OP(=O)(O)OCC1OC(n2cnc3c(N)ncnc32)C(O)C1OP(=O)(O)O)C(O)C(=O)NCCC(=O)NCCS</smiles><smiles>CCC(C)C(=O)CC(CC)N(C)C(=O)C(NC(=O)C(C(C)C)N(C)C(=O)CCCCCN1C(=O)CC(SCCNC(=O)CCNC(=O)C(O)C(C)(C)COP(=O)(O)P(=O)(O)OP(=O)(O)O)C1=O)C(C)C</smiles>

Maleimidocaproyl-monomethylauristatin $\mathrm{F}^{6}(36.0 \mathrm{mg}, 38.9 \mu \mathrm{mol})$ dissolved in $1.8 \mathrm{~mL}$ of DMSO was added to CoA ( $39.0 \mu \mathrm{mol}$ in $312 \mu \mathrm{L}$ water) in $2.9 \mathrm{~mL}$ of $10 \times \mathrm{PBS}$ and stirred at $23^{\circ} \mathrm{C}$ for $1 \mathrm{~h}$. After the reaction, the reaction mixture was lyophilized to obtain the crude material, which was purified by RP- $\mathrm{C}_{18}$ flash chromatography. Fractions of the desired product were combined and lyophilized to afford $\mathbf{1}$ (35.5 mg with $97.5 \%$ purity) as a white powder. ESI-MS calculated for $\mathrm{C}_{70} \mathrm{H}_{112} \mathrm{~N}_{13} \mathrm{O}_{27} \mathrm{P}_{3} \mathrm{~S}[\mathrm{MH}]^{+}: 1691.7$; observed: 1691.2 .

\subsection{Synthesis of compound 2}

Synthesis of maleimidohexyl-monomethylauristatin $\mathrm{F}$<smiles>COC(=O)N1C(=O)C=CC1=O</smiles>

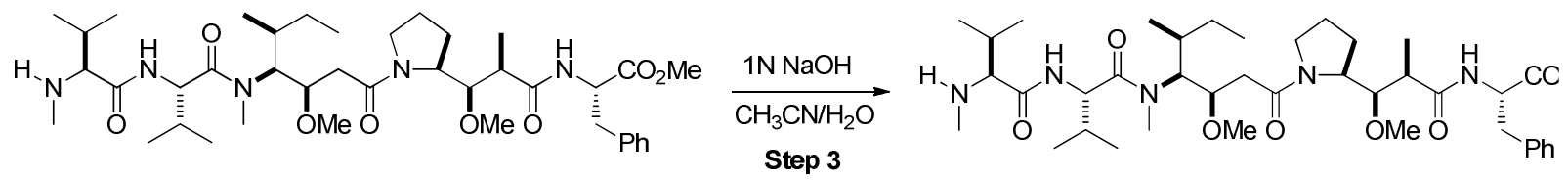<smiles>CC1C(=O)C=CC1=O</smiles>

$\mathrm{NaBH}_{3} \mathrm{CN}, \mathrm{MeOH}$

Step 4<smiles>CC[C@H](C)[C@@H](C(CC(=O)N1CCCC1[C@H](OC)[C@@H](C)C(=O)N[C@H](Cc1ccccc1)C(=O)O)OC)N(C)C(=O)[C@H](NC(=O)C(C(C)C)N(C)CCCCCN1C(=O)C=CC1=O)C(C)C</smiles> 
Step 1: To a $100 \mathrm{~mL}$ round-bottom flask was added 6-amino-1-hexanol (1.0 g, $6.44 \mathrm{mmol})$ in saturated $\mathrm{NaHCO}_{3}(12 \mathrm{~mL})$ aqueous solution. The mixture was cooled down to $0^{\circ} \mathrm{C}$, followed by addition of $\mathrm{N}$ methoxycarbonyl-maleimide $(0.75 \mathrm{~g}, 6.44 \mathrm{mmol})$. After stirring at $0^{\circ} \mathrm{C}$ for 1.5 hours, the mixture was quenched at $0^{\circ} \mathrm{C}$ with $\mathrm{HCl}(2 \mathrm{M})$ until the $\mathrm{pH}$ reached 1. Following extraction with AcOEt, the organic phase was concentrated. The residue was dissolved in DCM and purified by ISCO. Elution was performed with MeOH/DCM (0-4\%) to obtain 1-(6-hydroxyhexyl)-1H-pyrrole-2,5-dione as a white solid (970 mg, 76\% yield). ${ }^{1} \mathrm{H}$ NMR $\left(400 \mathrm{MHz}, \mathrm{CDCl}_{3}\right): \delta 6.68(\mathrm{~s}, 2 \mathrm{H}), 3.63(\mathrm{t}, \mathrm{d}=6.4 \mathrm{~Hz}, 2 \mathrm{H}), 3.52(\mathrm{t}, \mathrm{d}=7.2 \mathrm{~Hz}$, $2 \mathrm{H}), 1.63-1.52(\mathrm{~m}, 4 \mathrm{H}), 1.43-1.28(\mathrm{~m}, 4 \mathrm{H})$. ESI-MS calculated for $\mathrm{C}_{10} \mathrm{H}_{16} \mathrm{NO}_{3}[\mathrm{MH}]^{+}:$198.1; observed 198.2 .

Step 2: 1-(6-hydroxyhexyl)-1H-pyrrole-2,5-dione (236.6 mg, $1.2 \mathrm{mmol}$ ) was dissolved in DCM (10 mL). The solution was supplemented with Dess-Martin reagent $(610.7 \mathrm{mg}, 1.44 \mathrm{mmol})$. After 1 hour at room tempterature, the reaction was diluted with DCM $(10 \mathrm{~mL})$ and filtered. The filtrate was concentrated and purified by ISCO. Elution was carried out with EtOAC/Hexane $0-20 \%$ to afford 6-(2,5-dioxo-2,5dihydro-1H-pyrrol-1-yl)hexanal as a colorless oil (180 mg, 76\% yield). ${ }^{1} \mathrm{H} \mathrm{NMR}\left(400 \mathrm{MHz}, \mathrm{CDCl}_{3}\right): \delta 9.76$ $(t, d=1.6 \mathrm{~Hz}, 1 \mathrm{H}), 6.69(\mathrm{~s}, 2 \mathrm{H}), 3.52(\mathrm{t}, \mathrm{d}=7.2 \mathrm{~Hz}, 2 \mathrm{H}), 2.43(\mathrm{td}, \mathrm{d}=7.2 \mathrm{~Hz}, 1.6 \mathrm{~Hz}, 2 \mathrm{H}), 1.70-1.56(\mathrm{~m}, 4 \mathrm{H})$, 1.36-1.28 (m, 2H). ESI-MS calculated for $\mathrm{C}_{10} \mathrm{H}_{14} \mathrm{NO}_{3}[\mathrm{MH}]^{+}:$196.1; observed 196.2.

Step 3: Monomethylauristatin F-OMe $(78 \mathrm{mg}, 104 \mu \mathrm{mol})$ was dissolved in acetonitrile $(0.5 \mathrm{~mL})$ and $\mathrm{H}_{2} \mathrm{O}$ $(0.32 \mathrm{~mL})$ followed by addition of $\mathrm{NaOH}(1 \mathrm{~N}, 0.25 \mathrm{~mL})$. After 1 hour at room temperature, more acetonitrile $(0.25 \mathrm{~mL}), \mathrm{H}_{2} \mathrm{O}(0.16 \mathrm{~mL})$ and $\mathrm{NaOH}(1 \mathrm{~N}, 0.125 \mathrm{~mL})$ was added. After $30 \mathrm{~min}$, the reaction was neutralized with $1 \mathrm{~N} \mathrm{HCl}$ until the $\mathrm{pH}$ reached 7. The mixture was lyophilized to afford crude monomethylauristatin F-OH (100 mg). ESI-MS calculated for $\mathrm{C}_{39} \mathrm{H}_{66} \mathrm{~N}_{5} \mathrm{O}_{8}[\mathrm{MH}]^{+}:$732.5; observed 732.5. Step 4: Monomethylauristatin F-OH from last step (104 $\mu \mathrm{mol})$ was dissolved in $\mathrm{MeOH}(4 \mathrm{~mL})$. 6-(2,5dioxo-2,5-dihydro-1H-pyrrol-1-yl)hexanal $(60.8 \mathrm{mg}, 311 \mu \mathrm{mol})$ was added. Then $\mathrm{NaBH}_{3} \mathrm{CN}(104.6 \mathrm{mg}$, $1.66 \mathrm{mmol}$ ) was added. After $30 \mathrm{~min}$ at room temperature, more $\mathrm{NaBH}_{3} \mathrm{CN}(52.3 \mathrm{mg}, 0.83 \mathrm{mmol})$ was added. After $15 \mathrm{~min}$, the reaction was stopped and purified by preparative HPLC to afford maleimidohexyl-monomethylauristatin $\mathrm{F}$ (50.4 mg, 53\% yield). ESI-MS calculated for $\mathrm{C}_{49} \mathrm{H}_{79} \mathrm{~N}_{6} \mathrm{O}_{10}[\mathrm{MH}]^{+}$: 911.6; observed 911.6. 
Synthesis of CoA-maleimidohexyl-monomethylauristatin F (compound 2)

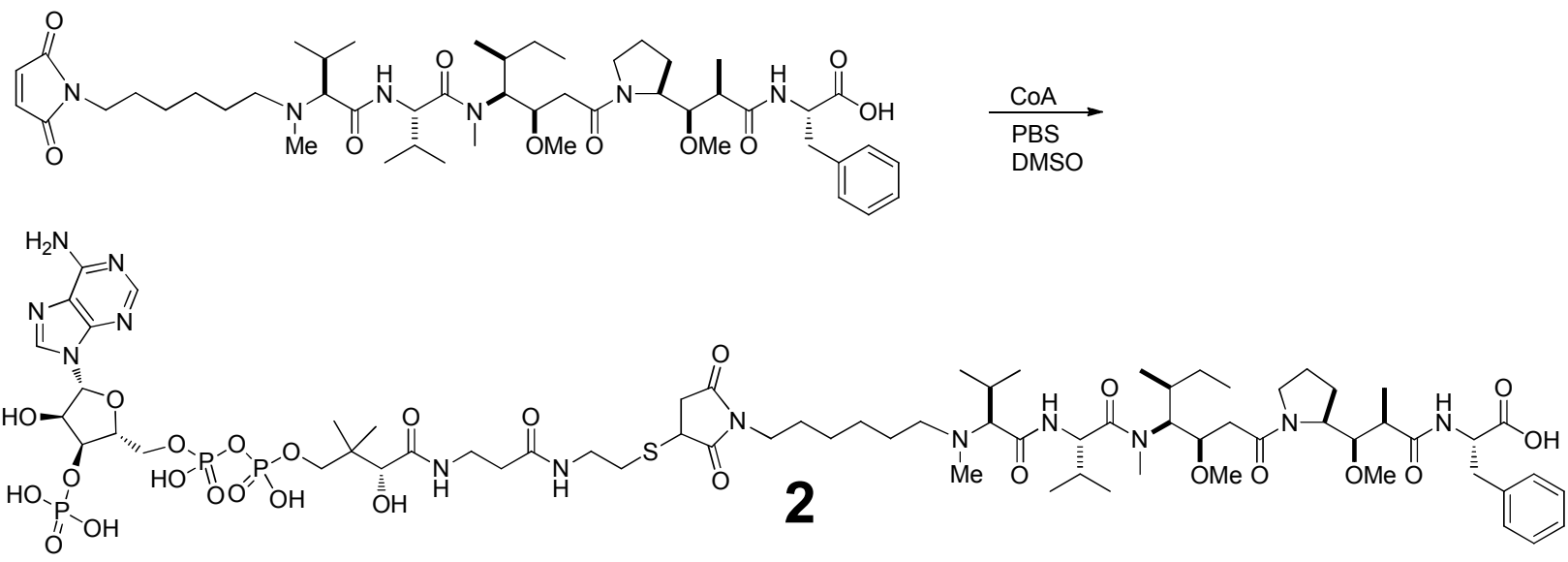

Maleimidohexyl-monomethylauristatin F (18 mg, $19.8 \mu \mathrm{mol})$ was dissolved in DMSO $(1.38 \mathrm{~mL})$ and PBS $(12.3 \mathrm{~mL})$. CoA (125 mM, $158 \mu \mathrm{L}, 19.8 \mu \mathrm{mol})$ was added. After $30 \mathrm{~min}$ at room temperature, the reaction mixture was lyophilized to obtain the crude product, which was purified by RP-C18aq SPE. Fractions of the desired product were combined and lyophilized to afford $\mathbf{2}$ ( $23.8 \mathrm{mg}, 72 \%$ yield). ESI-MS calculated for $\mathrm{C}_{70} \mathrm{H}_{115} \mathrm{~N}_{13} \mathrm{O}_{26} \mathrm{P}_{3} \mathrm{~S}[\mathrm{MH}]^{+}$: 1678.7; observed: 1679.6 .

\section{Gene and protein sequences}

\subsection{Gene sequences}

Anti-HER2 (trastuzumab) heavy chain (with $\mathrm{N}$-terminal signal peptide) atgaaaacattcatactcctgctctgggtactgctgctctgggttatcttcctgcttcccggtgccactgctgaggttcagctggtggagtctggcggtgg cctggtgcagccagggggctcactccgtttgtcctgtgcagcttctggcttcaacattaaagacacctatatacactgggtgcgtcaggccccgggtaa gggcctggaatgggttgcaaggatttatcctacgaatggttatactagatatgccgatagcgtcaagggccgtttcactataagcgcagacacatcca aaaacacagcctacctgcagatgaacagcctgcgtgctgaggacactgccgtctattattgttctagatggggaggggacggcttctatgctatggact actggggtcaaggaaccctggtcaccgtctcctcggctagcaccaagggccccagcgtgttccccctggcccccagcagcaagagcaccagcggcgg cacagccgccctgggctgcctggtgaaggactacttccccgagcccgtgaccgtgtcctggaacagcggagccctgacctccggcgtgcacaccttcc ccgccgtgctgcagagcagcggcctgtacagcctgtccagcgtggtgacagtgcccagcagcagcctgggcacccagacctacatctgcaacgtgaa ccacaagcccagcaacaccaaggtggacaagaaagtggagcccaagagctgcgacaagacccacacctgccccccctgcccagccccagagctgc tgggcggaccctccgtgttcctgttcccccccaagcccaaggacaccctgatgatcagcaggacccccgaggtgacctgcgtggtggtggacgtgagc cacgaggacccagaggtgaagttcaactggtacgtggacggcgtggaggtgcacaacgccaagaccaagcccagagaggagcagtacaacagca cctacagggtggtgtccgtgctgaccgtgctgcaccaggactggctgaacggcaaggaatacaagtgcaaggtctccaacaaggccctgccagcccc catcgaaaagaccatcagcaaggccaagggccagccacgggagccccaggtgtacaccctgcccccctcccgggaggagatgaccaagaaccagg tgtccctgacctgtctggtgaagggcttctaccccagcgacatcgccgtggagtgggagagcaacggccagcccgagaacaactacaagaccacacc tccagtgctggacagcgacggcagcttcttcctgtacagcaagctgaccgtggacaagtccaggtggcagcagggcaacgtgttcagctgcagcgtg atgcacgaggccctgcacaaccactacacccagaagagcctgagcctgtcccccggcaagtaa

\section{Anti-HER2 (trastuzumab) light chain (with $\mathbf{N}$-terminal signal peptide)} atgaaaacattcatactcctgctctgggtactgctgctctgggttatcttcctgcttcccggtgccactgctgatatccagatgacccagtccccgagctc cctgtccgcctctgtgggcgatagggtcaccatcacctgccgtgccagtcaggatgtgaatactgctgtagcctggtatcaacagaaaccaggaaaag ctccgaaactactgatttactcggcatccttcctctactctggagtcccttctcgcttctctggatccagatctgggacggatttcactctgaccatcagca 
gtctgcagccggaagacttcgcaacttattactgtcagcaacattatactactcctcccacgttcggacagggtaccaaggtggagatcaaacgaacg gtggccgctcccagcgtgttcatcttccccccagcgacgagcagctgaagagcggcaccgccagcgtggtgtgcctgctgaacaacttctacccccg ggaggccaaggtgcagtggaaggtggacaacgccctgcagagcggcaacagccaggagagcgtcaccgagcaggacagcaaggactccacctac agcctgagcagcaccctgaccctgagcaaggccgactacgagaagcataaggtgtacgcctgcgaggtgacccaccagggcctgtccagccccgtg accaagagcttcaacaggggcgagtgctaa

\section{B. subtilis Sfp (with TEV-cleavable C-terminal $\mathrm{His}_{6}$-tag)}

atgaaaatttatgggatttacatggatcgcccgctctcgcaggaagaaaatgaacgcttcatgtctttcatttcaccagagaaacgcgaaaaatgccgt cgcttctaccataaagaagatgctcaccgcaccctgctgggagatgtgctggtgcgtagtgtaatcagccgtcaatatcaactggacaaaagcgacat ccgttttagcacgcaggaatatggcaaaccgtgcattccagatcttccagatgcccactttaacattagccatagcggtcgttgggtgatctgcgccttt gattcccagccgatcggaatcgacatcgaaaagaccaaacctatctcattggaaattgccaaacgttttttctccaagaccgaatattccgatctgctc gccaaagacaaagatgaacagacggattacttttaccatctgtggagcatgaaagaaagtttcatcaaacaggagggcaaaggtctttctttacccct ggatagtttctcagtccgcctgcaccaagatggccaggtctcaattgaacttccggattcccattctccctgctacatcaagacatatgaggtggacccg ggctacaaaatggctgtttgtgcagcgcacccagatttcccggaggatatcacgatggtctcctatgaagaattgctggagaacctgtacttccaaggc caccaccaccaccaccactga

\subsection{Protein sequences}

Anti-HER2 (trastuzumab) heavy chain (with $\mathbf{N}$-terminal signal peptide). MKTFILLLWVLLLWVIFLLPGATAEVQLVESGGGLVQPGGSLRLSCAASGFNIKDTYIHWVRQAPGKGLEWVARIYPTN GYTRYADSVKGRFTISADTSKNTAYLQMNSLRAEDTAVYYCSRWGGDGFYAMDYWGQGTLVTVSSASTKGPSVFPLA PSSKSTSGGTAALGCLVKDYFPEPVTVSWNSGALTSGVHTFPAVLQSSGLYSLSSVVTVPSSSLGTQTYICNVNHKPSNT KVDKKVEPKSCDKTHTCPPCPAPELLGGPSVFLFPPKPKDTLMISRTPEVTCVVVDVSHEDPEVKFNWYVDGVEVHNAK TKPREEQYNSTYRVVSVLTVLHQDWLNGKEYKCKVSNKALPAPIEKTISKAKGQPREPQVYTLPPSREEMTKNQVSLTCL VKGFYPSDIAVEWESNGQPENNYKTTPPVLDSDGSFFLYSKLTVDKSRWQQGNVFSCSVMHEALHNHYTQKSLSLSPG $\mathrm{K}$

$=$ Signal peptide for secretion

$=\mathrm{V}_{\mathrm{H}}$ domain

$=\mathrm{CH} 1$ domain

$=\mathrm{CH} 2$ domain

$=\mathrm{CH} 3$ domain

Anti-HER2 (trastuzumab) light chain (with $\mathbf{N}$-terminal signal peptide). MKTFILLLWVLLLWVIFLLPGATADIQMTQSPSSLSASVGDRVTITCRASQDVNTAVAWYQQKPGKAPKLLIYSASFLYS GVPSRFSGSRSGTDFTLTISSLQPEDFATYYCQQHYTTPPTFGQGTKVEIKRTVAAPSVFIFPPSDEQLKSGTASVVCLLNN FYPREAKVQWKVDNALQSGNSQESVTEQDSKDSTYSLSSTLTLSKADYEKHKVYACEVTHQGLSSPVTKSFNRGEC

$=$ Signal peptide for secretion

$=\mathrm{V}_{\mathrm{L}}$ domain

$=\mathrm{C}_{\mathrm{L}}$ domain

B. subtilis Sfp (with TEV-cleavable C-terminal His $_{6}$-tag). The TEV protease cleavage site is underlined. MKIYGIYMDRPLSQEENERFMSFISPEKREKCRRFYHKEDAHRTLLGDVLVRSVISRQYQLDKSDIRFSTQEYGKPCIPDL PDAHFNISHSGRWVICAFDSQPIGIDIEKTKPISLEIAKRFFSKTEYSDLLAKDKDEQTDYFYHLWSMKESFIKQEGKGLSLP LDSFSVRLHQDGQVSIELPDSHSPCYIKTYEVDPGYKMAVCAAHPDFPEDITMVSYEELLENLYFQGHHHHHH 


\section{Supplemental Figures}
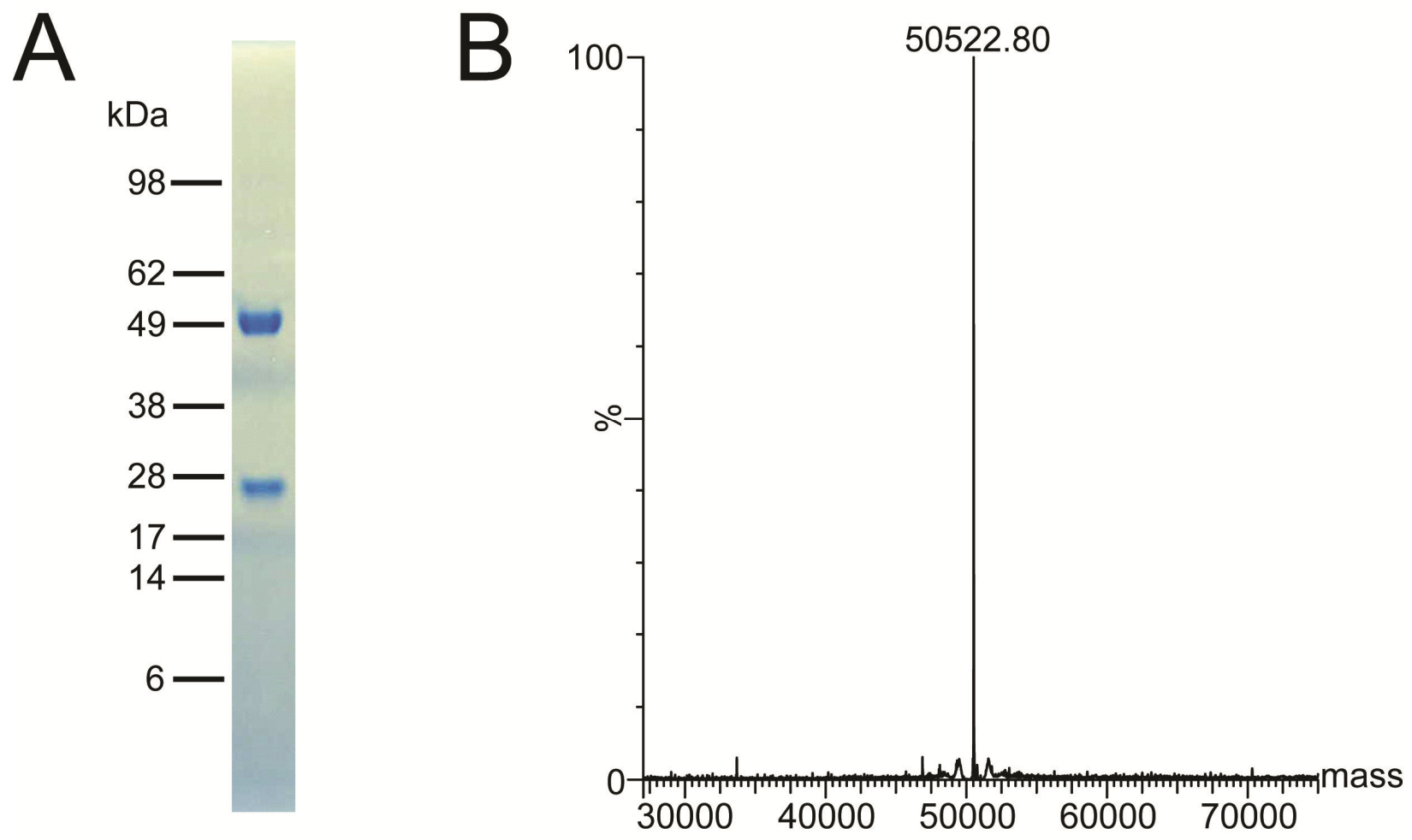

Fig. S1. Characterization of HC-E388-S6 by SDS-PAGE and mass spectrometry. (A) SDS-PAGE analysis of HC-E388-S6 (heavy chain contains N-linked glycans) under reducing conditions with $10 \mathrm{mM} \beta$ -

mercaptoethanol. (B) Charge-state-deconvoluted ESI-MS spectrum confirms insertion of the S6 peptide sequence (GDSLSWLLRLLN) into the heavy chain (lacking N-linked glycans) of anti-HER2 IgG1 kappa (trastuzumab). Calculated molecular weight of HC-E388-S6 is 50525.0 Da. 

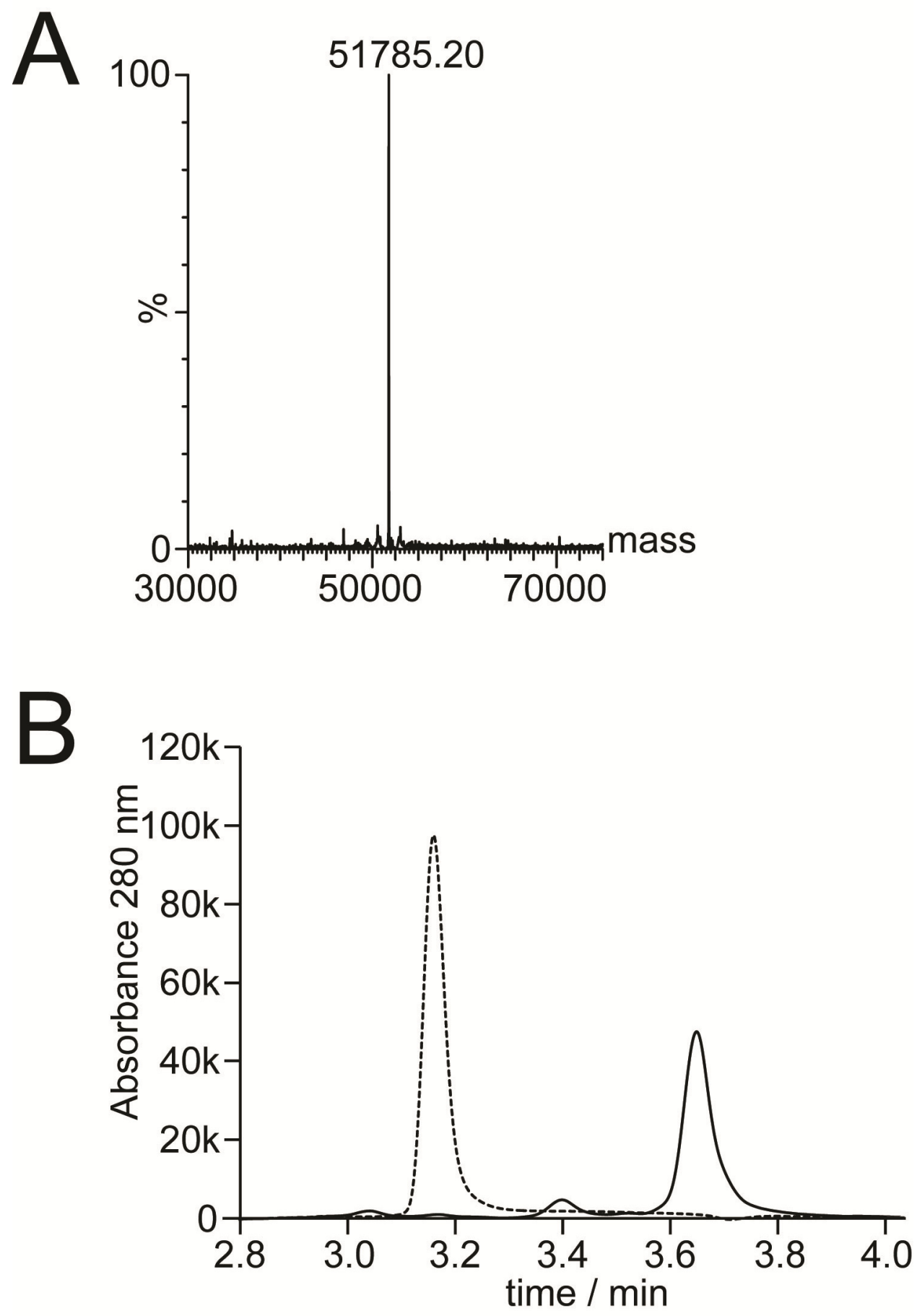

Fig. S2. Sfp PPTase accepts CoA analog 1 as a substrate for site-specific antibody labeling. Conjugation of HC-E388-S6 with 1 was confirmed by ESI-MS (A) and further verified by reverse-phase HPLC (B), which was performed using the respective enzymatic conjugation reaction (solid trace) or uncoupled HC-E388S6 (dashed trace). Calculated molecular weights of HC-E388-S6 and HC-E388-S6-1 are 50525.0 Da and $51790.5 \mathrm{Da}$, respectively. 

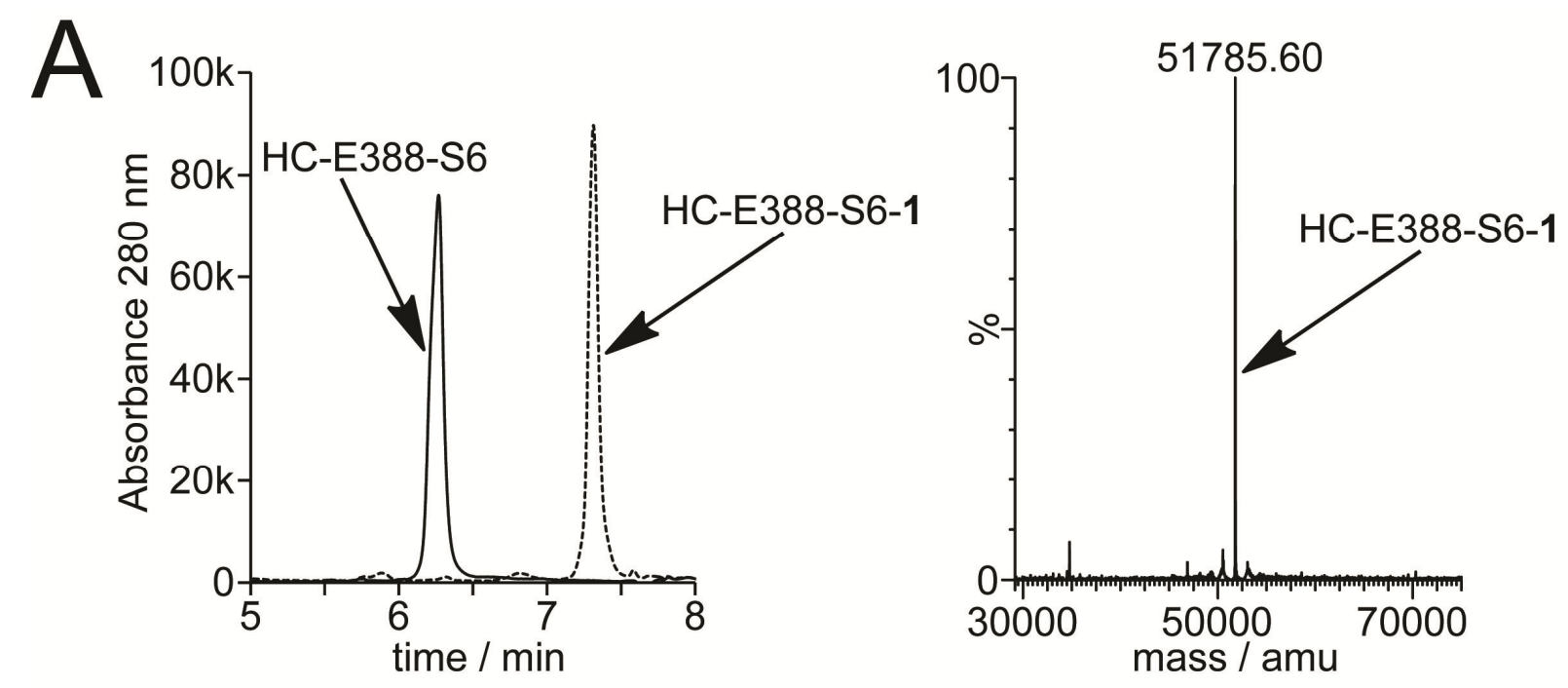

B
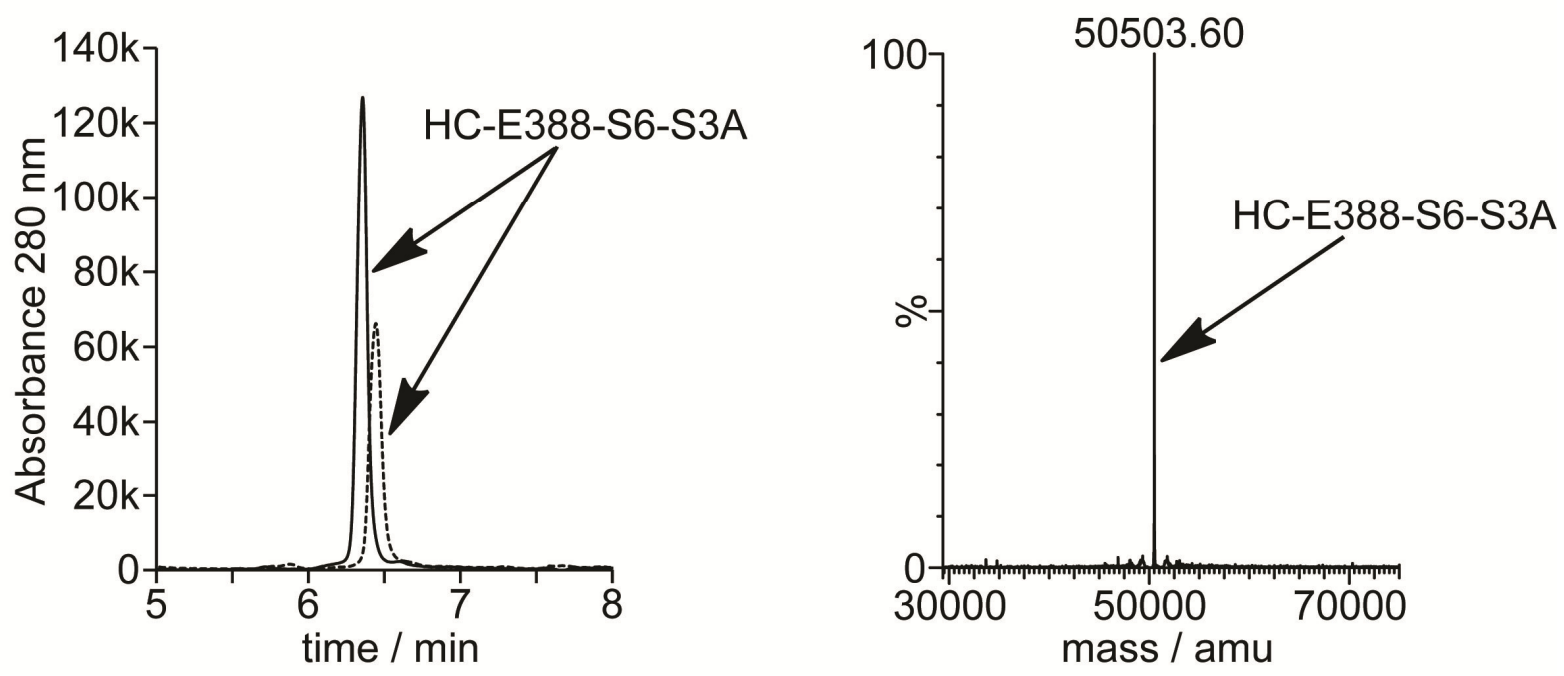

Fig. S3. PPTase-catalyzed antibody labeling is site-specific. (A) On the left side are shown the reversephase HPLC traces of HC-E388-S6 before (solid trace) and after (dashed trace) incubation with $40 \mu \mathrm{M}$ of 1 in the presence of $1 \mu \mathrm{M}$ of Sfp PPTase. Mass spectrometric analysis of the enzyme-containing reaction indicates formation of HC-E388-S6-1. Calculated molecular weights of HC-E388-S6 and HC-E388-S6-1 are 50525.0 Da and 51790.5 Da, respectively. (B) On the left side are shown the reverse-phase HPLC traces of HC-E388-S6-S3A before (solid trace) and after (dashed trace) incubation with $40 \mu \mathrm{M}$ of 1 in the presence of $1 \mu \mathrm{M}$ of Sfp PPTase. The enzyme-containing reaction was further analyzed by mass spectrometry, indicating no labeling of the heavy chain (right side). Calculated molecular weights of HCE388-S6-S3A and HC-E388-S6-S3A-1 are 50509.0 Da and 51774.5 Da, respectively. 

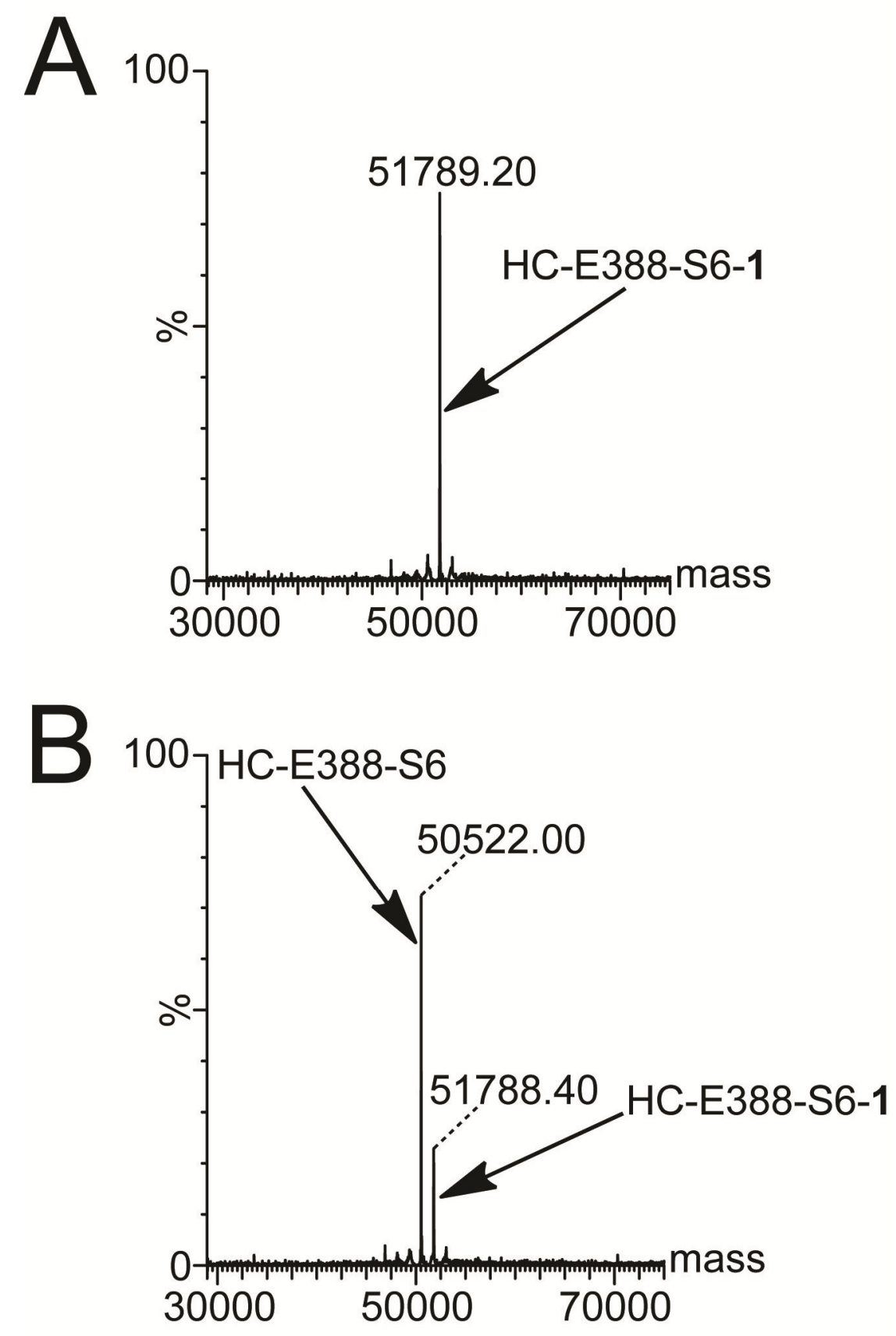

Fig. S4. $0.25 \mu \mathrm{M}$ of Sfp PPTase suffices to label an S6-tagged antibody with two molecules of compound 1. (A) Charge-state-deconvoluted ESI-MS spectrum of a reaction containing $0.25 \mu \mathrm{M}$ Sfp PPTase, $2.5 \mu \mathrm{M}$ HC-E388-S6, and $50 \mu \mathrm{M}$ compound 1 indicates quantitative formation of a DAR 2 ADC. (B) Charge-statedeconvoluted ESI-MS spectrum of a reaction containing $0.1 \mu \mathrm{M}$ Sfp PPTase, $2.5 \mu \mathrm{M}$ HC-E388-S6, and 50 $\mu \mathrm{M}$ compound $\mathbf{1}$ indicates only partial drug conjugation under these conditions. Both reactions were performed for $16 \mathrm{~h}$ at $37^{\circ} \mathrm{C}$ in $50 \mathrm{mM}$ HEPES buffer ( $\mathrm{pH} 7.5$ ) supplemented with $10 \mathrm{mM} \mathrm{MgCl}_{2}$. Calculated molecular weights of HC-E388-S6 and HC-E388-S6-1 are 50525.0 Da and 51790.5 Da, respectively. 


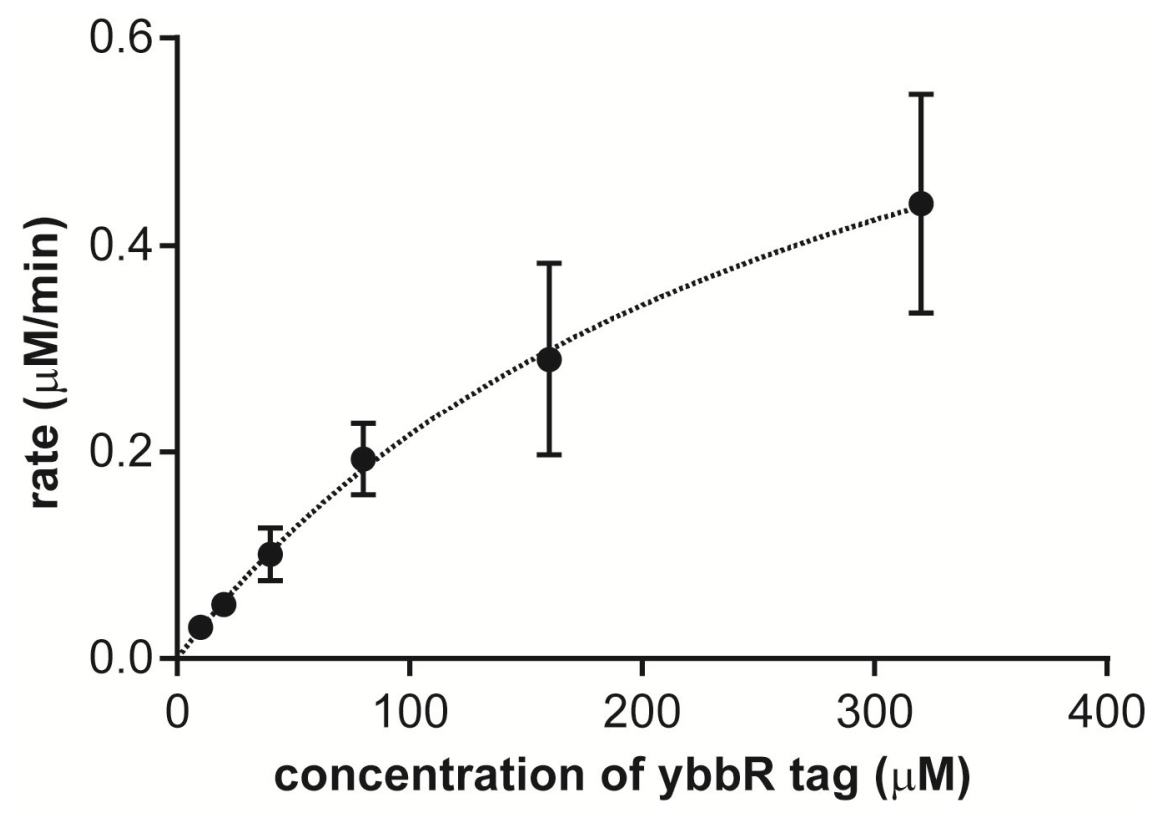

Fig. S5. Kinetic analysis of Sfp-catalyzed conjugation of ybbR-tagged antibody, HC-E388-ybbR, with compound 1. The kinetic parameters, $\mathrm{k}_{\mathrm{cat}}$ and $\mathrm{K}_{\mathrm{m}}$, of the inserted ybbR tag (two ybbR tags per antibody) were determined by curve fitting of a Michaelis-Menten plot. Kinetic assays of Sfp PPTase $(1 \mu \mathrm{M})$ were carried out at $23^{\circ} \mathrm{C}$ at a constant concentration of compound $1(100 \mu \mathrm{M})$ by varying the concentration of HC-E388-ybbR ( $5 \mu \mathrm{M}-160 \mu \mathrm{M})$. Error bars indicate the standard deviation of quadruplet measurements. 

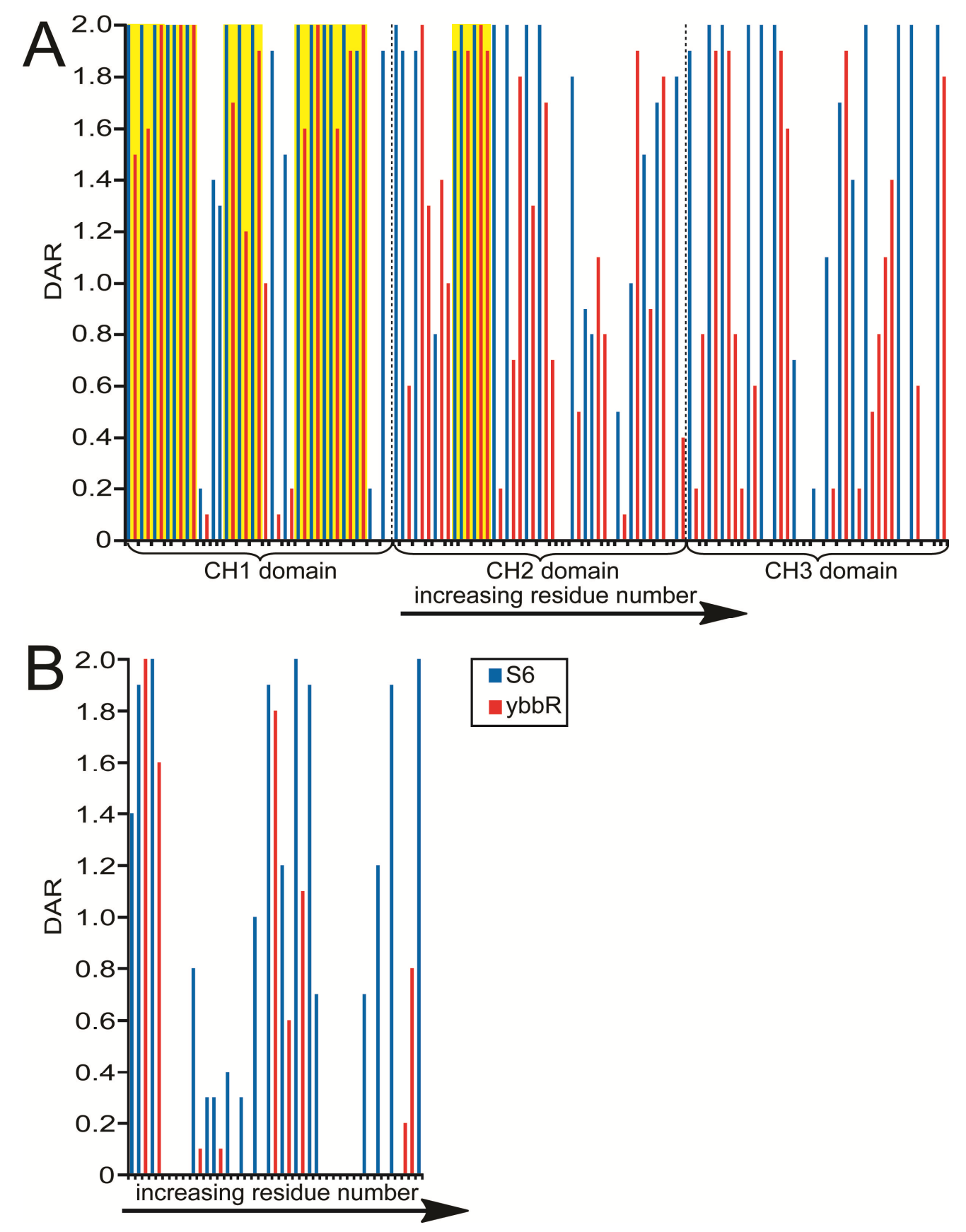

Fig. S6. Mapping of PPTase conjugation yields for numerous tag insertion sites. The degree of antibody labeling with compound $\mathbf{1}$ is expressed as drug-to-antibody ratio (DAR) and plotted against the peptide tag insertion site in heavy (A) and light (B) chains of the constant region of trastuzumab (IgG1 kappa). Surface-exposed loop regions with especially high conjugation yields (highlighted in yellow) primarily accumulate in the $\mathrm{CH} 1$ domain (residues $118-215$, Eu numbering). Peptide tags inserted in the $\mathrm{C}_{\mathrm{L}}$ domain of the kappa light chain generally have poor conjugation yields. DARs were determined by RPHPLC following incubation of $2.5 \mu \mathrm{M}$ antibody with $20 \mu \mathrm{M}$ compound 1 and $1 \mu \mathrm{M}$ Sfp PPTase for about $16 \mathrm{~h}$ at $20^{\circ} \mathrm{C}$ in $75 \mathrm{mM}$ Tris buffer (pH 8.0) supplemented with $12.5 \mathrm{mM} \mathrm{MgCl}_{2}$ and $20 \mathrm{mM} \mathrm{NaCl}$. 

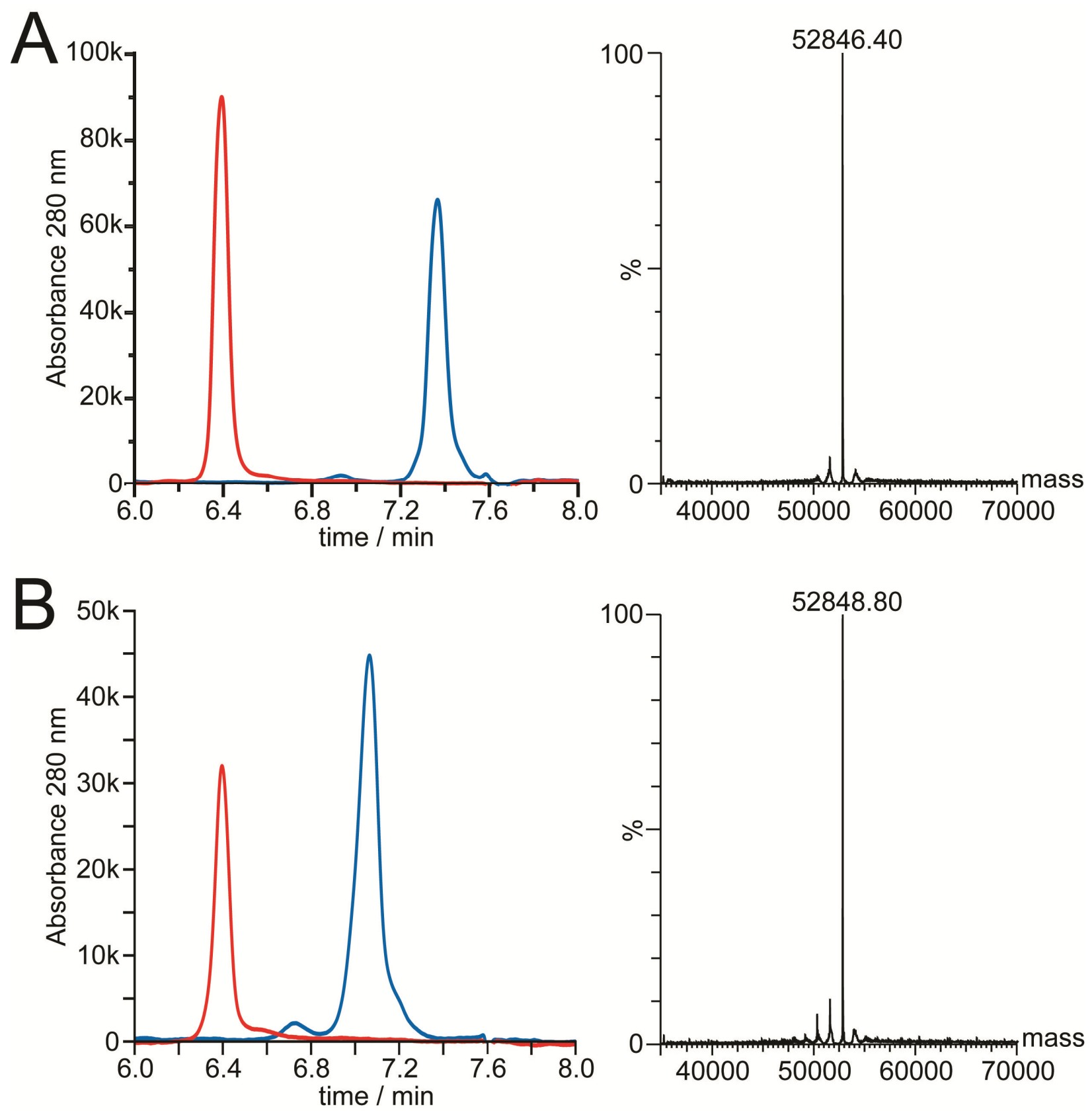

Fig. S7. PPTase-catalyzed drug conjugation is transferable to an antibody with different specificity, mAb1 IgG1. (A) On the left-hand side are shown reverse-phase HPLC traces of uncoupled mAb1 IgG1HC-E388-S6 (red trace) and the same antibody after conjugation with 1 (blue trace). On the right-hand side is shown a charge-state-deconvoluted ESI-MS spectrum confirming the formation of mAb1 IgG1-HCE388-S6-1. (B) On the left-hand side are shown reverse-phase HPLC traces of uncoupled mAb1 IgG1-HCT359-S6 (red trace) and the same antibody after conjugation with $\mathbf{1}$ (blue trace). On the right-hand side is shown a charge-state-deconvoluted ESI-MS spectrum confirming the formation of mAb1 IgG1-HCT359-S6-1. $2.5 \mu \mathrm{M}$ of mAb1 IgG1-HC-E388-S6 or mAb1 IgG1-HC-T359-S6 was conjugated with $40 \mu \mathrm{M}$ of 1 for approximately $16 \mathrm{~h}$ at $23^{\circ} \mathrm{C}$ in the presence of $1 \mu \mathrm{M} \mathrm{Sfp}$ enzyme in $75 \mathrm{mM}$ Tris buffer $(\mathrm{pH} 8.0)$ supplemented with $12.5 \mathrm{mM} \mathrm{MgCl}_{2}$. Calculated molecular weights of mAb1 IgG1-HC-E388-S6, mAb1 IgG1-HC-T359-S6, mAb1 IgG1-HC-E388-S6-1, and mAb1 IgG1-HC-T359-S6-1 are 51579.3 Da, 51579.3 Da, 
52844.8 Da, and 52844.8 Da, respectively. All expected masses of mAb1 IgG1 constructs assume pyroglutamate formation of the $\mathrm{N}$-terminal glutamine residue.

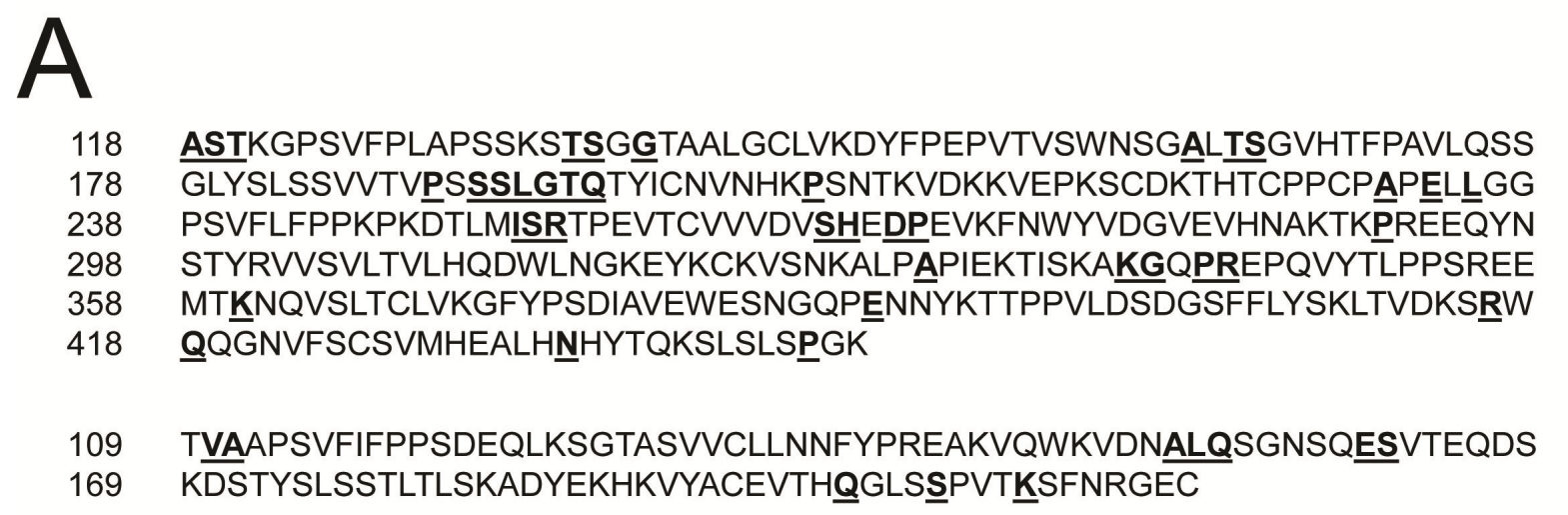

118 ASTKGPSVFPLAPSSKST $\underline{\mathbf{S} G \underline{G} T A A L G C L V K D Y F P E P V T V S W N S G A L T S G V H T F P A V L Q S S ~}$ GLYSLSSVVTVPSSSLGTQTYICNVNHKPSNTKVDKKVEPKSCDKTHTCPPCPAPELLGG PSVFLFPPKPKDTLMISRTPEVTCVVVDVSHEDPEVKFNWYVDGVEVHNAKTKPREEQYN 298 STYRVVSVLTVLHQDWLNGKEYKCKVSNKALPAPIEKTISKAKGQPREPQVYTLPPSREE 358 MTKNQVSLTCLVKGFYPSDIAVEWESNGQPENNYKTTPPVLDSDGSFFLYSKLTVDKSㅁW 418 QQGNVFSCSVMHEALHNHYTQKSLSLSPGKK

109 TVAAPSVFIFPPSDEQLKSGTASVVCLLNNFYPREAKVQWKVDNALQQSGNSQESVTEQDS 168 169 KDSTYSLSSTLTLSKADYEKHKVYACEVTHQGLSSPVTKSFNRGEC

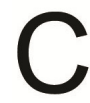

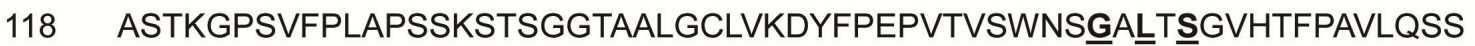
GLYSLSSVVTVPSSSLGTQTYICNVNHKPSNTKVDKKVEPKSCDKTHTCPPCPAPELLGG PSVFLFPPKPKDTLMISRTPEVTCVVVDVSHEDPEVKFNWYVDGVEVHNAKTKPREEQYN STYRVVSVLTVLHQDWLNGKEYKCKVSNKALPAPIEKTISKAKGQPREPQVYTLPPSREE MTKNQVSLTCLVKGFYPSDIAVEWESNGQPENNYKTTPPVLDSDGSFFLYSKLTVDKSRW

Fig. S8. Sequence locations of $\mathrm{S} 6 / \mathrm{ybbR} / \mathrm{A} 1$ tag insertion sites that display near quantitative conjugation with compound 1 . The amino acid sequences (one-letter symbols) correspond to the constant regions of heavy (top) and light (bottom) chains of trastuzumab. Each highlighted amino acid residue (bold and underlined) precedes an inserted S6 (A), ybbR (B), or A1 (C) peptide tag. Amino acid positions are numbered according to Edelman et al. ${ }^{7}$ 

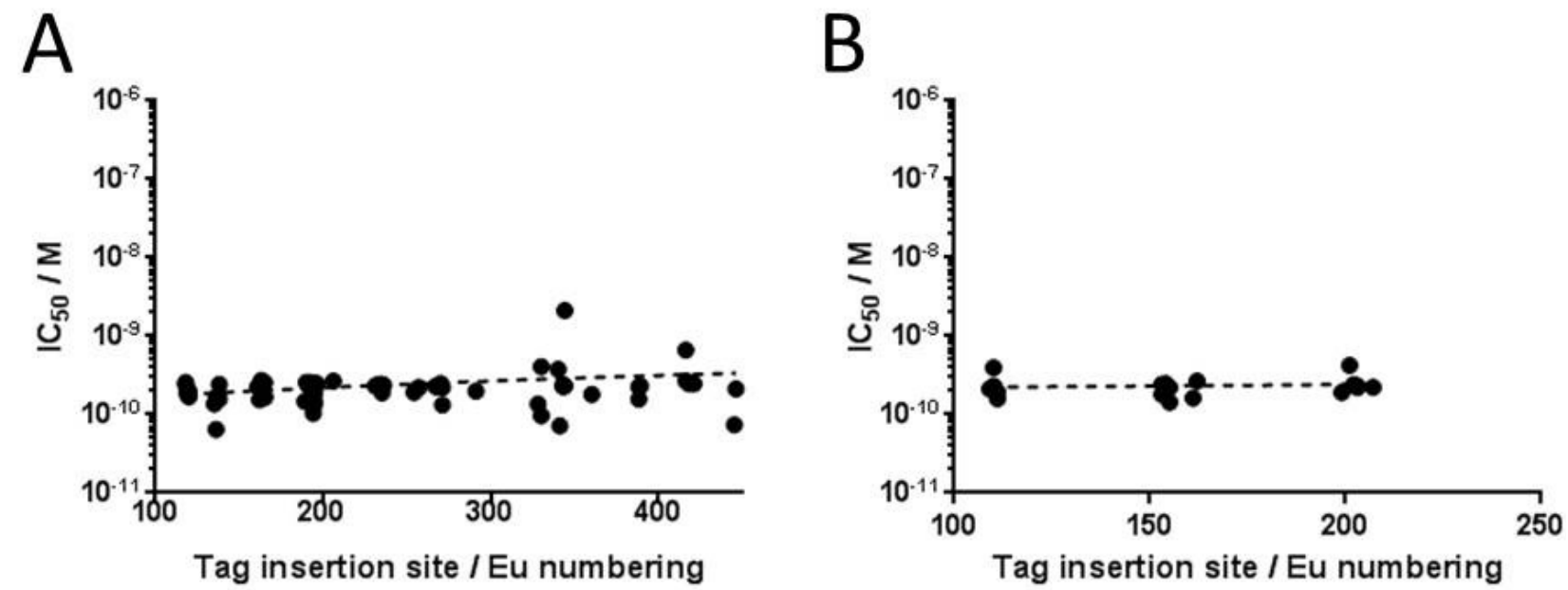

Fig. S9. The conjugation site has no impact on ADC in vitro cytotoxicity as exemplified for the HER2positive cell line HCC1954. (A) IC 50 values of 75 ADCs are plotted against S6/ybbR/A1 insertion sites of the heavy chain constant domains $(\mathrm{CH} 1, \mathrm{CH} 2, \mathrm{CH} 3)$ of trastuzumab. (B) IC 50 values of $19 \mathrm{ADCs}$ are plotted against $\mathrm{S} 6 / \mathrm{ybbR/A1}$ insertion sites of the $C_{L}$ domain of trastuzumab. Both plots were fitted using linear regression in Prism 6 (GraphPad Software, La Jolla, CA).

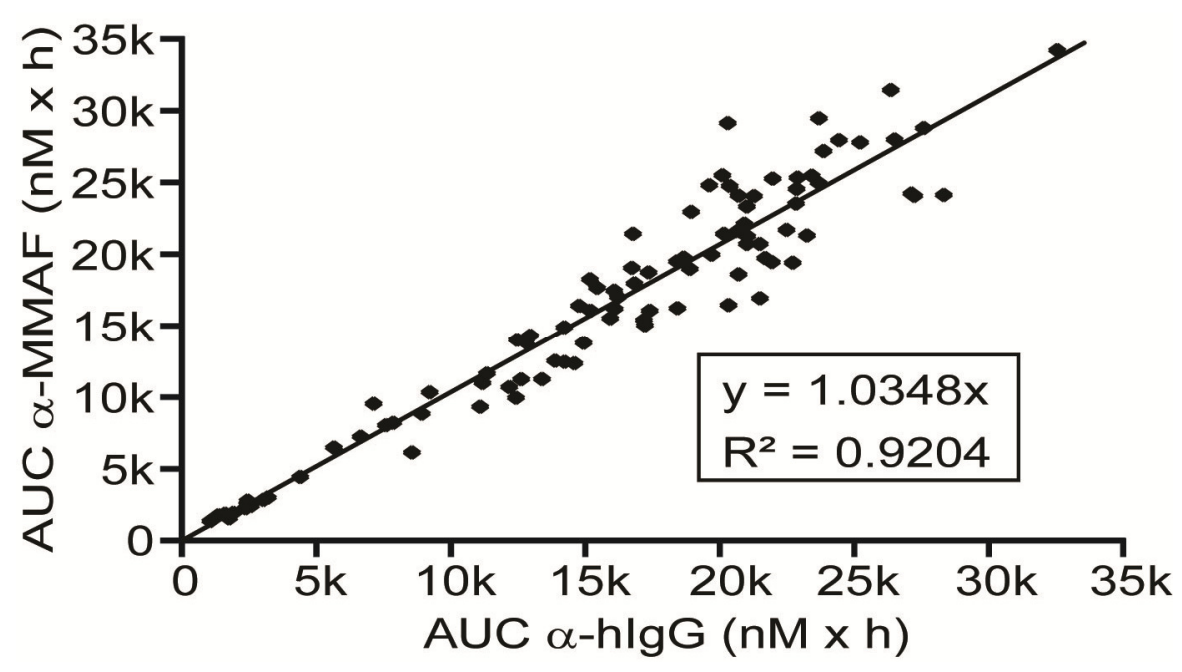

Fig. S10. The phosphopantetheine-based drug linkage is highly stable in circulation. Pharmacokinetic profiles of 95 peptide-tagged ADCs were assessed in non-tumor bearing mice over a time span of two weeks. Plasma levels of total IgG and antibody-bound drug were determined by ELISA using anti-hlgG and anti-auristatin antibodies, respectively. The plot illustrates the linear relationship between the AUC values of both titers. 


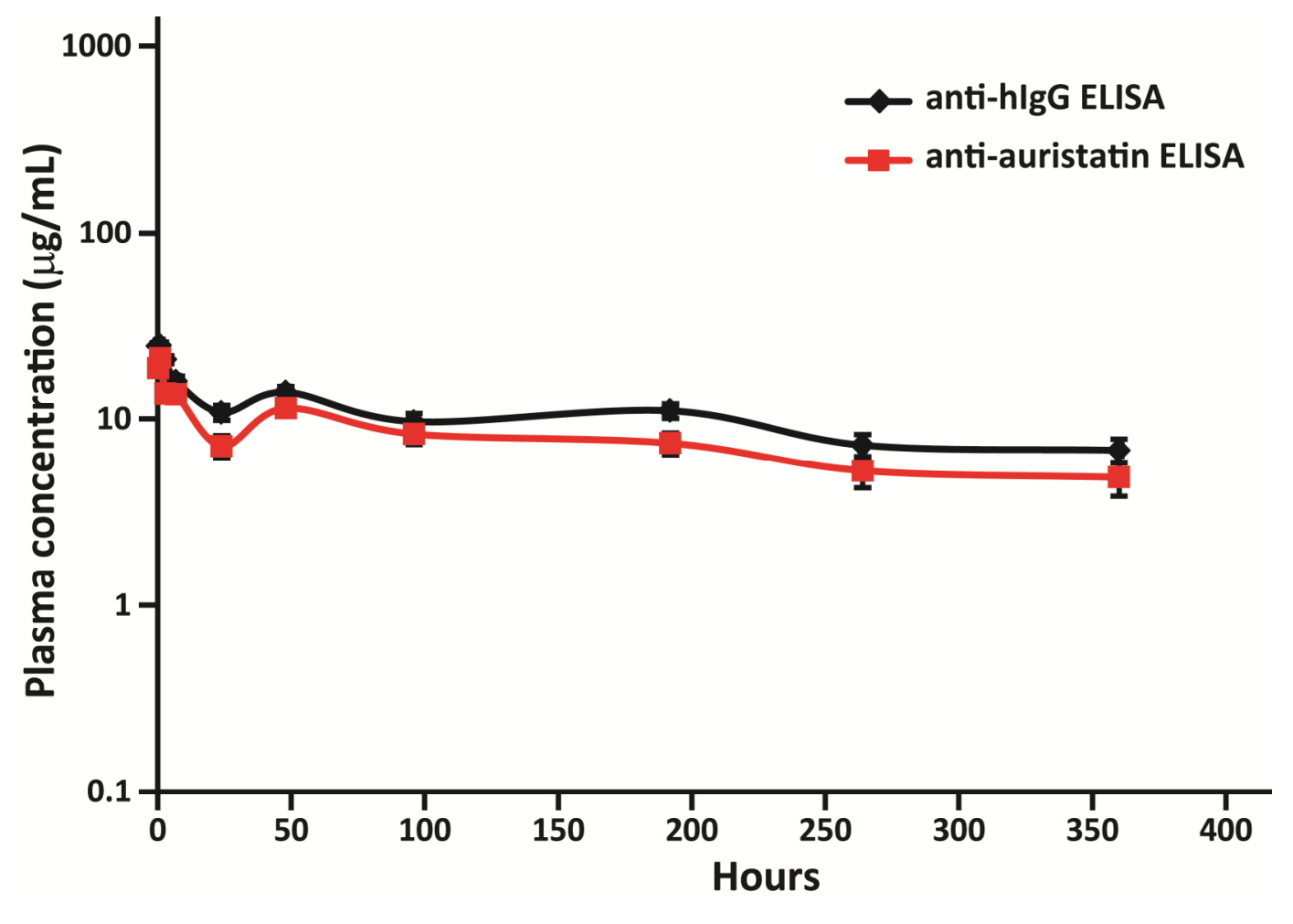

Fig. S11. Fifteen-day pharmacokinetic study of mAb2 IgG1-HC-E388-ybbR-2 in naïve mice by ELISA. $A D C$ and non-conjugated antibody were captured from plasma using immobilized antigen. Anti-hlgG and anti-auristatin antibodies were then used to determine titers of total antibody and intact ADC, respectively. 

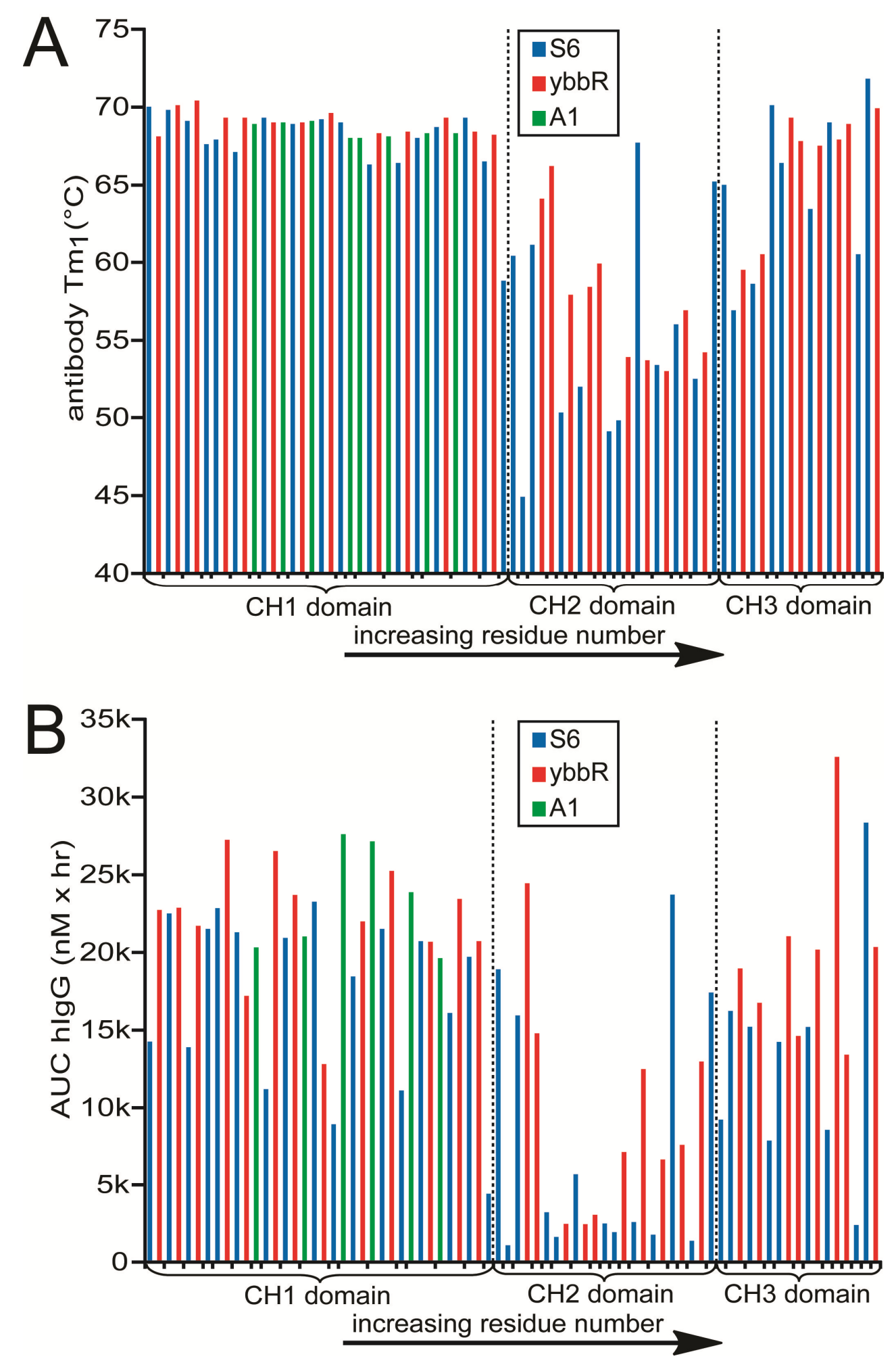

Fig. S12. The insertion site controls the thermal stability and pharmacokinetics of peptide-tagged antibodies/ADCs. (A) S6/ybbR/A1 insertion sites are plotted against the first melting transition, $\mathrm{Tm}_{1}$, of the corresponding peptide-tagged antibodies. (B) S6/ybbR/A1 insertion sites are plotted against the $A U C$ values of the total IgG ELISA of the respective PPTase-labeled ADCs. 


\section{Supplemental Tables}

Table S1. Characterization of 183 peptide-tagged anti-HER2 constructs derived from transient HEK293F expression using the Protein Expression and Purification Platform (PEPP).

\begin{tabular}{|c|c|c|c|c|c|}
\hline ADC name ${ }^{a}$ & $\begin{array}{c}\text { Antibody } \\
\text { yield } \\
\text { (mg/L) }\end{array}$ & DAR $^{c}$ & $\begin{array}{c}\text { Expected } \\
\text { mass antibody } \\
(\mathrm{Da})^{\mathrm{d}}\end{array}$ & $\begin{array}{c}\text { Expected } \\
\text { mass ADC } \\
(D a)^{e}\end{array}$ & $\begin{array}{c}\text { Observed } \\
\text { mass } \\
(\mathrm{Da})^{\dagger}\end{array}$ \\
\hline HC-A118-S6-1 & 10 & 2 & 50525 & 51790.5 & $\begin{array}{l}51792.7 \\
51814.6\end{array}$ \\
\hline HC-S119-S6-1 & 12 & 2 & 50525 & 51790.5 & 51792.4 \\
\hline HC-T120-S6-1 & 11 & 2 & 50525 & 51790.5 & 51797.2 \\
\hline HC-T135-S6-1 & 24 & 2 & 50525 & 51790.5 & 51792.8 \\
\hline HC-S136-S6-1 & 20 & 2 & 50525 & 51790.5 & 51792 \\
\hline HC-G138-S6-1 & 14 & 2 & 50525 & 51790.5 & $\begin{array}{l}51792.3 \\
51814.6\end{array}$ \\
\hline HC-E152-S6-1 & 3 & 0.2 & 50525 & 51790.5 & $\begin{array}{l}50528.4 \\
51794.8\end{array}$ \\
\hline HC-P153-S6-1 & 0 & $\mathrm{~N} / \mathrm{A}$ & 50525 & 51790.5 & $\mathrm{~N} / \mathrm{A}$ \\
\hline HC-N159-S6-1 & 0 & $\mathrm{~N} / \mathrm{A}$ & 50525 & 51790.5 & $N / A$ \\
\hline HC-S160-S6-1 & 10 & 1.4 & 50525 & 51790.5 & 51792 \\
\hline HC-G161-S6-1 & 9 & 1.3 & 50525 & 51790.5 & $\begin{array}{l}51798.0 \\
50529.2\end{array}$ \\
\hline HC-A162-S6-1 & 15 & 2 & 50525 & 51790.5 & 51798.4 \\
\hline HC-T164-S6-1 & 22 & 2 & 50525 & 51790.5 & 51796.8 \\
\hline HC-S165-S6-1 & 15 & 2 & 50525 & 51790.5 & 51794.4 \\
\hline HC-P171-S6-1 & 3 & $\mathrm{~N} / \mathrm{A}$ & 50525 & 51790.5 & $\mathrm{~N} / \mathrm{A}$ \\
\hline HC-S176-S6-1 & 8 & 1.9 & 50525 & 51790.5 & $\begin{array}{l}51791.7 \\
51812.9\end{array}$ \\
\hline HC-P189-S6-1 & 24 & 1.5 & 50525 & 51790.5 & 51792.4 \\
\hline HC-S191-S6-1 & 21 & 2 & 50525 & 51790.5 & $\begin{array}{l}51792.0 \\
51814.0\end{array}$ \\
\hline
\end{tabular}




\begin{tabular}{|c|c|c|c|c|c|}
\hline ADC name ${ }^{a}$ & $\begin{array}{c}\text { Antibody } \\
\text { yield } \\
\text { (mg/L) }\end{array}$ & DAR $^{c}$ & $\begin{array}{c}\text { Expected } \\
\text { mass antibody } \\
(\mathrm{Da})^{\mathrm{d}}\end{array}$ & $\begin{array}{c}\text { Expected } \\
\text { mass ADC } \\
(D a)^{e}\end{array}$ & $\begin{array}{c}\text { Observed } \\
\text { mass } \\
(\mathrm{Da})^{f}\end{array}$ \\
\hline HC-S192-S6-1 & 32 & 2 & 50525 & 51790.5 & $\begin{array}{l}51792.0 \\
51813.7\end{array}$ \\
\hline HC-L193-S6-1 & 18 & 2 & 50525 & 51790.5 & 51791 \\
\hline HC-G194-S6-1 & 19 & 2 & 50525 & 51790.5 & 51796.8 \\
\hline HC-T195-S6-1 & 17 & 2 & 50525 & 51790.5 & $\begin{array}{l}51800.0 \\
53918.8\end{array}$ \\
\hline HC-Q196-S6-1 & 23 & 1.9 & 50525 & 51790.5 & $\begin{array}{l}51791.9 \\
51813.5\end{array}$ \\
\hline HC-K205-S6-1 & 22 & 0.2 & 50525 & 51790.5 & $\begin{array}{l}50526.7 \\
51792.6 \\
50548.6\end{array}$ \\
\hline HC-P206-S6-1 & 25 & 1.9 & 50525 & 51790.5 & $\begin{array}{l}51792.1 \\
51813.9\end{array}$ \\
\hline HC-A231-S6-1 & 35 & 2 & 50525 & 51790.5 & $\begin{array}{l}51789.5 \\
51810.4\end{array}$ \\
\hline HC-E233-S6-1 & 13 & 1.9 & 50525 & 51790.5 & $\begin{array}{l}51789.5 \\
51770.4 \\
51809.6\end{array}$ \\
\hline HC-L235-S6-1 & 16 & 1.9 & 50525 & 51790.5 & $\begin{array}{l}51790.1 \\
51811.8\end{array}$ \\
\hline HC-P244-S6-1 & 12 & 0.8 & 50525 & 51790.5 & $\begin{array}{l}50522.7 \\
51790.6 \\
50545.4\end{array}$ \\
\hline HC-I253-S6-1 & 23 & 1.9 & 50525 & 51790.5 & $\begin{array}{l}51789.0 \\
51809.6\end{array}$ \\
\hline HC-S254-S6-1 & 20 & 2 & 50525 & 51790.5 & $\begin{array}{l}51789.5 \\
51810.5\end{array}$ \\
\hline HC-R255-S6-1 & 25 & 2 & 50525 & 51790.5 & $\begin{array}{l}51792.2 \\
51814.5\end{array}$ \\
\hline HC-S267-S6-1 & 20 & 2 & 50525 & 51790.5 & $\begin{array}{l}51789.2 \\
51810.1\end{array}$ \\
\hline HC-H268-S6-1 & 10 & 2 & 50525 & 51790.5 & $\begin{array}{l}51789.6 \\
51810.0\end{array}$ \\
\hline HC-E269-S6-1 & 0 & $\mathrm{~N} / \mathrm{A}$ & 50525 & 51790.5 & $\mathrm{~N} / \mathrm{A}$ \\
\hline HC-D270-S6-1 & 18 & 2 & 50525 & 51790.5 & $\begin{array}{l}51789.8 \\
51771.0 \\
51811.2\end{array}$ \\
\hline
\end{tabular}




\begin{tabular}{|c|c|c|c|c|c|}
\hline ADC name ${ }^{a}$ & $\begin{array}{c}\text { Antibody } \\
\text { yield } \\
\text { (mg/L) }\end{array}$ & DAR $^{c}$ & $\begin{array}{c}\text { Expected } \\
\text { mass antibody } \\
(D a)^{d}\end{array}$ & $\begin{array}{c}\text { Expected } \\
\text { mass ADC } \\
(D a)^{e}\end{array}$ & $\begin{array}{c}\text { Observed } \\
\text { mass } \\
(\mathrm{Da})^{f}\end{array}$ \\
\hline HC-P271-S6-1 & 8 & 2 & 50525 & 51790.5 & 51796.4 \\
\hline HC-P291-S6-1 & 23 & 1.8 & 50525 & 51790.5 & $\begin{array}{l}51789.8 \\
51811.3\end{array}$ \\
\hline HC-T307-S6-1 & 4 & n.d. & 50525 & 51790.5 & $\begin{array}{l}51793.6 \\
50526.4\end{array}$ \\
\hline HC-L309-S6-1 & 10 & n.d. & 50525 & 51790.5 & $\begin{array}{l}51795.6 \\
50530.8\end{array}$ \\
\hline HC-N315-S6-1 & 13 & 0.9 & 50525 & 51790.5 & $\begin{array}{l}51788.9 \\
50523.3 \\
51810.4\end{array}$ \\
\hline HC-G316-S6-1 & 7 & 0.8 & 50525 & 51790.5 & $\begin{array}{l}50524.1 \\
51789.7 \\
50545.9\end{array}$ \\
\hline HC-A327-S6-1 & 14 & 0.5 & 50525 & 51790.5 & $\begin{array}{l}51789.9 \\
50522.7\end{array}$ \\
\hline HC-L328-S6-1 & 16 & 1 & 50525 & 51790.5 & $\begin{array}{l}51789.8 \\
50523.2 \\
51810.9\end{array}$ \\
\hline HC-P329-S6-1 & 18 & 1.5 & 50525 & 51790.5 & $\begin{array}{l}51790.1 \\
51811.9\end{array}$ \\
\hline HC-A330-S6-1 & 9 & 1.7 & 50525 & 51790.5 & $\begin{array}{l}51792.4 \\
50527.6\end{array}$ \\
\hline HC-K340-S6-1 & 6 & 1.8 & 50525 & 51790.5 & $\begin{array}{l}51792.4 \\
51604.8\end{array}$ \\
\hline HC-G341-S6-1 & 26 & 1.9 & 50525 & 51790.5 & 51790 \\
\hline HC-Q342-S6-1 & 0 & $N / A$ & 50525 & 51790.5 & $\mathrm{~N} / \mathrm{A}$ \\
\hline HC-P343-S6-1 & 14 & 2 & 50525 & 51790.5 & $\begin{array}{l}51792.2 \\
51809.3\end{array}$ \\
\hline HC-R344-S6-1 & 16 & 2 & 50525 & 51790.5 & 51794.4 \\
\hline HC-K360-S6-1 & 26 & 2 & 50525 & 51790.5 & 51796.8 \\
\hline HC-N384-S6-1 & 2 & 2 & 50525 & 51790.5 & 51792.8 \\
\hline HC-E388-S6-1 & 23 & 2 & 50525 & 51790.5 & 51794.4 \\
\hline HC-T394-S6-1 & 3 & 0.7 & 50525 & 51790.5 & $\begin{array}{l}51793.2 \\
50525.2\end{array}$ \\
\hline
\end{tabular}




\begin{tabular}{|c|c|c|c|c|c|}
\hline$A D C$ name $^{a}$ & $\begin{array}{c}\text { Antibody } \\
\text { yield } \\
\text { (mg/L) }\end{array}$ & DAR $^{c}$ & $\begin{array}{c}\text { Expected } \\
\text { mass antibody } \\
(\mathrm{Da})^{\mathrm{d}}\end{array}$ & $\begin{array}{c}\text { Expected } \\
\text { mass ADC } \\
(D a)^{e}\end{array}$ & $\begin{array}{c}\text { Observed } \\
\text { mass } \\
(\mathrm{Da})^{f}\end{array}$ \\
\hline HC-P395-S6-1 & 4 & n.d. & 50525 & 51790.5 & $\begin{array}{l}51794.6 \\
51773.9 \\
51820.4 \\
\end{array}$ \\
\hline HC-D401-S6-1 & 10 & 0.2 & 50525 & 51790.5 & $\begin{array}{l}51793.7 \\
51818.2\end{array}$ \\
\hline HC-S415-S6-1 & 5 & 1.1 & 50525 & 51790.5 & $\begin{array}{l}51792.8 \\
50526.8\end{array}$ \\
\hline HC-R416-S6-1 & 5 & 1.7 & 50525 & 51790.5 & 51794.1 \\
\hline HC-W417-S6-1 & 15 & 1.4 & 50525 & 51790.5 & $\begin{array}{c}51798.8 \\
51921.6^{9}\end{array}$ \\
\hline HC-Q418-S6-1 & 9 & 2 & 50525 & 51790.5 & 51794.4 \\
\hline $\mathrm{HC}-\mathrm{H} 433-\mathrm{S} 6-1$ & 5 & 2 & 50525 & 51790.5 & $\begin{array}{c}51793.6 \\
51922.4^{g} \\
51735.6\end{array}$ \\
\hline HC-N434-S6-1 & 20 & 2 & 50525 & 51790.5 & $\begin{array}{c}51797.6 \\
51923.6^{g}\end{array}$ \\
\hline HC-L443-S6-1 & 24 & 0 & 50525 & 51790.5 & $\begin{array}{l}50527.2 \\
50547.1\end{array}$ \\
\hline HC-P445-S6-1 & 10 & 2 & 50525 & 51790.5 & $\begin{array}{c}51786.8 \\
51915.6^{g} \\
51729.6\end{array}$ \\
\hline HC-A118-ybbR-1 & 18 & 1.5 & 50331.8 & 51597.3 & $\begin{array}{l}51598.4 \\
51618.3\end{array}$ \\
\hline HC-S119-ybbR-1 & 15 & 1.6 & 50331.8 & 51597.3 & 51602.4 \\
\hline HC-T120-ybbR-1 & 27 & 2 & 50331.8 & 51597.3 & 51600.8 \\
\hline HC-S136-ybbR-1 & 19 & 2 & 50331.8 & 51597.3 & 51603.2 \\
\hline HC-G138-ybbR-1 & 21 & 2 & 50331.8 & 51597.3 & 51601.6 \\
\hline HC-P153-ybbR-1 & 15 & 0.1 & 50331.8 & 51597.3 & 50339.6 \\
\hline HC-N159-ybbR-1 & 13 & n.d. & 50331.8 & 51597.3 & $\begin{array}{l}50334.4 \\
51600.4\end{array}$ \\
\hline HC-A162-ybbR-1 & 16 & 1.7 & 50331.8 & 51597.3 & $\begin{array}{l}51598.3 \\
51618.5\end{array}$ \\
\hline HC-T164-ybbR-1 & 18 & 1.2 & 50331.8 & 51597.3 & $\begin{array}{l}51597.7 \\
51616.8\end{array}$ \\
\hline
\end{tabular}




\begin{tabular}{|c|c|c|c|c|c|}
\hline ADC name ${ }^{a}$ & $\begin{array}{c}\text { Antibody } \\
\text { yield } \\
\text { (mg/L) }\end{array}$ & DAR $^{c}$ & $\begin{array}{c}\text { Expected } \\
\text { mass antibody } \\
(\mathrm{Da})^{\mathrm{d}}\end{array}$ & $\begin{array}{c}\text { Expected } \\
\text { mass ADC } \\
(D a)^{e}\end{array}$ & $\begin{array}{c}\text { Observed } \\
\text { mass } \\
(\mathrm{Da})^{f}\end{array}$ \\
\hline HC-S165-ybbR-1 & 23 & 1.9 & 50331.8 & 51597.3 & 51595.2 \\
\hline HC-P171-ybbR-1 & 15 & 1 & 50331.8 & 51597.3 & $\begin{array}{l}50332.9 \\
50353.8\end{array}$ \\
\hline HC-S176-ybbR-1 & 13 & 0.1 & 50331.8 & 51597.3 & $\begin{array}{l}50333.0 \\
50354.0\end{array}$ \\
\hline HC-S190-ybbR-1 & 23 & 0.2 & 50331.8 & 51597.3 & $\begin{array}{l}50333.6 \\
51600.8\end{array}$ \\
\hline HC-S191-ybbR-1 & 24 & 1.6 & 50331.8 & 51597.3 & $\begin{array}{l}51598.9 \\
51620.3\end{array}$ \\
\hline HC-S192-ybbR-1 & 21 & 2 & 50331.8 & 51597.3 & $\begin{array}{l}51598.4 \\
51618.8\end{array}$ \\
\hline HC-G194-ybbR-1 & 14 & 1.6 & 50331.8 & 51597.3 & 51599.2 \\
\hline HC-T195-ybbR-1 & 14 & 1.9 & 50331.8 & 51597.3 & $\begin{array}{l}51599.0 \\
51617.2\end{array}$ \\
\hline HC-Q196-ybbR-1 & 21 & 2 & 50331.8 & 51597.3 & $\begin{array}{l}51598.1 \\
51618.7\end{array}$ \\
\hline HC-K205-ybbR-1 & 24 & 0 & 50331.8 & 51597.3 & 50327.6 \\
\hline HC-P206-ybbR-1 & 23 & 0 & 50331.8 & 51597.3 & $\begin{array}{l}50333.3 \\
50354.7\end{array}$ \\
\hline HC-E233-ybbR-1 & 28 & 0.6 & 50331.8 & 51597.3 & $\begin{array}{l}50330.8 \\
51596.6 \\
51615.6\end{array}$ \\
\hline HC-L235-ybbR-1 & 24 & 2 & 50331.8 & 51597.3 & $\begin{array}{l}51596.7 \\
51617.5\end{array}$ \\
\hline HC-G236-ybbR-1 & 22 & 1.3 & 50331.8 & 51597.3 & $\begin{array}{l}51598.8 \\
51620.7\end{array}$ \\
\hline HC-P244-ybbR-1 & 8 & 1.4 & 50331.8 & 51597.3 & $\begin{array}{l}51596.8 \\
51614.6\end{array}$ \\
\hline HC-P245-ybbR-1 & 22 & 1 & 50331.8 & 51597.3 & $\begin{array}{l}50330.6 \\
51595.9 \\
50351.5\end{array}$ \\
\hline HC-1253-ybbR-1 & 0 & $\mathrm{~N} / \mathrm{A}$ & 50331.8 & 51597.3 & $N / A$ \\
\hline HC-S254-ybbR-1 & 24 & 1.9 & 50331.8 & 51597.3 & $\begin{array}{l}51596.6 \\
51616.8\end{array}$ \\
\hline HC-R255-ybbR-1 & 21 & 2 & 50331.8 & 51597.3 & $\begin{array}{l}51596.3 \\
51616.5\end{array}$ \\
\hline
\end{tabular}




\begin{tabular}{|c|c|c|c|c|c|}
\hline$A D C$ name $^{a}$ & $\begin{array}{c}\text { Antibody } \\
\text { yield } \\
\text { (mg/L) }\end{array}$ & DAR $^{c}$ & $\begin{array}{c}\text { Expected } \\
\text { mass antibody } \\
(\mathrm{Da})^{\mathrm{d}}\end{array}$ & $\begin{array}{c}\text { Expected } \\
\text { mass ADC } \\
(D a)^{e}\end{array}$ & $\begin{array}{c}\text { Observed } \\
\text { mass } \\
(\mathrm{Da})^{f}\end{array}$ \\
\hline HC-P257-ybbR-1 & 22 & 1.9 & 50331.8 & 51597.3 & $\begin{array}{l}51596.3 \\
51616.1\end{array}$ \\
\hline HC-S267-ybbR-1 & 23 & 0.2 & 50331.8 & 51597.3 & $\begin{array}{l}51596.0 \\
50330.9 \\
51615.6\end{array}$ \\
\hline HC-H268-ybbR-1 & 22 & 0.7 & 50331.8 & 51597.3 & $\begin{array}{l}51596.2 \\
50331.0 \\
51616.8\end{array}$ \\
\hline HC-E269-ybbR-1 & 17 & 1.8 & 50331.8 & 51597.3 & $\begin{array}{l}51598.7 \\
51620.0\end{array}$ \\
\hline HC-D270-ybbR-1 & 26 & 1.3 & 50331.8 & 51597.3 & $\begin{array}{l}51596.4 \\
51616.5\end{array}$ \\
\hline HC-P271-ybbR-1 & 22 & 1.7 & 50331.8 & 51597.3 & $\begin{array}{l}51595.9 \\
51615.4\end{array}$ \\
\hline HC-D280-ybbR-1 & 4 & 0.7 & 50331.8 & 51597.3 & $\begin{array}{l}50330.8 \\
51596.3 \\
50351.7\end{array}$ \\
\hline HC-H285-ybbR-1 & 25 & 0 & 50331.8 & 51597.3 & $\begin{array}{l}50331.0 \\
50352.7\end{array}$ \\
\hline HC-N286-ybbR-1 & 20 & 0 & 50331.8 & 51597.3 & $\begin{array}{l}50332.0 \\
50354.1\end{array}$ \\
\hline HC-P291-ybbR-1 & 21 & 0.5 & 50331.8 & 51597.3 & $\begin{array}{l}50333.5 \\
51598.8 \\
51620.0\end{array}$ \\
\hline HC-N315-ybbR-1 & 15 & n.d. & 50331.8 & 51597.3 & $\begin{array}{l}50331.5 \\
51596.8 \\
50353.1\end{array}$ \\
\hline HC-G316-ybbR-1 & 9 & 1.1 & 50331.8 & 51597.3 & $\begin{array}{l}51596.6 \\
50331.0 \\
51614.0\end{array}$ \\
\hline HC-K317-ybbR-1 & 10 & 0.8 & 50331.8 & 51597.3 & $\begin{array}{l}50330.9 \\
51596.3 \\
50352.1\end{array}$ \\
\hline HC-K326-ybbR-1 & 15 & 0 & 50331.8 & 51597.3 & $\begin{array}{l}50330.8 \\
51597.2\end{array}$ \\
\hline HC-A327-ybbR-1 & 25 & 0.1 & 50331.8 & 51597.3 & $\begin{array}{l}50333.6 \\
50355.1\end{array}$ \\
\hline HC-L328-ybbR-1 & 13 & 1.9 & 50331.8 & 51597.3 & 51598.8 \\
\hline HC-P329-ybbR-1 & 7 & 0.9 & 50331.8 & 51597.3 & $\begin{array}{l}51601.6 \\
50334.8\end{array}$ \\
\hline HC-A330-ybbR-1 & 25 & 1.8 & 50331.8 & 51597.3 & 51602.4 \\
\hline
\end{tabular}




\begin{tabular}{|c|c|c|c|c|c|}
\hline ADC name ${ }^{a}$ & $\begin{array}{l}\text { Antibody } \\
\text { yield } \\
\text { (mg/L) }\end{array}$ & $D_{A}{ }^{c}$ & $\begin{array}{c}\text { Expected } \\
\text { mass antibody } \\
(D a)^{d}\end{array}$ & $\begin{array}{c}\text { Expected } \\
\text { mass ADC } \\
(D a)^{e}\end{array}$ & $\begin{array}{l}\text { Observed } \\
\text { mass } \\
(\mathrm{Da})^{f}\end{array}$ \\
\hline HC-A339-ybbR-1 & 25 & 0 & 50331.8 & 51597.3 & 50333.6 \\
\hline HC-K340-ybbR-1 & 27 & 0.4 & 50331.8 & 51597.3 & $\begin{array}{l}51600.4 \\
50333.2\end{array}$ \\
\hline HC-G341-ybbR-1 & 25 & 0.2 & 50331.8 & 51597.3 & $\begin{array}{l}51599.9 \\
50334.7\end{array}$ \\
\hline HC-Q342-ybbR-1 & 28 & 0.8 & 50331.8 & 51597.3 & $\begin{array}{l}51599.8 \\
50334.5\end{array}$ \\
\hline HC-P343-ybbR-1 & 24 & 1.9 & 50331.8 & 51597.3 & $\begin{array}{l}51599.1 \\
51615.8\end{array}$ \\
\hline HC-R344-ybbR-1 & 29 & 1.9 & 50331.8 & 51597.3 & $\begin{array}{l}51600.1 \\
51616.6\end{array}$ \\
\hline HC-E356-ybbR-1 & 20 & 0.8 & 50331.8 & 51597.3 & $\begin{array}{l}51600.8 \\
50335.1 \\
51616.8\end{array}$ \\
\hline HC-M358-ybbR-1 & 26 & 0.2 & 50331.8 & 51597.3 & $\begin{array}{l}50333.9 \\
51599.4\end{array}$ \\
\hline HC-K360-ybbR-1 & 24 & 0.6 & 50331.8 & 51597.3 & $\begin{array}{l}51599.9 \\
51615.1\end{array}$ \\
\hline HC-N384-ybbR-1 & 24 & 0 & 50331.8 & 51597.3 & $\begin{array}{l}50334.3 \\
50354.2\end{array}$ \\
\hline HC-E388-ybbR-1 & 21 & 1.9 & 50331.8 & 51597.3 & 51601.2 \\
\hline HC-N389-ybbR-1 & 25 & 1.6 & 50331.8 & 51597.3 & $\begin{array}{l}51600.1 \\
51620.9\end{array}$ \\
\hline HC-P395-ybbR-1 & 25 & 0 & 50331.8 & 51597.3 & $\begin{array}{l}50334.4 \\
50352.8\end{array}$ \\
\hline HC-D399-ybbR-1 & 11 & 0 & 50331.8 & 51597.3 & $\begin{array}{l}50335.1 \\
50353.6\end{array}$ \\
\hline HC-D401-ybbR-1 & 23 & 0 & 50331.8 & 51597.3 & $\begin{array}{l}50334.9 \\
50353.0\end{array}$ \\
\hline HC-S415-ybbR-1 & 21 & 0.2 & 50331.8 & 51597.3 & $\begin{array}{l}50335.0 \\
51600.5\end{array}$ \\
\hline HC-R416-ybbR-1 & 15 & 1.9 & 50331.8 & 51597.3 & $\begin{array}{l}51599.9 \\
51615.8\end{array}$ \\
\hline HC-W417-ybbR-1 & 9 & 0.2 & 50331.8 & 51597.3 & $\begin{array}{l}50334.8 \\
51599.9 \\
50353.4\end{array}$ \\
\hline HC-Q418-ybbR-1 & 22 & 0.5 & 50331.8 & 51597.3 & $\begin{array}{l}51600.5 \\
50335.2 \\
51616.7\end{array}$ \\
\hline
\end{tabular}




\begin{tabular}{|c|c|c|c|c|c|}
\hline$A D C$ name ${ }^{a}$ & $\begin{array}{c}\text { Antibody } \\
\text { yield } \\
\text { (mg/L) }\end{array}$ & $D_{A}{ }^{c}$ & $\begin{array}{c}\text { Expected } \\
\text { mass antibody } \\
(D a)^{d}\end{array}$ & $\begin{array}{c}\text { Expected } \\
\text { mass ADC } \\
(D a)^{e}\end{array}$ & $\begin{array}{c}\text { Observed } \\
\text { mass } \\
(\mathrm{Da})^{f}\end{array}$ \\
\hline HC-Q419-ybbR-1 & 21 & 0.8 & 50331.8 & 51597.3 & $\begin{array}{l}51600.0 \\
51616.5\end{array}$ \\
\hline HC-G420-ybbR-1 & 22 & 1.1 & 50331.8 & 51597.3 & $\begin{array}{l}51599.5 \\
51616.0\end{array}$ \\
\hline HC-N421-ybbR-1 & 24 & 1.4 & 50331.8 & 51597.3 & $\begin{array}{l}51600.6 \\
51614.9\end{array}$ \\
\hline HC-H433-ybbR-1 & 26 & 0 & 50331.8 & 51597.3 & $\begin{array}{l}50334.7 \\
50276.2\end{array}$ \\
\hline HC-N434-ybbR-1 & 25 & 0.6 & 50331.8 & 51597.3 & $\begin{array}{l}51592.4 \\
50326.8 \\
50268.8\end{array}$ \\
\hline HC-L443-ybbR-1 & 26 & 0 & 50331.8 & 51597.3 & $\begin{array}{l}50334.5 \\
50275.8 \\
50353.4\end{array}$ \\
\hline HC-G446-ybbR-1 & 29 & 1.8 & 50331.8 & 51597.3 & 51595.2 \\
\hline LC-T109-S6-1 & 34 & 1.4 & 24811.6 & 26077.1 & $\begin{array}{l}26077.8 \\
26058.3 \\
26096.4\end{array}$ \\
\hline LC-V110-S6-1 & 5 & 1.9 & 24811.6 & 26077.1 & 26076.4 \\
\hline LC-A111-S6-1 & 13 & 2 & 24811.6 & 26077.1 & 26075.6 \\
\hline LC-P119-S6-1 & 1 & $\mathrm{~N} / \mathrm{A}$ & 24811.6 & 26077.1 & $\mathrm{~N} / \mathrm{A}$ \\
\hline LC-D122-S6-1 & 1 & $\mathrm{~N} / \mathrm{A}$ & 24811.6 & 26077.1 & $N / A$ \\
\hline LC-Y140-S6-1 & 3 & 0.8 & 24811.6 & 26077.1 & 26077.2 \\
\hline LC-P141-S6-1 & 3 & 0.3 & 24811.6 & 26077.1 & 26076.8 \\
\hline LC-R142-S6-1 & 5 & 0.3 & 24811.6 & 26077.1 & $\begin{array}{l}26077.7 \\
24811.8 \\
26097.2\end{array}$ \\
\hline LC-E143-S6-1 & 6 & 0.4 & 24811.6 & 26077.1 & $\begin{array}{l}26075.6 \\
26097.6\end{array}$ \\
\hline LC-D151-S6-1 & 16 & 0.3 & 24811.6 & 26077.1 & $\begin{array}{l}24811.7 \\
26077.3 \\
24829.7\end{array}$ \\
\hline LC-N152-S6-1 & 5 & 1 & 24811.6 & 26077.1 & 26077.2 \\
\hline
\end{tabular}




\begin{tabular}{|c|c|c|c|c|c|}
\hline ADC name ${ }^{a}$ & $\begin{array}{l}\text { Antibody } \\
\text { yield } \\
(\mathrm{mg} / \mathrm{L})^{b}\end{array}$ & $\operatorname{DAR}^{\mathrm{c}}$ & $\begin{array}{c}\text { Expected } \\
\text { mass antibody } \\
(\mathrm{Da})^{\mathrm{d}}\end{array}$ & $\begin{array}{c}\text { Expected } \\
\text { mass ADC } \\
(D a)^{e}\end{array}$ & $\begin{array}{l}\text { Observed } \\
\text { mass } \\
(\mathrm{Da})^{f}\end{array}$ \\
\hline LC-A153-S6-1 & 13 & 1.9 & 24811.6 & 26077.1 & $\begin{array}{l}26077.7 \\
26096.6\end{array}$ \\
\hline LC-L154-S6-1 & 21 & 1.2 & 24811.6 & 26077.1 & $\begin{array}{l}26078.2 \\
26096.9\end{array}$ \\
\hline LC-Q155-S6-1 & 14 & 2 & 24811.6 & 26077.1 & 26075.2 \\
\hline LC-E161-S6-1 & 19 & 1.9 & 24811.6 & 26077.1 & $\begin{array}{l}26077.6 \\
26097.6\end{array}$ \\
\hline LC-S162-S6-1 & 17 & 0.7 & 24811.6 & 26077.1 & 26077.2 \\
\hline LC-T164-S6-1 & 14 & 0 & 24811.6 & 26077.1 & 24810 \\
\hline LC-E165-S6-1 & 0 & $\mathrm{~N} / \mathrm{A}$ & 24811.6 & 26077.1 & $\mathrm{~N} / \mathrm{A}$ \\
\hline LC-Q166-S6-1 & 17 & 0 & 24811.6 & 26077.1 & $\begin{array}{l}24810.4 \\
24832.4\end{array}$ \\
\hline LC-D167-S6-1 & 24 & 0.7 & 24811.6 & 26077.1 & $\begin{array}{l}26077.4 \\
24812.3 \\
26096.5\end{array}$ \\
\hline LC-T197-S6-1 & 8 & 1.2 & 24811.6 & 26077.1 & $\begin{array}{l}24812.0 \\
26077.9 \\
24831.4\end{array}$ \\
\hline LC-Q199-S6-1 & 5 & 1.9 & 24811.6 & 26077.1 & 26076 \\
\hline LC-S202-S6-1 & 8 & 2 & 24811.6 & 26077.1 & $\begin{array}{l}26077.4 \\
26095.9\end{array}$ \\
\hline LC-V110-ybbR-1 & 15 & 2 & 24618.4 & 25883.9 & 25883.2 \\
\hline LC-A111-ybbR-1 & 17 & 1.6 & 24618.4 & 25883.9 & 25881.2 \\
\hline LC-P119-ybbR-1 & 13 & 0 & 24618.4 & 25883.9 & $\begin{array}{l}24618.1 \\
24637.6\end{array}$ \\
\hline LC-P120-ybbR-1 & 9 & 0 & 24618.4 & 25883.9 & 24617.2 \\
\hline LC-S121-ybbR-1 & 4 & 0 & 24618.4 & 25883.9 & 24616.8 \\
\hline LC-D122-ybbR-1 & 2 & 0 & 24618.4 & 25883.9 & 24616.8 \\
\hline LC-Y140-ybbR-1 & 5 & 0.1 & 24618.4 & 25883.9 & 24616.4 \\
\hline
\end{tabular}




\begin{tabular}{|c|c|c|c|c|c|}
\hline ADC name ${ }^{a}$ & $\begin{array}{c}\text { Antibody } \\
\text { yield } \\
\text { (mg/L) }\end{array}$ & $D_{A}{ }^{c}$ & $\begin{array}{c}\text { Expected } \\
\text { mass antibody } \\
(\mathrm{Da})^{\mathrm{d}}\end{array}$ & $\begin{array}{c}\text { Expected } \\
\text { mass ADC } \\
(\mathrm{Da})^{\mathrm{e}}\end{array}$ & $\begin{array}{l}\text { Observed } \\
\text { mass } \\
(\mathrm{Da})^{\dagger}\end{array}$ \\
\hline LC-R142-ybbR-1 & 13 & 0.1 & 24618.4 & 25883.9 & $\begin{array}{l}24618.8 \\
25884.0 \\
24639.3\end{array}$ \\
\hline LC-E143-ybbR-1 & 10 & 0 & 24618.4 & 25883.9 & 24616.8 \\
\hline LC-D151-ybbR-1 & 17 & 0 & 24618.4 & 25883.9 & 24617.2 \\
\hline LC-N152-ybbR-1 & 17 & 0 & 24618.4 & 25883.9 & 24616.8 \\
\hline LC-A153-ybbR-1 & 20 & 1.8 & 24618.4 & 25883.9 & 25882.8 \\
\hline LC-L154-ybbR-1 & 25 & 0.6 & 24618.4 & 25883.9 & $\begin{array}{l}25884.6 \\
24618.9 \\
25904.2\end{array}$ \\
\hline LC-Q155-ybbR-1 & 27 & 1.1 & 24618.4 & 25883.9 & $\begin{array}{l}25883.9 \\
24619.0 \\
25903.2\end{array}$ \\
\hline LC-S162-ybbR-1 & 7 & 0 & 24618.4 & 25883.9 & 24616.4 \\
\hline LC-T164-ybbR-1 & 10 & 0 & 24618.4 & 25883.9 & 24616.4 \\
\hline LC-E165-ybbR-1 & 29 & 0 & 24618.4 & 25883.9 & $\begin{array}{l}24618.9 \\
24639.4\end{array}$ \\
\hline LC-Q166-ybbR-1 & 20 & 0 & 24618.4 & 25883.9 & 24617.2 \\
\hline LC-D167-ybbR-1 & 28 & 0 & 24618.4 & 25883.9 & $\begin{array}{l}24618.8 \\
24639.0\end{array}$ \\
\hline LC-T197-ybbR-1 & 5 & 0 & 24618.4 & 25883.9 & 24615.2 \\
\hline LC-Q199-ybbR-1 & 7 & 0 & 24618.4 & 25883.9 & 24617.2 \\
\hline LC-G200-ybbR-1 & 18 & 0.2 & 24618.4 & 25883.9 & $\begin{array}{l}24618.8 \\
25884.4 \\
24638.9\end{array}$ \\
\hline LC-L201-ybbR-1 & 15 & 0.8 & 24618.4 & 25883.9 & 25884 \\
\hline
\end{tabular}

${ }^{a} \mathrm{~S} 6$ and ybbR peptide tags are inserted after the specified residue whose position is labeled according to the Eu numbering system. ${ }^{7}$

${ }^{b}$ Antibody yield per liter of mammalian culture (based on a culture volume of $35 \mathrm{~mL}$ for each construct) as measured after protein A purification.

${ }^{c}$ Drug-to-antibody ratio (DAR) according to RP-HPLC. 
${ }^{d}$ Calculated molecular weight of uncoupled heavy or light chain in Dalton.

${ }^{\mathrm{e}}$ Calculated molecular weight of coupled heavy or light chain in Dalton.

${ }^{f}$ Observed mass in Dalton. Most prominent observation is listed first. Less prominent peaks may be derived from sodium adduct formation or partial maleimide hydrolysis of the ADC drug-linker.

${ }^{g}$ Observed mass corresponds to non-clipped C-terminal lysine residue of heavy chain.

n.d., not determined. Accurate determination of the DAR by RP-HPLC was not possible due to insufficient peak separation.

N/A, not applicable. Conjugation was not attempted or data could not be obtained due to insufficient material.

Table S2. Characterization of 97 peptide-tagged anti-HER2 constructs that were expressed in culture volumes of $200-1000 \mathrm{~mL}$.

\begin{tabular}{|c|c|c|c|c|c|c|}
\hline ADC name ${ }^{a}$ & $\begin{array}{c}\text { Antibody } \\
\text { yield }(\mathrm{mg} / \mathrm{L})^{\mathrm{b}}\end{array}$ & $\begin{array}{l}\text { ADC yield } \\
(\mathrm{mg} / \mathrm{L})^{\mathrm{c}}\end{array}$ & $\operatorname{DAR}^{\mathrm{d}}$ & $\begin{array}{c}\text { Monomer } \\
(\%)^{\mathrm{e}}\end{array}$ & $\begin{array}{l}\text { Expected } \\
\text { mass }(D a)^{f}\end{array}$ & $\begin{array}{c}\text { Observed } \\
\text { mass }(\mathrm{Da})^{9}\end{array}$ \\
\hline HC-E388-S6-1 & 40 & 25 & 2.0 & 100 & 51790.5 & 51792.4 \\
\hline HC-E388-ybbR-1 & 51 & 28 & 1.9 & 100 & 51597.3 & 51592.0 \\
\hline HC-A118-S6-1 & 10 & 4 & 2.0 & 100 & 51790.5 & 51792.2 \\
\hline HC-S119-S6-1 & 57 & 31 & 2.0 & 97 & 51790.5 & 51786.4 \\
\hline HC-T120-S6-1 & 40 & 23 & 2.0 & 100 & 51790.5 & 51796.4 \\
\hline HC-T135-S6-1 & 41 & 20 & 2.0 & 100 & 51790.5 & 51785.2 \\
\hline HC-S136-S6-1 & 40 & 20 & 2.0 & 100 & 51790.5 & 51785.6 \\
\hline HC-G138-S6-1 & 17 & 12 & 2.0 & 100 & 51790.5 & 51790.1 \\
\hline HC-A162-S6-1 & 25 & 16 & 2.0 & 100 & 51790.5 & 51791.6 \\
\hline HC-T164-S6-1 & 32 & 15 & 2.0 & 100 & 51790.5 & 51787.6 \\
\hline HC-S165-S6-1 & 39 & 21 & 2.0 & 100 & 51790.5 & 51786.4 \\
\hline HC-P189-S6-1 & 36 & 25 & 2.0 & 100 & 51790.5 & 51792.0 \\
\hline HC-S191-S6-1 & 43 & 23 & 2.0 & 100 & 51790.5 & 51791.5 \\
\hline HC-S192-S6-1 & 15 & 8 & 2.0 & 100 & 51790.5 & 51791.2 \\
\hline HC-L193-S6-1 & 18 & 10 & 2.0 & 100 & 51790.5 & 51790.8 \\
\hline HC-G194-S6-1 & 35 & 21 & 2.0 & 100 & 51790.5 & 51794.8 \\
\hline HC-T195-S6-1 & 39 & 21 & 1.9 & 100 & 51790.5 & 51790.4 \\
\hline HC-Q196-S6-1 & 27 & 17 & 2.0 & 100 & 51790.5 & 51787.2 \\
\hline HC-P206-S6-1 & 30 & 15 & 1.9 & 100 & 51790.5 & 51790.1 \\
\hline HC-A231-S6-1 & 27 & 12 & 2.0 & 100 & 51790.5 & 51789.6 \\
\hline HC-E233-S6-1 & 4 & 1 & 2.0 & 100 & 51790.5 & 51790.0 \\
\hline HC-L235-S6-1 & 9 & 4 & 2.0 & 100 & 51790.5 & 51789.6 \\
\hline HC-I253-S6-1 & 7 & 3 & 1.9 & 100 & 51790.5 & $\begin{array}{l}51788.9 \\
51729.9^{k}\end{array}$ \\
\hline HC-S254-S6-1 & 23 & 3 & 2.0 & n.d. & 51790.5 & $\begin{array}{c}51788.3 \\
51597.3^{\mathrm{m}} \\
51729.3^{\mathrm{k}}\end{array}$ \\
\hline HC-R255-S6-1 & 20 & 7 & 2.0 & 100 & 51790.5 & $\begin{array}{l}51786.1 \\
51727.9^{k}\end{array}$ \\
\hline HC-S267-S6-1 & 9 & 5 & 2.0 & 100 & 51790.5 & 51788.7 \\
\hline HC-H268-S6-1 & 13 & 6 & 2.0 & 100 & 51790.5 & 51789.1 \\
\hline HC-D270-S6-1 & 17 & 9 & 2.0 & 100 & 51790.5 & 51788.7 \\
\hline HC-P271-S6-1 & 9 & 4 & 1.9 & 100 & 51790.5 & 51782.0 \\
\hline HC-P291-S6-1 & 28 & 16 & 1.9 & 100 & 51790.5 & 51786.8 \\
\hline
\end{tabular}




\begin{tabular}{|c|c|c|c|c|c|c|}
\hline ADC name ${ }^{a}$ & $\begin{array}{c}\text { Antibody } \\
\text { yield }(\mathrm{mg} / \mathrm{L})^{\mathrm{b}}\end{array}$ & $\begin{array}{l}\text { ADC yield } \\
(\mathrm{mg} / \mathrm{L})^{\mathrm{c}}\end{array}$ & DAR $^{d}$ & $\begin{array}{l}\text { Monomer } \\
(\%)^{\mathrm{e}}\end{array}$ & $\begin{array}{l}\text { Expected } \\
\text { mass }(D a)^{f}\end{array}$ & $\begin{array}{l}\text { Observed } \\
\text { mass }(D a)^{g}\end{array}$ \\
\hline HC-A330-S6-1 & 30 & 14 & 1.8 & 100 & 51790.5 & $\begin{array}{c}51796.4 \\
50526.8^{\text {h }} \\
\end{array}$ \\
\hline HC-K340-S6-1 & 20 & 9 & 2.0 & 100 & 51790.5 & $\begin{array}{l}51794.4 \\
51918.4^{i}\end{array}$ \\
\hline HC-G341-S6-1 & 47 & 26 & 1.9 & 100 & 51790.5 & 51794.8 \\
\hline HC-P343-S6-1 & 15 & 6 & 2.0 & 100 & 51790.5 & 51789.2 \\
\hline HC-R344-S6-1 & 37 & 21 & 2.0 & 100 & 51790.5 & 51795.6 \\
\hline HC-K360-S6-1 & 46 & 21 & 1.9 & 100 & 51790.5 & 51785.2 \\
\hline HC-R416-S6-1 & 8 & 4 & 2.0 & 81 & 51790.5 & $\begin{array}{l}51790.9 \\
51917.9\end{array}$ \\
\hline HC-Q418-S6-1 & 55 & 27 & 2.0 & 100 & 51790.5 & $\begin{array}{l}51786.8 \\
51914.4^{i}\end{array}$ \\
\hline HC-N434-S6-1 & 41 & 10 & 1.9 & n.d. & 51790.5 & $\begin{array}{l}51785.2 \\
51912.8^{\mathrm{i}} \\
\end{array}$ \\
\hline HC-P445-S6-1 & 9 & 3 & 1.9 & 100 & 51790.5 & $\begin{array}{l}51783.2 \\
51910.8^{i} \\
\end{array}$ \\
\hline HC-A118-ybbR-1 & 24 & 15 & 1.9 & 100 & 51597.3 & 51595.9 \\
\hline HC-S119-ybbR-1 & 35 & 24 & 1.9 & 100 & 51597.3 & 51591.2 \\
\hline HC-T120-ybbR-1 & 42 & 24 & 1.9 & 100 & 51597.3 & 51592.4 \\
\hline HC-S136-ybbR-1 & 33 & 20 & 1.9 & 100 & 51597.3 & 51602.0 \\
\hline HC-G138-ybbR-1 & 26 & 14 & 1.9 & 100 & 51597.3 & 51592.0 \\
\hline HC-A162-ybbR-1 & 20 & 14 & 1.9 & 100 & 51597.3 & 51596.6 \\
\hline HC-T164-ybbR-1 & 25 & 19 & 2.0 & 100 & 51597.3 & 51597.0 \\
\hline HC-S165-ybbR-1 & 33 & 21 & 1.9 & 100 & 51597.3 & 51595.2 \\
\hline HC-S191-ybbR-1 & 22 & 12 & 2.0 & 100 & 51597.3 & 51596.9 \\
\hline HC-S192-ybbR-1 & 22 & 14 & 2.0 & 100 & 51597.3 & 51597.0 \\
\hline HC-G194-ybbR-1 & 24 & 14 & 1.9 & 100 & 51597.3 & 51592.4 \\
\hline HC-T195-ybbR-1 & 12 & 6 & 2.0 & 100 & 51597.3 & 51597.3 \\
\hline HC-Q196-ybbR-1 & 12 & 7 & 1.9 & 100 & 51597.3 & 51595.9 \\
\hline HC-L235-ybbR-1 & 28 & 18 & 2.0 & 100 & 51597.3 & $\begin{array}{l}51593.9 \\
50407.9^{\prime} \\
\end{array}$ \\
\hline HC-G236-ybbR-1 & 49 & 38 & 1.9 & 100 & 51597.3 & $\begin{array}{l}51595.2 \\
50408.8 \\
\end{array}$ \\
\hline HC-S254-ybbR-1 & 19 & 11 & 2.0 & 100 & 51597.3 & 51595.3 \\
\hline HC-R255-ybbR-1 & 12 & 7 & 2.0 & 100 & 51597.3 & $\begin{array}{l}51595.0 \\
51536.9^{k}\end{array}$ \\
\hline HC-P257-ybbR-1 & 10 & 5 & 2.0 & 100 & 51597.3 & 51595.2 \\
\hline HC-E269-ybbR-1 & 9 & 5 & 1.9 & 100 & 51597.3 & 51595.7 \\
\hline HC-D270-ybbR-1 & 33 & 26 & 1.9 & 100 & 51597.3 & 51595.2 \\
\hline HC-P271-ybbR-1 & 21 & 13 & 1.9 & 100 & 51597.3 & 51594.1 \\
\hline HC-L328-ybbR-1 & 35 & 22 & 1.9 & 100 & 51597.3 & 51600.4 \\
\hline HC-A330-ybbR-1 & 20 & 12 & 1.8 & 100 & 51597.3 & $\begin{array}{l}51589.2 \\
50323.6^{h} \\
\end{array}$ \\
\hline LC-V110-S6-1 & 8 & 3 & 2.0 & 93 & 26077.1 & 26074.8 \\
\hline HC-P343-ybbR-1 & 24 & 15 & 1.9 & 100 & 51597.3 & 51594.6 \\
\hline HC-R344-ybbR-1 & 23 & 13 & 1.9 & 100 & 51597.3 & 51594.6 \\
\hline LC-A111-S6-1 & 20 & 13 & 2.0 & 100 & 26077.1 & 26073.6 \\
\hline HC-N389-ybbR-1 & 23 & 14 & 1.9 & 100 & 51597.3 & 51592.7 \\
\hline HC-R416-ybbR-1 & 22 & 10 & 2.0 & 100 & 51597.3 & $\begin{array}{l}51595.0 \\
51537.0^{\mathrm{k}}\end{array}$ \\
\hline HC-G420-ybbR-1 & 42 & 33 & 2.0 & 100 & 51597.3 & 51595.0 \\
\hline
\end{tabular}




\begin{tabular}{|c|c|c|c|c|c|c|}
\hline ADC name ${ }^{a}$ & $\begin{array}{c}\text { Antibody } \\
\text { yield }(\mathrm{mg} / \mathrm{L})^{\mathrm{b}}\end{array}$ & $\begin{array}{l}\text { ADC yield } \\
(\mathrm{mg} / \mathrm{L})^{c}\end{array}$ & $D_{A} R^{d}$ & $\begin{array}{c}\text { Monomer } \\
(\%)^{\mathrm{e}}\end{array}$ & $\begin{array}{l}\text { Expected } \\
\text { mass }(D a)^{f}\end{array}$ & $\begin{array}{l}\text { Observed } \\
\text { mass }(D a)^{g}\end{array}$ \\
\hline HC-N421-ybbR-1 & 39 & 31 & 2.0 & 100 & 51597.3 & $\begin{array}{l}51596.7 \\
51725.6^{i}\end{array}$ \\
\hline HC-G446-ybbR-1 & 37 & 23 & 1.9 & 100 & 51597.3 & 51590.4 \\
\hline HC-G161-A1-1 & 18 & 9 & 1.9 & 100 & 51800.5 & $\begin{array}{l}51798.3 \\
50533.6^{h}\end{array}$ \\
\hline HC-L163-A1-1 & 22 & 10 & 1.5 & 100 & 51800.5 & $\begin{array}{l}51799.0 \\
50533.8^{h} \\
\end{array}$ \\
\hline HC-S165-A1-1 & 23 & 10 & 1.9 & 100 & 51800.5 & 51799.2 \\
\hline HC-S190-A1-1 & 8 & 4 & 1.8 & 100 & 51800.5 & $\begin{array}{l}51799.3 \\
50534.1^{h}\end{array}$ \\
\hline HC-S191-A1-1 & 14 & 7 & 1.9 & 100 & 51800.5 & 51799.2 \\
\hline HC-S192-A1-1 & 11 & 5 & 1.9 & 100 & 51800.5 & 51799.2 \\
\hline HC-G194-A1-1 & 16 & 9 & 1.9 & 100 & 51800.5 & 51799.0 \\
\hline HC-T195-A1-1 & 25 & 10 & 1.9 & 100 & 51800.5 & 51799.2 \\
\hline LC-T109-A1-1 & 27 & 10 & 1.9 & 100 & 26087.1 & $\begin{array}{l}26085.8 \\
28924.5^{1} \\
\end{array}$ \\
\hline LC-V110-A1-1 & 27 & 10 & 1.9 & 100 & 26087.1 & $\begin{array}{l}26086.0 \\
28924.7^{\prime}\end{array}$ \\
\hline LC-A153-S6-1 & 30 & 22 & 2.0 & 100 & 26077.1 & $\begin{array}{l}26075.7 \\
25456.0^{\prime}\end{array}$ \\
\hline LC-L154-S6-1 & 35 & 27 & 2.0 & 100 & 26077.1 & $\begin{array}{l}26076.8 \\
28925.2 \\
\end{array}$ \\
\hline LC-Q155-S6-1 & 29 & 19 & 1.9 & 100 & 26077.1 & 26070.8 \\
\hline LC-E161-S6-1 & 23 & 15 & 2.0 & 100 & 26077.1 & $\begin{array}{l}26076.5 \\
25457.3\end{array}$ \\
\hline LC-S162-S6-1 & 9 & 6 & 1.9 & 100 & 26077.1 & 26076.0 \\
\hline LC-Q199-S6-1 & 10 & 3 & 1.9 & 100 & 26077.1 & 26074.4 \\
\hline LC-S203-S6-1 & 15 & 6 & 2.0 & 100 & 26077.1 & 26076.7 \\
\hline LC-K207-S6-1 & 9 & 4 & 1.9 & 100 & 26077.1 & 26076.7 \\
\hline LC-V110-ybbR-1 & 53 & 29 & 1.9 & 100 & 25883.9 & 25880.8 \\
\hline LC-A111-ybbR-1 & 12 & 8 & 1.9 & 100 & 25883.9 & $\begin{array}{l}25880.4 \\
25901.2^{\mathrm{j}}\end{array}$ \\
\hline LC-A153-ybbR-1 & 14 & 7 & 1.9 & 100 & 25883.9 & 25878.0 \\
\hline LC-Q155-ybbR-1 & 45 & 35 & 1.9 & 100 & 25883.9 & $\begin{array}{l}25883.0 \\
28925.2^{1}\end{array}$ \\
\hline LC-L201-ybbR-1 & 26 & 15 & 1.8 & 100 & 25883.9 & 25881.2 \\
\hline LC-S202-ybbR-1 & 22 & 13 & 1.9 & 100 & 25883.9 & 25883.6 \\
\hline LC-S203-ybbR-1 & 15 & 8 & 1.9 & 100 & 25883.9 & $\begin{array}{l}25883.5 \\
28925.4 \\
\end{array}$ \\
\hline
\end{tabular}

${ }^{a} \mathrm{~S} 6, \mathrm{ybbR}$, and $\mathrm{A} 1$ peptide tags are inserted after the specified residue whose position is labeled according to the Eu numbering system. ${ }^{7}$

${ }^{b}$ Antibody yield per liter of mammalian culture (based on culture volumes of $200-1000 \mathrm{~mL}$ ) as measured after protein A purification.

${ }^{\mathrm{C}}$ ADC yield per liter of mammalian culture as measured after preparative SEC.

${ }^{d}$ Drug-to-antibody ratio (DAR) according to RP-HPLC.

${ }^{\mathrm{e}}$ Percentage of monomeric ADC as determined by analytical SEC.

${ }^{f}$ Calculated molecular weight of coupled heavy or light chain in Dalton.

${ }^{\mathrm{g}}$ Observed mass in Dalton. Most prominent observation is listed first.

${ }^{\mathrm{h}}$ Observed mass corresponds to non-conjugated heavy chain.

i Observed mass corresponds to non-clipped C-terminal lysine residue of heavy chain. 
j Observed mass most likely corresponds to sodium adduct.

${ }^{k}$ Observed mass corresponds to clipped Gly446 residue of heavy chain.

' Observed mass corresponds to an unknown species of low abundance.

${ }^{m}$ Observed mass most likely derives from carryover of a previously injected sample.

n.d., not determined.

Table S3. Assessment of the thermal stability of trastuzumab and peptide-tagged anti-HER2 antibodies before and after conjugation with compound 1.

\begin{tabular}{|c|c|c|c|c|c|c|c|}
\hline $\begin{array}{c}\text { Antibody/ADC } \\
\text { name }^{\mathrm{a}}\end{array}$ & $\begin{array}{l}\text { Antibody } \\
\operatorname{Tm}_{1}\left({ }^{\circ} \mathrm{C}\right)\end{array}$ & $\begin{array}{l}\text { Antibody } \\
\mathrm{Tm}_{2}\left({ }^{\circ} \mathrm{C}\right)\end{array}$ & $\begin{array}{c}A D C \\
\operatorname{Tm}_{1}\left({ }^{\circ} \mathrm{C}\right)\end{array}$ & $\begin{array}{c}A D C \\
\operatorname{Tm}_{2}\left({ }^{\circ} \mathrm{C}\right)\end{array}$ & $\Delta \operatorname{Tm}_{1}\left({ }^{\circ} \mathrm{C}\right)^{\mathrm{b}}$ & $\Delta \operatorname{Tm}_{2}\left({ }^{\circ} \mathrm{C}\right)^{\mathrm{b}}$ & $\begin{array}{c}A b-W T \\
\Delta \operatorname{Tm}_{1}\left({ }^{\circ} \mathrm{C}\right)^{\mathrm{c}}\end{array}$ \\
\hline trastuzumab & 69.7 & 81.1 & $\mathrm{~N} / \mathrm{A}$ & $\mathrm{N} / \mathrm{A}$ & $\mathrm{N} / \mathrm{A}$ & $\mathrm{N} / \mathrm{A}$ & 0.0 \\
\hline HC-E388-S6-1 & 66.4 & 81.3 & 66.2 & 80.9 & -0.2 & -0.4 & -3.3 \\
\hline HC-E388-ybbR-1 & 69.3 & 81.5 & 68.8 & 81.0 & -0.6 & -0.5 & -0.4 \\
\hline HC-A118-S6-1 & 70.0 & t.b. & 64.6 & 79.0 & -5.3 & t.b. & 0.3 \\
\hline HC-S119-S6-1 & 69.8 & t.b. & 69.2 & t.b. & -0.6 & t.b. & 0.1 \\
\hline HC-T120-S6-1 & 69.1 & t.b. & 68.8 & t.b. & -0.3 & t.b. & -0.6 \\
\hline HC-T135-S6-1 & 67.6 & 81.3 & 67.1 & 81.2 & -0.5 & -0.1 & -2.1 \\
\hline HC-S136-S6-1 & 67.9 & 81.3 & 67.3 & 81.3 & -0.6 & 0 & -1.8 \\
\hline HC-G138-S6-1 & 67.1 & 78.8 & 66.6 & 78.1 & -0.5 & -0.7 & -2.6 \\
\hline HC-A162-S6-1 & 69.3 & 80.0 & 68.9 & 79.8 & -0.3 & -0.2 & -0.5 \\
\hline HC-T164-S6-1 & 68.9 & 80.4 & 68.8 & 80.5 & -0.2 & 0.1 & -0.8 \\
\hline HC-S165-S6-1 & 69.2 & 80.4 & 68.8 & 80.2 & -0.4 & -0.2 & -0.5 \\
\hline HC-P189-S6-1 & 69.0 & 80.5 & 68.3 & 80.4 & -0.7 & -0.2 & -0.7 \\
\hline HC-S191-S6-1 & 66.3 & 77.2 & 65.7 & 77.1 & -0.6 & -0.1 & -3.4 \\
\hline HC-S192-S6-1 & 66.4 & 77.9 & 65.5 & 74.6 & -0.9 & -3.3 & -3.3 \\
\hline HC-L193-S6-1 & 68.0 & 77.1 & 66.7 & 75.9 & -1.3 & -1.2 & -1.7 \\
\hline HC-G194-S6-1 & 68.7 & 80.8 & 67.6 & 80.9 & -1.1 & 0.1 & -1.0 \\
\hline HC-T195-S6-1 & 69.3 & 81.1 & 68.8 & 80.9 & -0.5 & -0.1 & -0.4 \\
\hline HC-Q196-S6-1 & 66.5 & 75.9 & 65.5 & 73.9 & -0.9 & -2.0 & -3.3 \\
\hline HC-P206-S6-1 & 58.8 & 63.4 & 56.1 & 61.9 & -2.7 & -1.6 & -10.9 \\
\hline HC-A231-S6-1 & 60.4 & 79.2 & 69.0 & 75.1 & 8.6 & -4.1 & -9.3 \\
\hline HC-E233-S6-1 & 44.9 & 78.5 & 44.0 & 77.7 & -0.9 & -0.8 & -24.8 \\
\hline HC-L235-S6-1 & 61.1 & 79.3 & 62.3 & 79.1 & 1.2 & -0.2 & -8.6 \\
\hline HC-I253-S6-1 & 50.3 & 79.0 & 46.2 & 78.7 & -4.1 & -0.3 & -19.4 \\
\hline HC-S254-S6-1 & n.d. & n.d. & n.d. & n.d. & n.d. & n.d. & n.d. \\
\hline HC-R255-S6-1 & 52.0 & 76.9 & 49.7 & 78.6 & -2.3 & 1.7 & -17.7 \\
\hline HC-S267-S6-1 & 49.1 & 78.9 & 47.4 & 78.0 & -1.7 & -0.9 & -20.6 \\
\hline HC-H268-S6-1 & 49.8 & 78.9 & 48.1 & 77.6 & -1.6 & -1.3 & -19.9 \\
\hline HC-D270-S6-1 & 67.7 & 75.9 & 43.9 & 77.7 & -23.8 & 1.8 & -2.0 \\
\hline HC-P271-S6-1 & 53.4 & 81.6 & 51.2 & 81.2 & -2.2 & -0.4 & -16.3 \\
\hline HC-P291-S6-1 & 56.0 & 77.3 & 65.4 & 77.9 & 9.4 & 0.6 & -13.7 \\
\hline HC-A330-S6-1 & 52.5 & 81.5 & 49.0 & 81.1 & -3.5 & -0.3 & -17.2 \\
\hline HC-K340-S6-1 & 65.2 & 77.3 & 58.7 & 81.0 & -6.5 & 3.7 & -4.5 \\
\hline HC-G341-S6-1 & 65.0 & 76.9 & 56.0 & 81.0 & -9.0 & 4.2 & -4.7 \\
\hline HC-P343-S6-1 & 56.9 & 79.0 & 55.3 & 78.4 & -1.5 & -0.6 & -12.9 \\
\hline HC-R344-S6-1 & 58.6 & 81.4 & 57.7 & 81.2 & -0.9 & -0.2 & -11.1 \\
\hline HC-K360-S6-1 & 70.1 & 81.7 & 68.8 & 81.4 & -1.3 & -0.3 & 0.3 \\
\hline HC-R416-S6-1 & 63.4 & 78.9 & 66.7 & 78.4 & 3.3 & -0.6 & -6.3 \\
\hline
\end{tabular}




\begin{tabular}{|c|c|c|c|c|c|c|c|}
\hline $\begin{array}{c}\text { Antibody/ADC } \\
\text { name }^{\mathrm{a}}\end{array}$ & $\begin{array}{l}\text { Antibody } \\
\operatorname{Tm}_{1}\left({ }^{\circ} \mathrm{C}\right)\end{array}$ & $\begin{array}{l}\text { Antibody } \\
\mathrm{Tm}_{2}\left({ }^{\circ} \mathrm{C}\right)\end{array}$ & $\begin{array}{c}A D C \\
\operatorname{Tm}_{1}\left({ }^{\circ} \mathrm{C}\right)\end{array}$ & $\begin{array}{c}\mathrm{ADC} \\
\operatorname{Tm}_{2}\left({ }^{\circ} \mathrm{C}\right)\end{array}$ & $\Delta \operatorname{Tm}_{1}\left({ }^{\circ} \mathrm{C}\right)^{\mathrm{b}}$ & $\Delta \operatorname{Tm}_{2}\left({ }^{\circ} \mathrm{C}\right)^{\mathrm{b}}$ & $\begin{array}{c}A b-W T \\
\Delta \operatorname{Tm}_{1}\left({ }^{\circ} \mathrm{C}\right)^{\mathrm{c}}\end{array}$ \\
\hline HC-Q418-S6-1 & 69.0 & 81.0 & 68.3 & 81.1 & -0.7 & 0.1 & -0.7 \\
\hline HC-N434-S6-1 & 60.5 & 81.5 & n.d. & n.d. & n.d. & n.d. & -9.2 \\
\hline HC-P445-S6-1 & 71.8 & 81.0 & 69.9 & 80.5 & -1.8 & -0.5 & 2.1 \\
\hline HC-A118-ybbR-1 & 68.1 & t.b. & 67.8 & t.b. & -0.3 & t.b. & -1.6 \\
\hline HC-S119-ybbR-1 & 70.1 & t.b. & 71.2 & t.b. & 1.0 & t.b. & 0.4 \\
\hline HC-T120-ybbR-1 & 70.4 & t.b. & 70.4 & t.b. & 0 & t.b. & 0.7 \\
\hline HC-S136-ybbR-1 & 69.3 & 80.8 & 68.3 & 81.0 & -1.1 & 0.2 & -0.4 \\
\hline HC-G138-ybbR-1 & 69.3 & 80.9 & 68.5 & 81.2 & -0.7 & 0.2 & -0.4 \\
\hline HC-A162-ybbR-1 & 69.0 & 78.2 & 68.1 & 76.4 & -0.9 & -1.7 & -0.7 \\
\hline HC-T164-ybbR-1 & 69.0 & 78.3 & 68.1 & 77.4 & -0.9 & -1.0 & -0.7 \\
\hline HC-S165-ybbR-1 & 69.6 & 80.3 & 69.2 & 80.5 & -0.4 & 0.1 & -0.1 \\
\hline HC-S191-ybbR-1 & 68.3 & 77.8 & 66.8 & 74.9 & -1.5 & -2.9 & -1.4 \\
\hline HC-S192-ybbR-1 & 68.4 & 78.1 & 66.9 & 76.1 & -1.4 & -1.9 & -1.3 \\
\hline HC-G194-ybbR-1 & 69.3 & 81.1 & 68.5 & 80.9 & -0.9 & -0.1 & -0.4 \\
\hline HC-T195-ybbR-1 & 68.4 & 77.7 & 66.8 & 75.5 & -1.6 & -2.2 & -1.3 \\
\hline HC-Q196-ybbR-1 & 68.2 & 77.3 & 68.2 & 77.3 & 0 & 0 & -1.5 \\
\hline HC-L235-ybbR-1 & 64.1 & 79.4 & 63.5 & 78.9 & -0.6 & -0.5 & -5.6 \\
\hline HC-G236-ybbR-1 & 66.2 & 79.3 & 63.1 & 78.8 & -3.1 & -0.5 & -3.5 \\
\hline HC-S254-ybbR-1 & 57.9 & 79.2 & 53.3 & 78.5 & -4.5 & -0.7 & -11.8 \\
\hline HC-R255-ybbR-1 & 58.4 & 79.3 & 54.4 & 78.7 & -4.1 & -0.5 & -11.3 \\
\hline HC-P257-ybbR-1 & 59.9 & 75.9 & 66.8 & 74.8 & 6.9 & -1.2 & -9.8 \\
\hline HC-E269-ybbR-1 & 53.9 & 79.4 & 69.4 & t.b. & 15.5 & t.b. & -15.8 \\
\hline HC-D270-ybbR-1 & 53.7 & 79.6 & 51.3 & 77.9 & -2.4 & -1.7 & -16.0 \\
\hline HC-P271-ybbR-1 & 53.0 & 79.8 & 49.8 & 78.0 & -3.1 & -1.8 & -16.7 \\
\hline HC-L328-ybbR-1 & 56.9 & 78.8 & 50.4 & 81.0 & -6.5 & 2.1 & -12.8 \\
\hline HC-A330-ybbR-1 & 54.2 & 81.1 & 51.3 & 81.2 & -2.9 & 0.1 & -15.5 \\
\hline LC-V110-S6-1 & 66.9 & t.b. & 66.3 & t.b. & -0.6 & t.b. & -2.8 \\
\hline HC-P343-ybbR-1 & 59.5 & 79.2 & 57.6 & 78.7 & -1.8 & -0.5 & -10.2 \\
\hline HC-R344-ybbR-1 & 60.5 & 79.2 & 58.4 & 78.6 & -2.1 & -0.5 & -9.2 \\
\hline LC-A111-S6-1 & 67.3 & t.b. & 66.0 & t.b. & -1.3 & t.b. & -2.4 \\
\hline HC-N389-ybbR-1 & 67.8 & 79.1 & 67.3 & 78.7 & -0.5 & -0.5 & -1.9 \\
\hline HC-R416-ybbR-1 & 67.5 & 78.8 & 66.8 & 78.5 & -0.8 & -0.3 & -2.2 \\
\hline HC-G420-ybbR-1 & 67.9 & 78.9 & 67.3 & 78.4 & -0.6 & -0.6 & -1.8 \\
\hline HC-N421-ybbR-1 & 68.9 & t.b. & 68.1 & 77.4 & -0.7 & t.b. & -0.9 \\
\hline HC-G446-ybbR-1 & 69.9 & 81.2 & 69.9 & 80.9 & 0 & -0.4 & 0.2 \\
\hline HC-G161-A1-1 & 68.9 & 78.2 & 67.7 & 75.9 & -1.1 & -2.3 & -0.8 \\
\hline HC-L163-A1-1 & 69.0 & 78.4 & 68.3 & 77.5 & -0.8 & -0.9 & -0.7 \\
\hline HC-S165-A1-1 & 69.1 & 78.7 & 68.1 & 77.5 & -1.0 & -1.3 & -0.6 \\
\hline HC-S190-A1-1 & 68.0 & 78.0 & 66.6 & 76.6 & -1.4 & -1.5 & -1.7 \\
\hline HC-S191-A1-1 & 68.0 & 78.1 & 66.5 & 76.2 & -1.5 & -2.0 & -1.7 \\
\hline HC-S192-A1-1 & 68.1 & 78.4 & 66.7 & 76.4 & -1.4 & -1.9 & -1.6 \\
\hline HC-G194-A1-1 & 68.3 & 78.4 & 66.9 & 76.7 & -1.4 & -1.7 & -1.4 \\
\hline HC-T195-A1-1 & 68.3 & 77.9 & 66.9 & 75.8 & -1.4 & -2.1 & -1.4 \\
\hline LC-T109-A1-1 & 66.5 & t.b. & 64.3 & t.b. & -2.2 & t.b. & -3.2 \\
\hline LC-V110-A1-1 & 66.1 & t.b. & 63.8 & t.b. & -2.3 & t.b. & -3.6 \\
\hline LC-A153-S6-1 & & 77.8 & 66.7 & 76.1 & & -1.6 & \\
\hline LC-L154-S6-1 & 68.9 & 77.2 & 67.6 & 75.9 & -1.2 & -1.3 & -0.9 \\
\hline LC-Q155-S6-1 & 69.4 & 80.0 & 68.7 & 79.4 & -0.7 & -0.6 & -0.3 \\
\hline
\end{tabular}




\begin{tabular}{|c|c|c|c|c|c|c|c|}
\hline $\begin{array}{c}\text { Antibody/ADC } \\
\text { name }^{\mathrm{a}}\end{array}$ & $\begin{array}{l}\text { Antibody } \\
\operatorname{Tm}_{1}\left({ }^{\circ} \mathrm{C}\right)\end{array}$ & $\begin{array}{l}\text { Antibody } \\
\mathrm{Tm}_{2}\left({ }^{\circ} \mathrm{C}\right)\end{array}$ & $\begin{array}{c}A D C \\
\operatorname{Tm}_{1}\left({ }^{\circ} \mathrm{C}\right)\end{array}$ & $\begin{array}{c}A D C \\
\operatorname{Tm}_{2}\left({ }^{\circ} \mathrm{C}\right)\end{array}$ & $\Delta \operatorname{Tm}_{1}\left({ }^{\circ} \mathbf{C}\right)^{\mathrm{b}}$ & $\Delta \mathrm{Tm}_{2}\left({ }^{\circ} \mathrm{C}\right)^{\mathrm{b}}$ & $\begin{array}{c}A b-W T \\
\Delta \operatorname{Tm}_{1}\left({ }^{\circ} \mathrm{C}\right)^{\mathrm{c}}\end{array}$ \\
\hline LC-E161-S6-1 & 70.1 & 75.8 & 67.4 & t.b. & -2.7 & t.b. & 0.4 \\
\hline LC-S162-S6-1 & 68.5 & t.b. & 67.3 & t.b. & -1.2 & t.b. & -1.2 \\
\hline LC-Q199-S6-1 & 67.5 & t.b. & 67.4 & t.b. & -0.1 & t.b. & -2.2 \\
\hline LC-S203-S6-1 & 66.6 & t.b. & 65.4 & t.b. & -1.3 & t.b. & -3.1 \\
\hline LC-K207-S6-1 & 65.4 & t.b. & 62.8 & t.b. & -2.6 & t.b. & -4.3 \\
\hline LC-V110-ybbR-1 & 69.0 & t.b. & 67.6 & t.b. & -1.4 & t.b. & -0.7 \\
\hline LC-A111-ybbR-1 & 69.6 & t.b. & 68.5 & t.b. & -1.1 & t.b. & -0.1 \\
\hline LC-A153-ybbR-1 & 69.6 & 79.7 & 69.0 & 79.2 & -0.5 & -0.5 & -0.1 \\
\hline LC-Q155-ybbR-1 & 69.3 & 77.1 & 68.3 & 76.0 & -1.0 & -1.2 & -0.4 \\
\hline LC-L201-ybbR-1 & 69.5 & 75.1 & 68.7 & 74.8 & -0.8 & -0.4 & -0.2 \\
\hline LC-S202-ybbR-1 & 68.6 & t.b. & 66.9 & t.b. & -1.8 & t.b. & -1.1 \\
\hline LC-S203-ybbR-1 & 68.9 & 74.0 & 66.4 & t.b. & -2.5 & t.b. & -0.8 \\
\hline
\end{tabular}

${ }^{a} \mathrm{~S} 6, \mathrm{ybbR}$, and A1 peptide tags are inserted after the specified residue whose position is labeled according to the Eu numbering system. ${ }^{7}$

${ }^{\mathrm{b}} \mathrm{Tm}_{1}$ or $\mathrm{Tm}_{2}$ of $\mathrm{ADC}$ subtracted by the corresponding value of the uncoupled antibody.

${ }^{\mathrm{c}} \mathrm{Tm}_{1}$ of uncoupled antibody subtracted by the respective value of unmodified trastuzumab $\left(69.7^{\circ} \mathrm{C}\right)$.

n.d., not determined. Measurement was not performed due to insufficient sample amounts.

t.b., transition too broad for accurate determination of $\mathrm{Tm}_{2}$.

N/A, not applicable.

Table S4. In vitro potency assessment of peptide-tagged anti-HER2 ADCs.

\begin{tabular}{|c|c|c|c|c|}
\hline ADC name ${ }^{a}$ & $\begin{array}{l}\text { MDA-MB-231 } \\
\text { clone } 40 \\
\text { IC }_{50}(\mu \mathrm{M})^{\mathrm{b}}\end{array}$ & $\begin{array}{l}\text { HCC1954 } \\
\text { IC }_{50}(\mu \mathrm{M})^{\mathrm{b}}\end{array}$ & $\begin{array}{c}\text { JIMT-1 } \\
\text { IC }_{50}(\mu \mathrm{M})^{\mathrm{b}}\end{array}$ & $\begin{array}{l}\text { MDA-MB-231 } \\
\text { clone } 16 \\
\text { IC }_{50}(\mu \mathrm{M})^{\mathrm{b}}\end{array}$ \\
\hline HC-E388-S6-1 & 3.33E-02 & 1.57E-04 & $4.21 \mathrm{E}-04$ & 5.42E-04 \\
\hline HC-E388-ybbR-1 & 3.33E-02 & $2.26 \mathrm{E}-04$ & $1.83 \mathrm{E}-03$ & $3.12 \mathrm{E}-04$ \\
\hline HC-A118-S6-1 & $3.33 E-02$ & $2.57 \mathrm{E}-04$ & $6.74 \mathrm{E}-04$ & 1.95E-04 \\
\hline HC-S119-S6-1 & 3.33E-02 & $1.94 \mathrm{E}-04$ & $5.10 \mathrm{E}-04$ & $6.82 \mathrm{E}-04$ \\
\hline HC-T120-S6-1 & 3.33E-02 & $1.69 \mathrm{E}-04$ & 7.53E-04 & $7.02 \mathrm{E}-04$ \\
\hline HC-T135-S6-1 & 3.33E-02 & $1.36 \mathrm{E}-04$ & $2.57 \mathrm{E}-04$ & $3.10 \mathrm{E}-04$ \\
\hline HC-S136-S6-1 & 3.33E-02 & 1.64E-04 & $2.43 \mathrm{E}-04$ & 3.05E-04 \\
\hline HC-G138-S6-1 & $3.33 \mathrm{E}-02$ & $2.44 \mathrm{E}-04$ & $3.16 \mathrm{E}-04$ & $1.78 \mathrm{E}-04$ \\
\hline HC-A162-S6-1 & 3.33E-02 & $1.55 \mathrm{E}-04$ & 8.66E-04 & 3.31E-04 \\
\hline HC-T164-S6-1 & 3.33E-02 & 1.89E-04 & 5.36E-04 & 4.69E-04 \\
\hline HC-S165-S6-1 & 3.33E-02 & 1.69E-04 & $6.19 \mathrm{E}-04$ & $4.00 \mathrm{E}-04$ \\
\hline HC-P189-S6-1 & 3.33E-02 & 1.47E-04 & 2.69E-04 & $2.86 \mathrm{E}-04$ \\
\hline HC-S191-S6-1 & 3.33E-02 & $2.35 \mathrm{E}-04$ & $3.10 \mathrm{E}-04$ & $1.81 \mathrm{E}-04$ \\
\hline HC-S192-S6-1 & $3.25 \mathrm{E}-02$ & $2.53 \mathrm{E}-04$ & $3.41 \mathrm{E}-04$ & $1.81 \mathrm{E}-04$ \\
\hline HC-L193-S6-1 & 3.33E-02 & $2.10 \mathrm{E}-04$ & 3.03E-04 & 7.99E-05 \\
\hline HC-G194-S6-1 & 3.33E-02 & 1.03E-04 & 1.33E-03 & 3.56E-04 \\
\hline HC-T195-S6-1 & 3.33E-02 & 1.42E-04 & $3.00 \mathrm{E}-04$ & 2.79E-04 \\
\hline HC-Q196-S6-1 & $2.26 \mathrm{E}-02$ & $2.49 \mathrm{E}-04$ & $2.69 \mathrm{E}-04$ & $1.81 \mathrm{E}-04$ \\
\hline HC-P206-S6-1 & 3.33E-02 & $2.68 \mathrm{E}-04$ & $9.11 \mathrm{E}-04$ & 1.79E-04 \\
\hline HC-A231-S6-1 & 3.33E-02 & 2.32E-04 & $2.70 \mathrm{E}-04$ & $1.72 \mathrm{E}-04$ \\
\hline
\end{tabular}




\begin{tabular}{|c|c|c|c|c|}
\hline ADC name ${ }^{a}$ & $\begin{array}{l}\text { MDA-MB-231 } \\
\text { clone } 40 \\
\text { IC }_{50}(\mu \mathrm{M})^{\mathrm{b}}\end{array}$ & $\begin{array}{l}\text { HCC1954 } \\
\text { IC }_{50}(\mu \mathrm{M})^{\mathrm{b}}\end{array}$ & $\begin{array}{c}\text { JIMT-1 } \\
\text { IC }_{50}(\mu \mathrm{M})^{\mathrm{b}}\end{array}$ & $\begin{array}{c}\text { MDA-MB-231 } \\
\text { clone } 16 \\
\text { IC }_{50}(\mu \mathrm{M})^{\mathrm{b}}\end{array}$ \\
\hline HC-E233-S6-1 & 3.33E-02 & $2.43 \mathrm{E}-04$ & $4.47 \mathrm{E}-04$ & $1.01 \mathrm{E}-04$ \\
\hline HC-L235-S6-1 & 3.33E-02 & 2.43E-04 & 3.09E-04 & 1.44E-04 \\
\hline HC-I253-S6-1 & n.d. & n.d. & n.d. & n.d. \\
\hline HC-S254-S6-1 & n.d. & n.d. & n.d. & n.d. \\
\hline HC-R255-S6-1 & 3.33E-02 & 2.06E-04 & 3.67E-04 & 1.16E-04 \\
\hline HC-S267-S6-1 & 3.33E-02 & $2.30 \mathrm{E}-04$ & $3.68 \mathrm{E}-04$ & $8.13 \mathrm{E}-05$ \\
\hline HC-H268-S6-1 & 3.33E-02 & $2.26 \mathrm{E}-04$ & 3.79E-04 & 8.97E-05 \\
\hline HC-D270-S6-1 & 3.33E-02 & $2.28 \mathrm{E}-04$ & $3.41 \mathrm{E}-04$ & 8.89E-05 \\
\hline HC-P271-S6-1 & 3.33E-02 & 1.33E-04 & $4.50 \mathrm{E}-04$ & $6.75 \mathrm{E}-04$ \\
\hline HC-P291-S6-1 & 3.33E-02 & 1.99E-04 & 3.04E-04 & 9.74E-05 \\
\hline HC-A330-S6-1 & 3.33E-02 & 9.68E-05 & $3.18 \mathrm{E}-04$ & 4.66E-04 \\
\hline HC-K340-S6-1 & 3.33E-02 & 3.76E-04 & 5.55E-04 & $3.08 \mathrm{E}-04$ \\
\hline HC-G341-S6-1 & 3.33E-02 & $7.21 \mathrm{E}-05$ & $3.58 \mathrm{E}-04$ & 7.82E-04 \\
\hline HC-P343-S6-1 & 3.33E-02 & 2.27E-04 & 3.88E-04 & 6.27E-05 \\
\hline HC-R344-S6-1 & 3.33E-02 & $2.13 \mathrm{E}-03$ & 4.47E-04 & $3.21 \mathrm{E}-04$ \\
\hline HC-K360-S6-1 & 3.33E-02 & \begin{tabular}{|c|}
$1.80 \mathrm{E}-04$ \\
\end{tabular} & $1.31 \mathrm{E}-03$ & 7.57E-04 \\
\hline HC-R416-S6-1 & 3.03E-02 & $6.68 \mathrm{E}-04$ & $8.65 \mathrm{E}-04$ & $2.69 \mathrm{E}-04$ \\
\hline HC-Q418-S6-1 & 3.33E-02 & $2.48 \mathrm{E}-04$ & $1.24 \mathrm{E}-03$ & 7.31E-04 \\
\hline HC-N434-S6-1 & n.d. & n.d. & n.d. & n.d. \\
\hline HC-P445-S6-1 & 3.33E-02 & 7.42E-05 & 3.84E-03 & 7.44E-04 \\
\hline HC-A118-ybbR-1 & 3.33E-02 & $2.41 \mathrm{E}-04$ & 3.39E-04 & 1.97E-04 \\
\hline HC-S119-ybbR-1 & 3.33E-02 & $1.80 \mathrm{E}-04$ & $3.46 \mathrm{E}-04$ & $3.21 \mathrm{E}-04$ \\
\hline HC-T120-ybbR-1 & 3.33E-02 & 1.98E-04 & $4.59 \mathrm{E}-04$ & 3.94E-04 \\
\hline HC-S136-ybbR-1 & 3.33E-02 & 6.48E-05 & 3.95E-04 & 2.62E-04 \\
\hline HC-G138-ybbR-1 & 3.33E-02 & 1.58E-04 & 3.33E-02 & $3.21 \mathrm{E}-04$ \\
\hline HC-A162-ybbR-1 & 3.33E-02 & 2.27E-04 & 3.42E-04 & $1.24 \mathrm{E}-04$ \\
\hline HC-T164-ybbR-1 & 3.33E-02 & 1.64E-04 & 3.00E-04 & $1.22 \mathrm{E}-04$ \\
\hline HC-S165-ybbR-1 & 3.33E-02 & 1.65E-04 & 4.07E-04 & 3.79E-04 \\
\hline HC-S191-ybbR-1 & 3.33E-02 & $2.39 \mathrm{E}-04$ & $3.21 \mathrm{E}-04$ & $1.49 \mathrm{E}-04$ \\
\hline HC-S192-ybbR-1 & 3.33E-02 & $2.30 \mathrm{E}-04$ & 3.37E-04 & 1.47E-04 \\
\hline HC-G194-ybbR-1 & 3.33E-02 & $1.22 \mathrm{E}-04$ & $6.48 \mathrm{E}-04$ & 1.83E-04 \\
\hline HC-T195-ybbR-1 & $2.90 \mathrm{E}-02$ & \begin{tabular}{|l|}
$1.91 \mathrm{E}-04$ \\
\end{tabular} & $3.14 \mathrm{E}-04$ & $1.31 \mathrm{E}-04$ \\
\hline HC-Q196-ybbR-1 & 3.33E-02 & 2.44E-04 & $4.28 \mathrm{E}-04$ & 1.13E-04 \\
\hline HC-L235-ybbR-1 & 3.33E-02 & 1.90E-04 & 2.97E-04 & $6.48 \mathrm{E}-05$ \\
\hline HC-G236-ybbR-1 & 3.33E-02 & $2.37 \mathrm{E}-04$ & $1.75 \mathrm{E}-03$ & $1.30 \mathrm{E}-04$ \\
\hline HC-S254-ybbR-1 & 3.33E-02 & \begin{tabular}{|l|}
$1.92 \mathrm{E}-04$ \\
\end{tabular} & $5.49 \mathrm{E}-04$ & $6.43 \mathrm{E}-05$ \\
\hline HC-R255-ybbR-1 & 3.33E-02 & 2.06E-04 & 4.33E-04 & $4.40 \mathrm{E}-05$ \\
\hline HC-P257-ybbR-1 & 3.33E-02 & $2.20 \mathrm{E}-04$ & 5.53E-04 & 7.67E-05 \\
\hline HC-E269-ybbR-1 & 3.33E-02 & 2.33E-04 & 3.97E-04 & $1.13 \mathrm{E}-04$ \\
\hline HC-D270-ybbR-1 & 3.33E-02 & 2.47E-04 & $4.49 \mathrm{E}-04$ & 1.87E-04 \\
\hline HC-P271-ybbR-1 & 3.33E-02 & $2.21 \mathrm{E}-04$ & $3.78 \mathrm{E}-04$ & $7.46 \mathrm{E}-05$ \\
\hline HC-L328-ybbR-1 & 3.33E-02 & 1.37E-04 & $2.79 \mathrm{E}-04$ & $1.15 \mathrm{E}-03$ \\
\hline HC-A330-ybbR-1 & 3.33E-02 & 4.09E-04 & $2.24 \mathrm{E}-02$ & 2.85E-04 \\
\hline LC-V110-S6-1 & 3.33E-02 & $2.31 \mathrm{E}-04$ & $4.14 \mathrm{E}-04$ & $5.18 \mathrm{E}-04$ \\
\hline HC-P343-ybbR-1 & 3.33E-02 & $2.40 \mathrm{E}-04$ & 3.75E-04 & 7.55E-05 \\
\hline HC-R344-ybbR-1 & 3.33E-02 & $2.31 \mathrm{E}-04$ & 3.39E-04 & $6.45 \mathrm{E}-05$ \\
\hline LC-A111-S6-1 & 3.33E-02 & $1.95 \mathrm{E}-04$ & $1.15 \mathrm{E}-02$ & $5.05 \mathrm{E}-04$ \\
\hline HC-N389-ybbR-1 & 3.33E-02 & $2.32 \mathrm{E}-04$ & 4.93E-04 & $2.26 \mathrm{E}-04$ \\
\hline
\end{tabular}




\begin{tabular}{|c|c|c|c|c|}
\hline ADC name ${ }^{a}$ & $\begin{array}{c}\text { MDA-MB-231 } \\
\text { clone } 40 \\
\text { IC }_{50}(\mu \mathrm{M})^{\mathrm{b}}\end{array}$ & $\begin{array}{l}\text { HCC1954 } \\
\text { IC }_{50}(\mu \mathrm{M})^{\mathrm{b}}\end{array}$ & $\begin{array}{c}\text { JIMT-1 } \\
\text { IC }_{50}(\mu \mathrm{M})^{\mathrm{b}}\end{array}$ & $\begin{array}{l}\text { MDA-MB-231 } \\
\text { clone } 16 \\
\text { IC }_{50}(\mu \mathrm{M})^{\mathrm{b}}\end{array}$ \\
\hline HC-R416-ybbR-1 & 3.33E-02 & 2.69E-04 & 7.57E-04 & 8.06E-05 \\
\hline HC-G420-ybbR-1 & 3.33E-02 & 2.47E-04 & 7.03E-04 & 1.56E-04 \\
\hline HC-N421-ybbR-1 & $3.33 \mathrm{E}-02$ & $2.47 \mathrm{E}-04$ & $2.27 \mathrm{E}-02$ & $1.59 \mathrm{E}-04$ \\
\hline HC-G446-ybbR-1 & 3.33E-02 & $2.12 \mathrm{E}-04$ & 6.82E-04 & 7.77E-04 \\
\hline HC-G161-A1-1 & 3.33E-02 & $2.28 \mathrm{E}-04$ & $3.48 \mathrm{E}-04$ & 1.63E-04 \\
\hline HC-L163-A1-1 & 3.33E-02 & 2.72E-04 & 3.33E-02 & $2.21 \mathrm{E}-04$ \\
\hline HC-S165-A1-1 & 3.33E-02 & $2.54 \mathrm{E}-04$ & $4.88 \mathrm{E}-04$ & 1.95E-04 \\
\hline HC-S190-A1-1 & $3.33 \mathrm{E}-02$ & $2.58 \mathrm{E}-04$ & $7.20 \mathrm{E}-04$ & $1.69 \mathrm{E}-04$ \\
\hline HC-S191-A1-1 & 3.33E-02 & $2.45 \mathrm{E}-04$ & $3.68 \mathrm{E}-04$ & 1.84E-04 \\
\hline HC-S192-A1-1 & 3.33E-02 & $2.58 \mathrm{E}-04$ & 4.76E-04 & 1.57E-04 \\
\hline HC-G194-A1-1 & 3.33E-02 & $2.51 \mathrm{E}-04$ & 4.93E-04 & 1.67E-04 \\
\hline HC-T195-A1-1 & 3.33E-02 & $2.44 \mathrm{E}-04$ & 4.39E-04 & 1.36E-04 \\
\hline LC-T109-A1-1 & 3.33E-02 & $2.12 \mathrm{E}-04$ & $3.19 \mathrm{E}-04$ & $1.26 \mathrm{E}-04$ \\
\hline LC-V110-A1-1 & 3.33E-02 & $2.24 \mathrm{E}-04$ & $3.54 \mathrm{E}-04$ & 1.60E-04 \\
\hline LC-A153-S6-1 & 3.33E-02 & $2.44 \mathrm{E}-04$ & $3.95 E-04$ & 1.42E-04 \\
\hline LC-L154-S6-1 & 3.33E-02 & $2.48 \mathrm{E}-04$ & 4.57E-04 & 1.26E-04 \\
\hline LC-Q155-S6-1 & 3.33E-02 & $1.43 \mathrm{E}-04$ & $5.47 \mathrm{E}-04$ & 3.70E-04 \\
\hline LC-E161-S6-1 & 3.33E-02 & 1.63E-04 & 2.74E-04 & $1.39 \mathrm{E}-04$ \\
\hline LC-S162-S6-1 & 3.33E-02 & 2.67E-04 & $8.13 E-04$ & 7.14E-04 \\
\hline LC-Q199-S6-1 & 3.33E-02 & $1.92 \mathrm{E}-04$ & $9.21 \mathrm{E}-04$ & 4.77E-04 \\
\hline LC-S203-S6-1 & 3.33E-02 & 2.32E-04 & 4.29E-04 & $1.28 \mathrm{E}-04$ \\
\hline LC-K207-S6-1 & $1.49 \mathrm{E}-02$ & $2.23 \mathrm{E}-04$ & 4.54E-04 & $1.78 \mathrm{E}-04$ \\
\hline LC-V110-ybbR-1 & 3.33E-02 & 3.97E-04 & 4.62E-04 & 2.77E-04 \\
\hline LC-A111-ybbR-1 & 3.33E-02 & 1.59E-04 & 6.32E-04 & 1.68E-02 \\
\hline LC-A153-ybbR-1 & 3.33E-02 & $1.80 \mathrm{E}-04$ & 2.03E-02 & $2.60 \mathrm{E}-04$ \\
\hline LC-Q155-ybbR-1 & 3.33E-02 & $2.21 \mathrm{E}-04$ & $4.48 \mathrm{E}-04$ & 1.70E-04 \\
\hline LC-L201-ybbR-1 & 3.33E-02 & $4.25 \mathrm{E}-04$ & $3.86 \mathrm{E}-04$ & $4.74 \mathrm{E}-04$ \\
\hline LC-S202-ybbR-1 & 3.33E-02 & $2.41 \mathrm{E}-04$ & 4.33E-04 & $1.82 \mathrm{E}-04$ \\
\hline LC-S203-ybbR-1 & $3.33 E-02$ & $2.20 \mathrm{E}-04$ & 3.33E-04 & $1.84 \mathrm{E}-04$ \\
\hline
\end{tabular}

${ }^{a} \mathrm{~S} 6, \mathrm{ybbR}$, and $\mathrm{A} 1$ peptide tags are inserted after the specified residue whose position is labeled according to the Eu numbering system. ${ }^{7}$

${ }^{\mathrm{b}} 33.3 \mathrm{nM}$ was the highest concentration used in the $\mathrm{IC}_{50}$ cell killing assay.

n.d., not determined.

Table S5. Pharmacokinetic profiling of trastuzumab and a library of 95 peptide-tagged anti-HER2 ADCs in non-tumor bearing mice.

\begin{tabular}{|c|c|c|c|c|}
\hline $\begin{array}{c}\text { Antibody/ADC } \\
\text { name }^{\mathrm{a}}\end{array}$ & $\begin{array}{l}\text { Antibody domain with } \\
\text { peptide tag insertion }\end{array}$ & $\begin{array}{c}\operatorname{AUC}^{b} h l g G \\
\left(n M^{\star} h\right)\end{array}$ & $\begin{array}{c}\text { AUC }^{c} \\
\text { auristatin } \\
\left(\mathrm{nM}^{*} \mathrm{~h}\right)\end{array}$ & $\begin{array}{c}\text { AUC(auristatin)/ } \\
\text { AUC(hlgG) }\end{array}$ \\
\hline trastuzumab & $N / A$ & 15796 & $N / A$ & $\mathrm{~N} / \mathrm{A}$ \\
\hline HC-A118-S6-1 & $\mathrm{CH} 1$ & 14235 & 12465 & 0.9 \\
\hline HC-A118-ybbR-1 & $\mathrm{CH} 1$ & 22713 & 19408 & 0.9 \\
\hline HC-S119-S6-1 & $\mathrm{CH} 1$ & 22485 & 21693 & 1.0 \\
\hline
\end{tabular}




\begin{tabular}{|c|c|c|c|c|}
\hline $\begin{array}{l}\text { Antibody/ADC } \\
\text { name }^{a}\end{array}$ & $\begin{array}{l}\text { Antibody domain with } \\
\text { peptide tag insertion }\end{array}$ & $\begin{array}{l}\text { AUC }{ }^{b} h l g G \\
\left(n M^{\star} h\right)\end{array}$ & 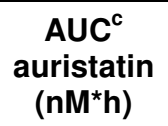 & $\begin{array}{l}\text { AUC(auristatin)/ } \\
\text { AUC(hlgG) }\end{array}$ \\
\hline HC-S119-ybbR-1 & $\mathrm{CH} 1$ & 22854 & 24551 & 1.1 \\
\hline HC-T120-S6-1 & $\mathrm{CH} 1$ & 13880 & 12542 & 0.9 \\
\hline HC-T120-ybbR-1 & $\mathrm{CH} 1$ & 21689 & 19734 & 0.9 \\
\hline HC-T135-S6-1 & $\mathrm{CH} 1$ & 21494 & 16931 & 0.8 \\
\hline HC-S136-S6-1 & $\mathrm{CH} 1$ & 22833 & 23533 & 1.0 \\
\hline HC-S136-ybbR-1 & $\mathrm{CH} 1$ & 27232 & 24064 & 0.9 \\
\hline HC-G138-S6-1 & $\mathrm{CH} 1$ & 21276 & 24046 & 1.1 \\
\hline HC-G138-ybbR-1 & $\mathrm{CH} 1$ & 17184 & 15404 & 0.9 \\
\hline HC-G161-A1-1 & $\mathrm{CH} 1$ & 20297 & 29125 & 1.4 \\
\hline HC-A162-S6-1 & $\mathrm{CH} 1$ & 11178 & 10981 & 1.0 \\
\hline HC-A162-ybbR-1 & $\mathrm{CH} 1$ & 26501 & 27992 & 1.1 \\
\hline HC-L163-A1-1 & $\mathrm{CH} 1$ & n.d. & n.d. & n.d. \\
\hline HC-T164-S6-1 & $\mathrm{CH} 1$ & 20916 & 22125 & 1.1 \\
\hline HC-T164-ybbR-1 & $\mathrm{CH} 1$ & 23675 & 24973 & 1.1 \\
\hline HC-S165-A1-1 & $\mathrm{CH} 1$ & 21008 & 23328 & 1.1 \\
\hline HC-S165-S6-1 & $\mathrm{CH} 1$ & 23242 & 21304 & 0.9 \\
\hline HC-S165-ybbR-1 & $\mathrm{CH} 1$ & 12794 & 13854 & 1.1 \\
\hline HC-P189-S6-1 & $\mathrm{CH} 1$ & 8922 & 8840 & 1.0 \\
\hline HC-S190-A1-1 & $\mathrm{CH} 1$ & n.d. & n.d. & n.d. \\
\hline HC-S191-A1-1 & $\mathrm{CH} 1$ & 27588 & 28786 & 1.0 \\
\hline HC-S191-S6-1 & $\mathrm{CH} 1$ & 18430 & 16233 & 0.9 \\
\hline HC-S191-ybbR-1 & $\mathrm{CH} 1$ & 21971 & 25264 & 1.1 \\
\hline HC-S192-A1-1 & $\mathrm{CH} 1$ & 27124 & 24221 & 0.9 \\
\hline HC-S192-S6-1 & $\mathrm{CH} 1$ & 21492 & 20712 & 1.0 \\
\hline HC-S192-ybbR-1 & $\mathrm{CH} 1$ & 25220 & 27786 & 1.1 \\
\hline HC-L193-S6-1 & $\mathrm{CH} 1$ & 11094 & 9327 & 0.8 \\
\hline HC-G194-A1-1 & $\mathrm{CH} 1$ & 23858 & 27185 & 1.1 \\
\hline HC-G194-S6-1 & $\mathrm{CH} 1$ & 20702 & 18593 & 0.9 \\
\hline HC-G194-ybbR-1 & $\mathrm{CH} 1$ & 20659 & 21603 & 1.0 \\
\hline HC-T195-A1-1 & $\mathrm{CH} 1$ & 19614 & 24808 & 1.3 \\
\hline HC-T195-S6-1 & $\mathrm{CH} 1$ & 16083 & 17465 & 1.1 \\
\hline HC-T195-ybbR-1 & $\mathrm{CH} 1$ & 23422 & 25475 & 1.1 \\
\hline HC-Q196-S6-1 & $\mathrm{CH} 1$ & 19695 & 19974 & 1.0 \\
\hline HC-Q196-ybbR-1 & $\mathrm{CH} 1$ & 20702 & 24082 & 1.2 \\
\hline HC-P206-S6-1 & $\mathrm{CH} 1$ & 4400 & 4433 & 1.0 \\
\hline HC-A231-S6-1 & $\mathrm{CH} 2$ & 18890 & 18982 & 1.0 \\
\hline HC-E233-S6-1 & $\mathrm{CH} 2$ & 1066 & 1365 & 1.3 \\
\hline HC-L235-S6-1 & $\mathrm{CH} 2$ & 15932 & 15515 & 1.0 \\
\hline HC-L235-ybbR-1 & $\mathrm{CH} 2$ & 24430 & 27937 & 1.1 \\
\hline
\end{tabular}




\begin{tabular}{|c|c|c|c|c|}
\hline $\begin{array}{l}\text { Antibody/ADC } \\
\text { name }^{a}\end{array}$ & $\begin{array}{l}\text { Antibody domain with } \\
\text { peptide tag insertion }\end{array}$ & $\begin{array}{l}\text { AUC }{ }^{b} h l g G \\
\left(n M^{\star} h\right)\end{array}$ & 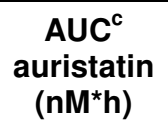 & $\begin{array}{l}\text { AUC(auristatin)/ } \\
\text { AUC(hlgG) }\end{array}$ \\
\hline HC-G236-ybbR-1 & $\mathrm{CH} 2$ & 14771 & 16398 & 1.1 \\
\hline HC-I253-S6-1 & $\mathrm{CH} 2$ & 3203 & 2996 & 0.9 \\
\hline HC-S254-S6-1 & $\mathrm{CH} 2$ & 1609 & 1872 & 1.2 \\
\hline HC-S254-ybbR-1 & $\mathrm{CH} 2$ & 2447 & 2783 & 1.1 \\
\hline HC-R255-S6-1 & $\mathrm{CH} 2$ & 5657 & 6480 & 1.1 \\
\hline HC-R255-ybbR-1 & $\mathrm{CH} 2$ & 2435 & 2514 & 1.0 \\
\hline HC-P257-ybbR-1 & $\mathrm{CH} 2$ & 3036 & 2834 & 0.9 \\
\hline HC-S267-S6-1 & $\mathrm{CH} 2$ & 2481 & 2631 & 1.1 \\
\hline HC-H268-S6-1 & $\mathrm{CH} 2$ & 1916 & 1927 & 1.0 \\
\hline HC-E269-ybbR-1 & $\mathrm{CH} 2$ & 7133 & 9534 & 1.3 \\
\hline HC-D270-S6-1 & $\mathrm{CH} 2$ & 2566 & 2414 & 0.9 \\
\hline HC-D270-ybbR-1 & $\mathrm{CH} 2$ & 12472 & 14013 & 1.1 \\
\hline HC-P271-S6-1 & $\mathrm{CH} 2$ & 1757 & 1550 & 0.9 \\
\hline HC-P271-ybbR-1 & $\mathrm{CH} 2$ & 6651 & 7233 & 1.1 \\
\hline HC-P291-S6-1 & $\mathrm{CH} 2$ & 23692 & 29456 & 1.2 \\
\hline HC-L328-ybbR-1 & $\mathrm{CH} 2$ & 7590 & 8039 & 1.1 \\
\hline HC-A330-S6-1 & $\mathrm{CH} 2$ & 1362 & 1768 & 1.3 \\
\hline HC-A330-ybbR-1 & $\mathrm{CH} 2$ & 12960 & 14302 & 1.1 \\
\hline HC-K340-S6-1 & $\mathrm{CH} 2$ & 17396 & 16060 & 0.9 \\
\hline HC-G341-S6-1 & $\mathrm{CH} 3$ & 9214 & 10336 & 1.1 \\
\hline HC-P343-S6-1 & $\mathrm{CH} 3$ & 16217 & 17009 & 1.0 \\
\hline HC-P343-ybbR-1 & $\mathrm{CH} 3$ & 18942 & 22948 & 1.2 \\
\hline HC-R344-S6-1 & $\mathrm{CH} 3$ & 15196 & 16061 & 1.1 \\
\hline HC-R344-ybbR-1 & $\mathrm{CH} 3$ & 16731 & 19050 & 1.1 \\
\hline HC-K360-S6-1 & $\mathrm{CH} 3$ & 7867 & 8209 & 1.0 \\
\hline HC-E388-S6-1 & $\mathrm{CH} 3$ & 14224 & 14887 & 1.0 \\
\hline HC-E388-ybbR-1 & $\mathrm{CH} 3$ & 21023 & 21257 & 1.0 \\
\hline HC-N389-ybbR-1 & $\mathrm{CH} 3$ & 14601 & 12363 & 0.8 \\
\hline HC-R416-S6-1 & $\mathrm{CH} 3$ & 15181 & 18255 & 1.2 \\
\hline HC-R416-ybbR-1 & $\mathrm{CH} 3$ & 20158 & 21424 & 1.1 \\
\hline HC-Q418-S6-1 & $\mathrm{CH} 3$ & 8561 & 6136 & 0.7 \\
\hline HC-G420-ybbR-1 & $\mathrm{CH} 3$ & 32553 & 34202 & 1.1 \\
\hline HC-N421-ybbR-1 & $\mathrm{CH} 3$ & 13396 & 11255 & 0.8 \\
\hline HC-N434-S6-1 & $\mathrm{CH} 3$ & 2378 & 2249 & 0.9 \\
\hline HC-P445-S6-1 & $\mathrm{CH} 3$ & 28334 & 24130 & 0.9 \\
\hline HC-G446-ybbR-1 & $\mathrm{CH} 3$ & 20329 & 16452 & 0.8 \\
\hline LC-A111-S6-1 & $C_{L}$ & 21011 & 20711 & 1.0 \\
\hline LC-A111-ybbR-1 & $\mathrm{C}_{\mathrm{L}}$ & 16092 & 16196 & 1.0 \\
\hline LC-A153-S6-1 & $\mathrm{C}_{\mathrm{L}}$ & 22890 & 25331 & 1.1 \\
\hline
\end{tabular}




\begin{tabular}{|c|c|c|c|c|}
\hline $\begin{array}{c}\text { Antibody/ADC } \\
\text { name }^{\mathbf{a}}\end{array}$ & $\begin{array}{c}\text { Antibody domain with } \\
\text { peptide tag insertion }\end{array}$ & $\begin{array}{c}\mathbf{A U C}^{\mathbf{b}} \mathbf{h l g G} \\
\left(\mathbf{n M}^{*} \mathbf{h}\right)\end{array}$ & $\begin{array}{c}\mathbf{A U C}^{\mathbf{c}} \\
\text { auristatin } \\
\left(\mathbf{n M}^{*} \mathbf{h}\right)\end{array}$ & $\begin{array}{c}\text { AUC(auristatin)/ } \\
\mathbf{A U C}(\mathbf{h l g G})\end{array}$ \\
\hline LC-A153-ybbR-1 & $\mathrm{C}_{\mathrm{L}}$ & 18406 & 19496 & 1.1 \\
\hline LC-E161-S6-1 & $\mathrm{C}_{\mathrm{L}}$ & 12619 & 11248 & 0.9 \\
\hline LC-K207-S6-1 & $\mathrm{C}_{\mathrm{L}}$ & 12179 & 10699 & 0.9 \\
\hline LC-L154-S6-1 & $\mathrm{C}_{\mathrm{L}}$ & 12426 & 9947 & 0.8 \\
\hline LC-L201-ybbR-1 & $\mathrm{C}_{\mathrm{L}}$ & 17223 & 15036 & 0.9 \\
\hline LC-Q155-S6-1 & $\mathrm{C}_{\mathrm{L}}$ & 15444 & 17657 & 1.1 \\
\hline LC-Q155-ybbR-1 & $\mathrm{C}_{\mathrm{L}}$ & 20100 & 25502 & 1.3 \\
\hline LC-Q199-S6-1 & $\mathrm{C}_{\mathrm{L}}$ & 16832 & 17973 & 1.1 \\
\hline LC-S162-S6-1 & $\mathrm{C}_{\mathrm{L}}$ & 11348 & 11645 & 1.0 \\
\hline LC-S202-ybbR-1 & $\mathrm{C}_{\mathrm{L}}$ & 14938 & 13791 & 0.9 \\
\hline LC-S203-S6-1 & $\mathrm{C}_{\mathrm{L}}$ & 26363 & 31434 & 1.2 \\
\hline LC-S203-ybbR-1 & $\mathrm{C}_{\mathrm{L}}$ & 18663 & 19769 & 1.1 \\
\hline LC-T109-A1-1 & $\mathrm{C}_{\mathrm{L}}$ & 21940 & 19449 & 0.9 \\
\hline LC-V110-A1-1 & $\mathrm{C}_{\mathrm{L}}$ & 16772 & 21425 & 1.3 \\
\hline LC-V110-S6-1 & $\mathrm{C}_{\mathrm{L}}$ & 17358 & 18734 & 1.1 \\
\hline LC-V110-ybbR-1 & $\mathrm{C}_{\mathrm{L}}$ & 20373 & 24757 & 1.2 \\
\hline
\end{tabular}

${ }^{a} \mathrm{~S} 6, \mathrm{ybbR}$, and A1 peptide tags are inserted after the specified residue whose position is labeled according to the Eu numbering system. ${ }^{7}$

${ }^{\mathrm{b}}$ Area-under-the-curve (AUC) as determined by anti-human IgG ELISA.

${ }^{\mathrm{c}} \mathrm{AUC}$ as determined by anti-auristatin ELISA.

n.d., not determined.

$\mathrm{N} / \mathrm{A}$, not applicable. 
Table S6. Mass spectrometric analysis of mAb2 IgG1-HC-E388-ybbR-2 purified from terminal bleed serum. The structure of auristatin-CoA analog 2 (see section 3.2) differs from compound 1 in that the maleimidocaproyl linker is replaced with a maleimidohexyl linker. According to RP-HPLC analysis, the initial DAR of mAb2 IgG1-HC-E388-ybbR-2 was 2.0. The ADC was injected into tumor bearing mice at a single dose of $10 \mathrm{mg} / \mathrm{kg}$. Serum samples were collected after 14 days. Subsequent affinity purification and mass spectrometric analysis of mAb2 IgG1-HC-E388-ybbR-2 was performed as described in the experimental part of the Supporting Information (section 2.4). ADC drug retention was assessed from two independent mass spectrometric measurements.

\begin{tabular}{|c|c|c|c|c|c|c|c|}
\hline \multicolumn{8}{|c|}{ Experiment 1} \\
\hline Species & $\begin{array}{l}\text { Observed } \\
\text { mass }(D a)^{a}\end{array}$ & $\begin{array}{c}\text { Observed } \Delta \\
\text { mass }(D a)^{b}\end{array}$ & $\begin{array}{c}\text { Calculated } \Delta \\
\text { mass }(D a)^{c}\end{array}$ & $\begin{array}{c}\text { Peak } \\
\text { intensity }\end{array}$ & $\begin{array}{l}\text { Conjugate } \\
\text { ratio of } \\
\text { heavy } \\
\text { chain }\end{array}$ & DAR & $\begin{array}{c}\% \text { DAR } \\
\text { retention }\end{array}$ \\
\hline $\begin{array}{l}\text { Phosphopantethein } \\
\text { ylated heavy chain }\end{array}$ & 51718 & 339 & 340 & 243607 & \multirow{3}{*}{0.84} & \multirow{3}{*}{1.7} & \multirow{3}{*}{84} \\
\hline $\begin{array}{l}\text { Drug-conjugated } \\
\text { heavy chain }^{f}\end{array}$ & 52629 & 1250 & 1252 & 720535 & & & \\
\hline $\begin{array}{c}\text { Drug-conjugated } \\
\text { heavy chain, } \\
\text { hydrolyzed }^{g}\end{array}$ & 52648 & 1269 & 1270 & 555870 & & & \\
\hline \multicolumn{8}{|c|}{ Experiment 2} \\
\hline Species & $\begin{array}{l}\text { Observed } \\
\text { mass }(D a)^{a}\end{array}$ & $\begin{array}{c}\text { Observed } \Delta \\
\text { mass }(D a)^{b}\end{array}$ & $\begin{array}{c}\text { Calculated } \Delta \\
\text { mass }(D a)^{c}\end{array}$ & $\begin{array}{c}\text { Peak } \\
\text { intensity }\end{array}$ & $\begin{array}{l}\text { Conjugate } \\
\text { ratio of } \\
\text { heavy } \\
\text { chain }\end{array}$ & DAR & $\begin{array}{l}\% \text { DAR } \\
\text { retention }\end{array}$ \\
\hline $\begin{array}{l}\text { Phosphopantethein } \\
\text { ylated heavy chain }\end{array}$ & 51716 & 337 & 340 & 233070 & \multirow{3}{*}{0.84} & \multirow{3}{*}{1.7} & \multirow{3}{*}{84} \\
\hline $\begin{array}{l}\text { Drug-conjugated } \\
\text { heavy chain }^{f}\end{array}$ & 52628 & 1249 & 1252 & 680520 & & & \\
\hline $\begin{array}{c}\text { Drug-conjugated } \\
\text { heavy chain, } \\
\text { hydrolyzed }^{g}\end{array}$ & 52647 & 1268 & 1270 & 529047 & & & \\
\hline
\end{tabular}

${ }^{a}$ Observed masses correspond to distinct conjugation states of the non-deglycosylated heavy chain of mAb2 IgG1-HC-E388-ybbR antibody.

${ }^{\mathrm{b}}$ Observed $\Delta$ mass refers to the deviation of the observed mass of each conjugation state from that of the non-conjugated heavy chain (51379 Da).

${ }^{\mathrm{c}}$ Calculated $\Delta$ mass according to ChemBioDraw Ultra (version 12.0).

${ }^{d}$ Conjugate ratio of heavy chain refers to the quotient between the peak intensities of drug-conjugated heavy chain (hydrolyzed and non-hydrolyzed) and phosphopantetheinylated heavy chain.

${ }^{\text {e }}$ Drug deconjugation due to cleavage of thiosuccinimide linkage.

${ }^{f}$ ADC drug-linker contains non-hydrolyzed thiosuccinimide linkage.

${ }^{\mathrm{g}} \mathrm{ADC}$ drug-linker contains hydrolyzed thiosuccinimide linkage. 


\section{References}

(1) Grunewald, J.; Jones, D. H.; Brock, A.; Chiu, H. P.; Bursulaya, B.; Ng, K.; Vo, T.; Patterson, P.; Uno, T.; Hunt, J.; Spraggon, G.; Geierstanger, B. H. Chembiochem : a European journal of chemical biology 2014, 15, 1787.

(2) Carter, P.; Presta, L.; Gorman, C. M.; Ridgway, J. B.; Henner, D.; Wong, W. L.; Rowland, A. M.; Kotts, C.; Carver, M. E.; Shepard, H. M. Proceedings of the National Academy of Sciences of the United States of America 1992, 89, 4285.

(3) Klock, H. E.; Koesema, E. J.; Knuth, M. W.; Lesley, S. A. Proteins 2008, 71, 982.

(4) Ou, W.; Uno, T.; Chiu, H. P.; Grunewald, J.; Cellitti, S. E.; Crossgrove, T.; Hao, X.; Fan, Q.; Quinn, L. L.; Patterson, P.; Okach, L.; Jones, D. H.; Lesley, S. A.; Brock, A.; Geierstanger, B. H. Proceedings of the National Academy of Sciences of the United States of America 2011, 108, 10437.

(5) Gonzalez, R.; Jennings, L. L.; Knuth, M.; Orth, A. P.; Klock, H. E.; Ou, W.; Feuerhelm, J.; Hull, M. V.; Koesema, E.; Wang, Y.; Zhang, J.; Wu, C.; Cho, C. Y.; Su, A. I.; Batalov, S.; Chen, H.; Johnson, K.; Laffitte, B.; Nguyen, D. G.; Snyder, E. Y.; Schultz, P. G.; Harris, J. L.; Lesley, S. A. Proceedings of the National Academy of Sciences of the United States of America 2010, 107, 3552.

(6) Doronina, S. O.; Mendelsohn, B. A.; Bovee, T. D.; Cerveny, C. G.; Alley, S. C.; Meyer, D. L.; Oflazoglu, E.; Toki, B. E.; Sanderson, R. J.; Zabinski, R. F.; Wahl, A. F.; Senter, P. D. Bioconjugate chemistry 2006, 17, 114.

(7) Edelman, G. M.; Cunningham, B. A.; Gall, W. E.; Gottlieb, P. D.; Rutishauser, U.; Waxdal, M. J. Proceedings of the National Academy of Sciences of the United States of America 1969, 63, 78. 